\title{
AN INTERVENTIONAL INFORMATICS APPROACH TO DEVELOPMENT AND EVALUATION OF POPULATION-BASED HEALTH AND WEB TECHNOLOGIES
}

\author{
A Dissertation \\ presented to
}

the Faculty of the Graduate School

at the University of Missouri-Columbia

$$
\begin{aligned}
& \text { In Partial Fulfillment } \\
& \text { of the Requirements for the Degree } \\
& \text { Doctor of Philosophy, Informatics - Health Informatics }
\end{aligned}
$$

By

DIANA R. KENNEDY

Dr. Suzanne A. Boren, Dissertation Supervisor

DECEMBER 2017 


\section{APPROVAL PAGE}

The undersigned, appointed by the dean of the Graduate School, have examined the dissertation entitled

AN I NTERVENTIONAL INFORMATICS APPROACH TO

DEVELOPMENT AND EVALUATION OF POPULATION-BASED HEALTH AND WEB TECHNOLOGIES presented by Diana Kennedy

a candidate for the degree of doctor of philosophy and hereby certify that, in their opinion, it is worthy of acceptance.

Suzanne A. Boren, PhD, MHA, Adviser

David Fleming, MD, MA, Center for Health Ethics

Lanis Hicks, PhD, Health Management and Informatics

Win Phillips, PhD, Health Management and Informatics 
To my darling Noah, for your unending support of my educational

pursuit. I wish for your dreams to be big, your heart to be full, and your journey to be gratifying. 


\section{ACKNOWLEDGEMENTS}

Without the encouragement of my colleagues, professors, family, and friends my journey through this doctoral program could not have been accomplished. I am eternally grateful for the infusion of knowledge, inspiration, guidance, support, and wisdom I have received. I yearn to pay it forward to improve the health status of vulnerable populations and communities.

This dissertation was profoundly impacted by the late Dr. Isaac Clark Davis and Mrs. Dorothy Davis for their great impact on my academic strive and growing seeds of interest in my end-of-life care planning research. 


\section{TABLE OF CONTENTS}

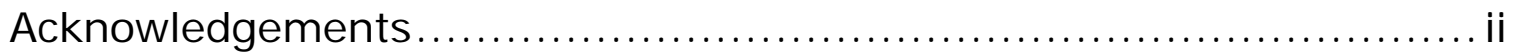

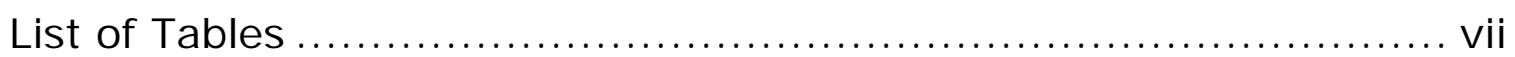

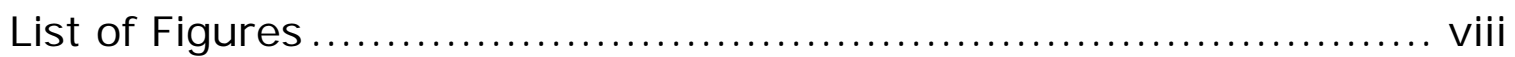

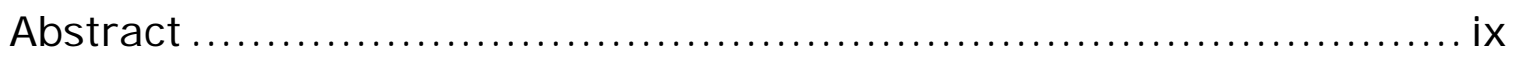

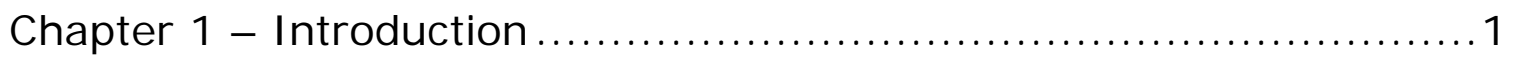

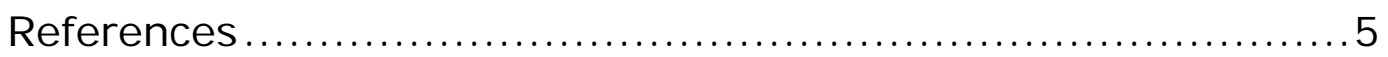

Chapter 2 - Building and Launching an Online Quality Improvement Information Exchange for Home Visiting Programs in Missouri .........6

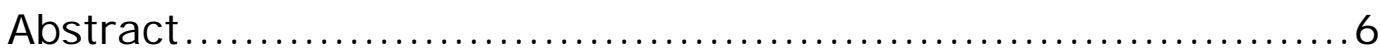

Introduction \& Implications for Policy and Practice ............... 9

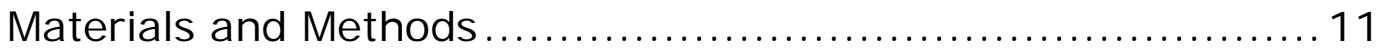

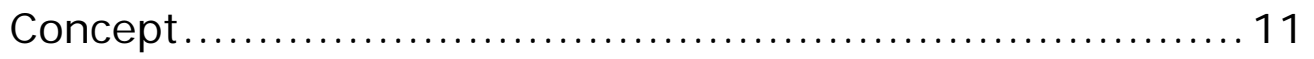

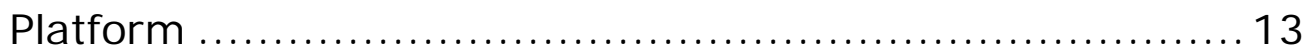

Information Exchange Infrastructure and Development .... 15

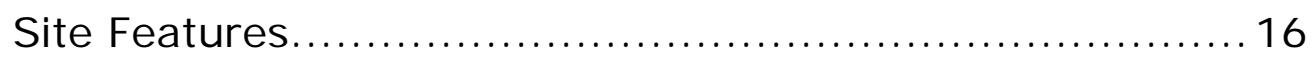

User Engagement \& Social Media ............................ 23

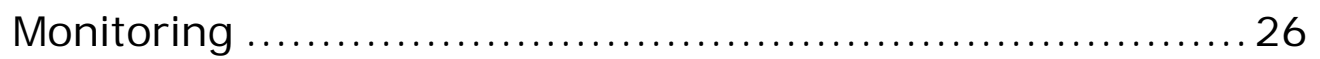




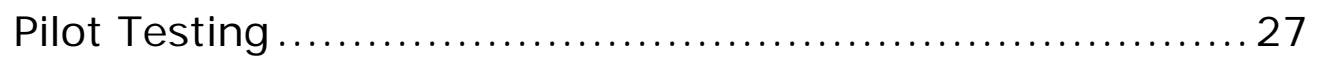

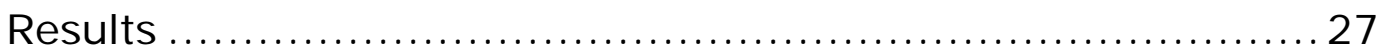

Pilot Testing Results ...................................... 27

Site Launch \& Results..................................... 34

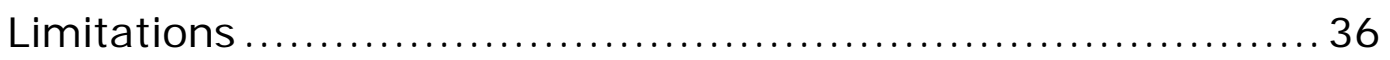

Discussion $\&$ Conclusion ....................................... 37

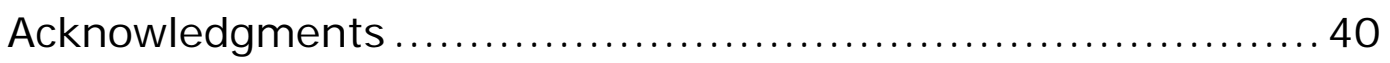

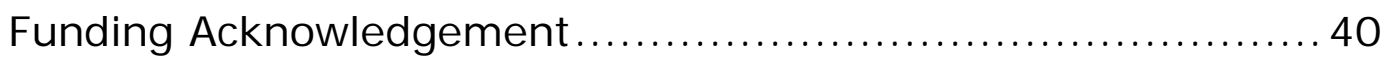

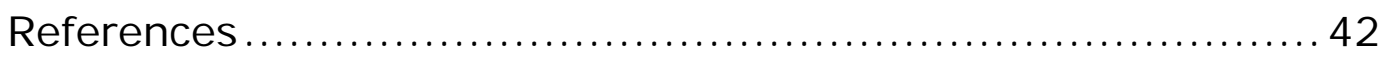

Chapter 3 - Psychometric Properties of Patient-Facing eHealth Evaluation Measures: Systematic Review and Analysis ............... 45

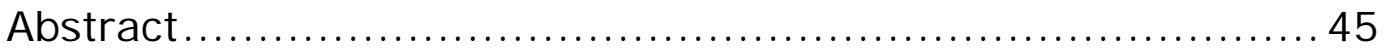

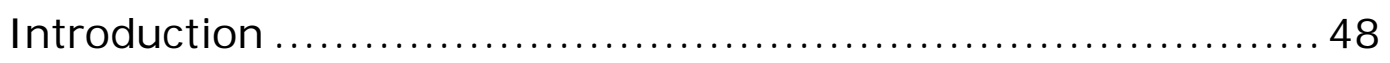

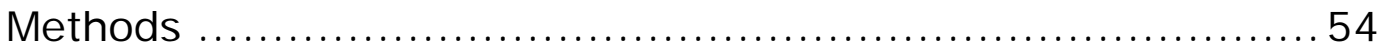

Identification of Search Terms ............................. 54

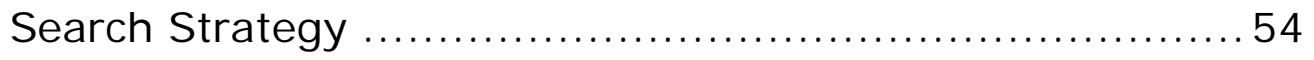

Inclusion Criteria ......................................... 55

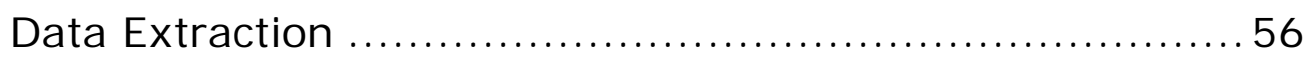

iv 
Results 60

Discussion 68

Principal Findings. 68

Limitations 71

Conclusions 71

Acknowledgments 73

Abbreviations 75

References 76

Chapter 4 - State of Advance Care Planning and Provider Usability of

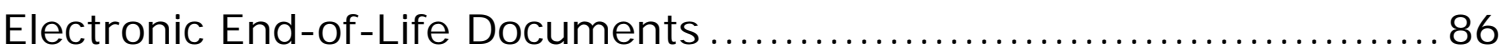

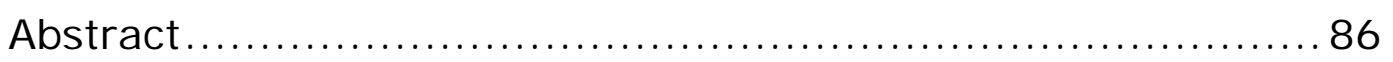

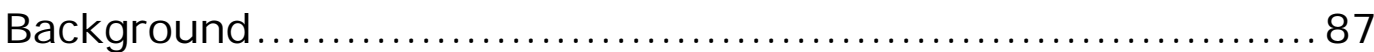

History of Advance Care Planning .......................... 90

Health Economics and an Aging Population ................. 92

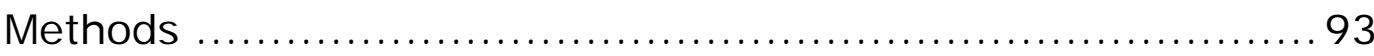

Results and Discussion ....................................... 94

Conclusion and Future Directions ............................. 97

Computer Decision-Aid .................................. 97 
Future Skills to be Gained ................................ 99

Definition of Terms.......................................... 101

References................................................... 103

Chapter 5 - Conclusion .......................................... 108

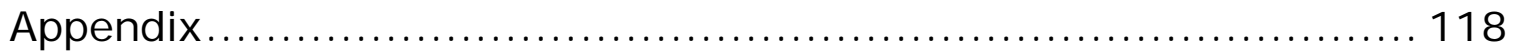

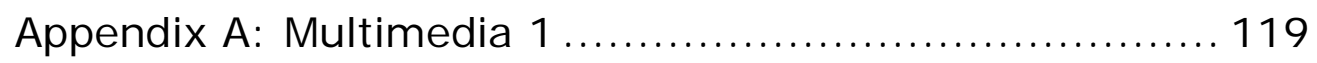

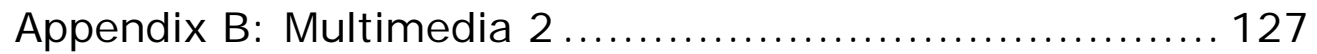

Appendix C: Provider Questionnaire ...................... 148

Appendix D: Consent and Recruitment Email for "Providers

Survey on Advance Care Directives" Survey............... 153

Appendix E: Institutional Review Board Approval .......... 154

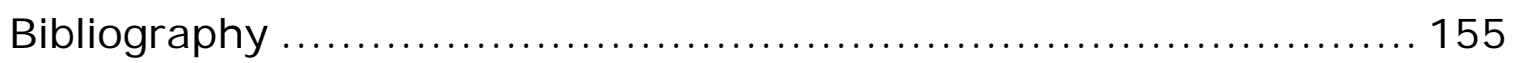

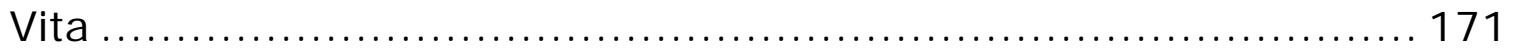




\section{LIST OF TABLES}

\section{CHAPTER TWO}

Table 1, Pilot Usability Testing Results ......................... 28

Table 2, Modified System Usability Scale Survey ................. 29

Table 3, Program Fidelity \& CQI Assessment Evaluation Survey

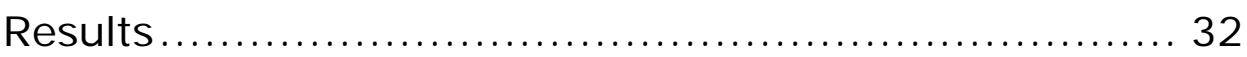

\section{CHAPTER THREE}

Table 1, Data Extraction Elements

Table 2, Concepts 1 to 6 Identified in Reviewed Instruments

$$
(\mathrm{N}=23)
$$

Table 3, Concepts 7 to 12 Identified in Reviewed Instruments

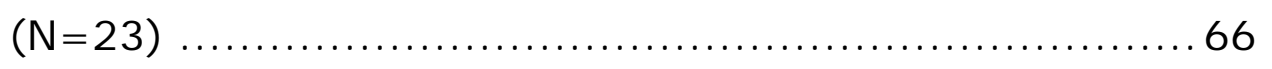

\section{CHAPTER FOUR}

Table 1, Barriers to Advance Directive Utilization 


\section{LIST OF FI GURES}

\section{CHAPTER TWO}

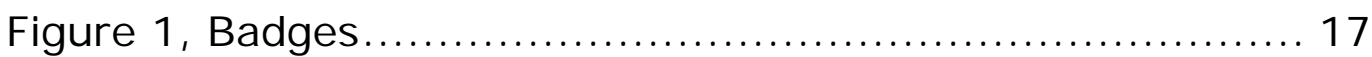

Figure 2, Current CQI Project Tracker screenshot............... 20

Figure 3, Training page screenshot........................... 22

Figure 4, MIECHV Gateway Site Metrics Dashboard, September

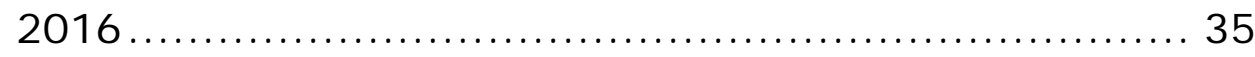

\section{CHAPTER THREE}

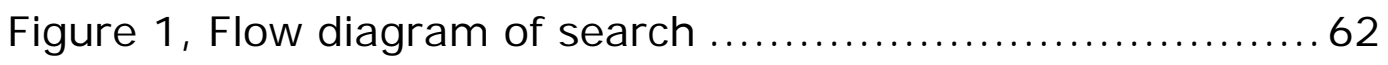




\section{ABSTRACT}

Interventional informatics is the use of health information technology (HIT) that drives evidence-based and evidence-generating practices to inform an improved health delivery system. Current HIT lacks movement towards data-driven infrastructures designed to promote information gathering, sharing, and new knowledge discovery in several areas. This thesis undertakes three specific areas where gaps exist. First, in undertaking quality improvement initiatives aligned with fidelity to program models, a web-based practice exchange was designed, built, tested and launched. Second, a systematic review of eHealth technology instruments for outcomes and evaluation components geared towards patient outcomes was conducted, uncovering gaps in the availability of psychometrically sound measures to evaluate eHealth technologies. Third, a study was conducted to establish a baseline of satisfaction and usability among medical care providers with the current advance care planning process (ACP) and documentation within the electronic medical record (EMR). This study discovered barriers to use of the EMR to retrieve ACP documents and prioritization areas for improvements to begin. 


\section{CHAPTER 1 - I NTRODUCTI ON}

Interventional informatics is an emerging specialty within health informatics. Interventional informatics is "an approach in the use of health information technology in a manner that improves clinical decision-making, care delivery processes and/or population health strategies while simultaneously enabling systematic evidence generation through routine practice" [1]. This approach enables health information professionals to apply data-driven innovations focused on generating unique evidence-gathering approaches, which contribute to the coordination and delivery of health care and the management and insight of population health.

This thesis contains a culmination of research within the field of health informatics aimed at producing innovations and knowledge. This aim is achieved through research geared towards understanding the opportunities, barriers, application, innovation, and outcomes of health information technology (HIT) and health informatics research.

First, the "Building and Launching an Online Quality Improvement Information Exchange for Home Visiting Programs in Missouri" chapter was published in the Online Journal of Public Health Informatics [2]. This manuscript describes the characteristics, 
development, build, and launch of a quality improvement practice exchange virtual environment for use by home visiting agencies in Missouri and present results of three usability pilot tests and the site launch.

Second, chapter three entitled "Psychometric Properties of Patient-Facing eHealth Evaluation Measures: Systematic Review and Analysis" is a systematic literature review and analysis published in the Journal of Medical Internet Research [3]. This manuscript reviews eHealth technology instruments for outcomes and evaluation components geared towards patient outcomes. The objective of this systematic review aimed to (1) identify existing instruments for eHealth research and implementation evaluation from the patient's point of view, (2) characterize measurement components, and (3) assess psychometrics. Through this review, we identified 23 articles for inclusion in the review, none of which included a complete psychometric evaluation. This review highlights important gaps in the availability of psychometrically sound measures to evaluate eHealth technologies.

Third, the "State of Advance Care Planning and Provider Usability of Electronic End-of-Life Documents" chapter describes (1) a brief 
history of advance care planning (ACP) in the United States (U.S.), (2) the current state of ACP in the U.S., (3) presents results of a health provider survey that identified barriers to utilization of end-of-life care preference documents stored in the electronic medical record (EMR), and (4) presents results of a health provider survey that identified prioritization areas where improvements to the EMR technology, clinical workflow and process, and the delivery of education to both providers and patients should be made. The provider survey found that the current HIT lacks movement towards an infrastructure of capturing patient preferences that can potentially translate to medical decision-making in end-of-life care. This chapter presents gaps in the body of medical and bioethics research, which include the adoption of a public good aimed at defining users' unique preferences and wishes at multiple points in time, and through life stages, which would inform the medical care workflow. This adherence to patient choice and increased effectiveness from informative documentation support the innovation of providing individualized healthcare, specifically at and near the end of life. The chapter highlights areas where research has the potential to directly impact public health with the delivery of an innovative approach to the reinvention of the ACP activity. 
In summary, the main contribution of this research to the field of health informatics is garnered from its willingness to examine traditional pathways for knowledge discovery and when applied, innovative technologies to better understand user-adoption, utility, usability and feasibility of these technologies and the outcomes of exposure to the technologies. 


\section{References}

1. Payne PR, Lussier Y, Foraker RE, Embi PJ. Rethinking the role and impact of health information technology: informatics as an interventional discipline. BMC Med Inform Decis Mak. 2016 Mar 29; 16: 40. doi: 10.1186/s12911-016-0278-3. Review. PubMed PMID: 27025583; PubMed Central PMCID: PMC4812636.

2. Kennedy DR, Boren SA, Kapp JM, Simoes EJ. Building and launching an online quality improvement information exchange for home visiting programs in Missouri. Online Journal of Public Health Informatics. 2017 Sep 8; 9(2).

3. Wakefield BJ, Turvey CL, Nazi KM, Holman JE, Hogan TP, Shimada SL, Kennedy DR. Psychometric Properties of PatientFacing eHealth Evaluation Measures: Systematic Review and Analysis. J ournal of Medical Internet Research. 2017 Oct; 19(10). 


\section{CHAPTER 2 - BUI LDI NG AND LAUNCHI NG AN}

ONLI NE QUALITY I MPROVEMENT

\section{NFORMATI ON EXCHANGE FOR HOME VI SI TI NG PROGRAMS I N MISSOURI}

Diana R. Kennedy, MHA, MSHI ${ }^{1,2}$, Suzanne A. Boren, $\mathrm{PHD}, \mathrm{MHA}^{1,2}$, Julie M. Kapp, MPH, $\mathrm{PHD}^{1}$, Eduardo J. Simoes, MD, MSc, MPH ${ }^{1,2}$

${ }^{1}$ Department of Health Management and Informatics, University of Missouri, Columbia, Missouri, USA

2 MU Informatics Institute, University of Missouri, Columbia, Missouri, USA

\section{Abstract}

BACKGROUND: Continuous quality improvement initiatives (CQII) in home visiting programs have traditionally occurred within a local implementing agency (LIA), parent organization, or funding provision. In Missouri, certain LIAs participate in the Missouri Maternal, Infant, and Early Childhood Home Visiting program (MIECHV). Their CQII activities and the coordination of CQI efforts across agencies are limited to quarterly meetings to discuss barriers to service delivery and newsletters. Their designed CQI process does not include evaluation of 
program fidelity or assessment nor supports to assist with identifying and prioritizing areas where improvement is needed. Therefore, much of LIA CQII are often lost to the benefit of external agencies facing similar challenges. OBJECTIVES: We developed a virtual environment, the Missouri MIECHV Gateway, for CQII activities. The Gateway promotes and supports quality improvement for LIAs while aligning stakeholders from seven home visiting LIAs. Development of the Gateway environment aims to complement the existing MIECHV CQI framework by: 1) adding CQI elements that are missing or ineffective, 2) adding elements for CQI identification and program evaluation, and 3) offering LIAs a network to share CQI experiences and collaborate at a distance. This web-based environment allows LIA personnel to identify program activities in need of quality improvement, and guides the planning, implementation, and evaluation of CQII. In addition, the Gateway standardizes quality improvement training, collates overlapping resources, and supports knowledge translation, thus aimed to improve capacity for measurable change in organizational initiatives. RESULTS: Briefly, prior to deployment to 58 users, usability pilot testing of the site occurred in three stages, to three defined groups. Pilot testing results were overall positive, desirable, and vital 
to improving the site prior to the full-launch. The majority of reviewers stated they would access and use the learning materials ( $87 \%$ ), use the site for completing CQII (80\%), and reported that the site will benefit their work teams in addressing agency challenges (66\%). The majority of reviewers also approved of the developed fidelity assessment: as, easy to use (79\%), having a clear purpose ( $86 \%)$, providing value in self- identification of CQII (75\%), and recommendations were appropriate (79\%). The System Usability Scale (SUS) score increased (10\%) between pilot groups 2 and 3, with a mean SUS score of 71.6 , above the U.S. average of 68 . The site launched to 60 invited users; the majority (67\%) adopted and used the site. Site stability was remarkable ( 6 total minutes of downtime). The site averaged 29 page views per day. DISCUSSION: This article describes the characteristics, development, build, and launch of this quality improvement practice exchange virtual environment and present results of three usability pilot tests and the site launch. This interactive web-based portal provides the infrastructure to virtually connect and engage LIAs in CQI and stimulate sharing of ideas and best practices. 
Keywords: continuous quality improvement, online, public health, home visiting programs, training, information exchange, capacity building.

\section{Introduction \& I mplications for Policy and Practice}

Early childhood home visiting programs date back to the $1880 \mathrm{~s}$ and deliver a vital public service of providing and connecting families with health, educational, and economic resources to support optimal development [1]. The home visitor service delivery model provides intervention and mediation techniques to families with young children [1]. Presently, seven local implementing agencies (LIA) in Missouri are participating in the Missouri Department of Health and Senior Services (MoDHSS) Maternal, Infant, and Early Childhood Home Visiting program ( MIECHV). The LIAs coordinate continuous quality improvement initiatives (CQII) as part of a MoDHSS contract deliverable and, potentially, as required by their accrediting model. LIAs adhere to a designed continuous quality improvement (CQI) process focused on broad programmatic strategies. The MIECHV program evaluation found the direction and coordination of CQI efforts across agencies were limited to quarterly meetings and newsletters. The evaluation also found a lack of past or present documented CQII. 
In addition, the MIECHV CQI process did not include: an evaluation of program fidelity, an identification and prioritization of problems with program implementation, the development and execution of corrective action plans to address shortfalls, and an avenue to disseminate CQI experiences. Without dissemination of CQI experiences, CQII are often lost to the benefit of external agencies facing similar challenges. Overall, the program evaluation suggested the need to provide more structured CQI supports to enable LIAs to self-administer and direct their improvement activities, independently from the broader MoDHSS-driven MIECHV CQII activities. In addition, the evaluation suggested the need to enhance participating LIAs' communication networks to foster connecting, sharing, collaborating, and learning across LIAs. In response to these program challenges, we developed a quality improvement information exchange web-based environment, the Missouri MIECHV Gateway. The Gateway aims to enhance CQII by providing an infrastructure to self-assess local program activities in need of quality improvement, and to guide the planning, implementation and evaluation of CQII. In addition, the Gateway virtually connects and engages LIAs in CQII by serving as a portal to share CQII, identify best practices, generate new learning, and 
network across agencies to virtually align stakeholders from the seven home visiting LIAs. This web-based environment aims to support current LIA CQII activities, while at the same time, adding missing elements that will strengthen it. We describe the characteristics, development, build, and launch of this quality improvement practice exchange virtual environment and present results of three usability pilot tests and the site launch.

\section{Materials and Methods}

\section{Concept}

Quality improvement consists of systematic and continuous actions that lead to measurable improvement in services for targeted groups [2]. A simple web search of "quality improvement education" returns over 114 million results. The abundant search results demonstrate CQI web-based resources both exist and are publically shared. However the quality, applicability, and validity of these webbased resources must be evaluated on an individual basis. Sifting through those results requires a time commitment many public health agencies cannot afford and is likely overwhelming to the average user seeking basic CQI knowledge. 
A search of existing literature and web resources uncovered an additional gap in the implementation of online quality improvement sites. The literature, however limited, provided insight on characteristics of other project sites. CQI resources, historically used in business and industry environments (e.g., Juran 1951; I shikawa 1985; Deming 1986), were translated to learning materials and tools applicable for the home visiting LIAs. A National Association of County and City Health Officials project reported the most valuable web-based resources as: public health related CQI resources, training, tools, networking, and one-on-one consultation [3]. In a web-based site designed for home visiting programs in Ohio and Kentucky, the integration of user access to quality indicator performance reports increased user downloads by $297 \%$, and a centralized data reporting system improved the program's ability to meet performance indicators and standardize treatment across multiple sites [4].

To enhance CQII and promote sharing across LIAs, we designed and built a web-based portal to provide LIAs the infrastructure to selfassess local program activities in need of quality improvement, and to guide the planning, implementation and evaluation of CQII. In addition, the Missouri MIECHV Gateway virtually connects and engages 
LIAs in CQII by serving as a portal for LIAs to undertake and share CQII, identify best practices, generate new learning, and network across agencies. Knowledge from the literature, paired with expert consultation, substantiated both the usefulness and uniqueness of building and developing the Missouri MIECHV Gateway, a proof-ofconcept website which represents a passage into a quality improvement network.

\section{Platform}

Planning, designing, building, and developing a website is a significant undertaking. Weekly planning sessions occurred for several months before an online environment existed. The website was developed and hosted in the Amazon Web Service (AWS) cloud environment on a standard Windows 2012 platform. AWS was chosen for several reasons: 1) initial low-volume use of a single virtual server in AWS is free for development, allowing for economical and fast initial set-up; 2) as with most cloud hosting services, AWS allows for rapid expansion of capacity in response to use demand; given the novelty of the site and uncertainty as to the ultimate volume of traffic it will generate over the long term, this flexibility is key to meeting future needs; 3) AWS is the largest and most popular cloud hosting system in 
the U.S., so should be familiar to the widest range of future developers and maintainers who might be involved in the project; and 4) the cloud nature of AWS makes it easy to transfer ownership and administrative duties as necessary throughout the indefinite life of the project. The website itself is built within the WordPress CMS platform for several reasons: 1) WordPress is free, open source software; 2) WordPress offers a large library of plugin extensions and one of the largest third-party developer communities in the industry, making it functionally extensible; 3) WordPress is one of the most widely deployed CMS platforms in the world, so should be familiar to the widest range of future developers and maintainers who might be involved in the project, and; 4) WordPress has modest and easily accessible language and database middleware requirements (in our case, PHP and MySQL, respectively), allowing the server operating system to acclimate to most specifications and the site to be highly portable. Once the site was established on the server, a secure HTTP over SSL domain name was registered. 


\section{I nformation Exchange I nfrastructure and Development}

Krug's (2014) book Don't Make Me Think, Revisited has provided valuable insight on website design and usability. Krug encourages adopting expected conventions for web pages including where things are located on a page, how things work, how things look and how primary, secondary, and tertiary menus should be added and arranged [5].

We designed and built the site infrastructure with five main content pages: Home; CQI Process; Discussions; Education \& Training; and Resources. The Home page includes the following secondary pages: About; Getting Started; Feedback; and Technical Support. Under CQI Process, the secondary pages of CQI Process Overview, Current CQI Project Tracker, Stage 1: Plan, Stage 2: Do, Stage 3:

Study, and Stage 4: Act pages are located. The Discussion Forum, Groups, and Members secondary pages are housed under the Discussions primary menu. Events, Glossary, MIECHV, CQI Storyboard Library, Gateway Webinars, and Training are located under Education and Training. The Resources primary menu includes the secondary menu External Resources and Organization Directory pages. 


\section{Site Features}

To exclusively limit site access to LIA and MoDHSS staff, a plugin was enabled to require a username and password to log into the site. This encourages idea sharing and collaboration between the LIAs, without input from the general public. Gateway Administrators established initial accounts with a system-generated strong password. Once users enter the site, they are directed to set a unique password which meets or exceeds strong password standards.

User profile management affords users an identity beyond their username and promotes social networking. A registered user can upload a profile photo, a cover photo, and update information on their public profile such as their job role, professional interests, and other demographic information viewable by all registered users.

To draw users into and around the site, a plan for user engagement was established. This plan incorporated the use of gamification methods. Gamification is the application of incentives typically found in gaming applications to a non-gaming environment. The first gamification method incorporated was the integration of a badge system. When a user completes defined activities within the 
site, a medal shaped icon, referred to as a badge, is awarded to the user and displayed on the user's profile indefinitely (Figure 1).

Figure 1, Badges

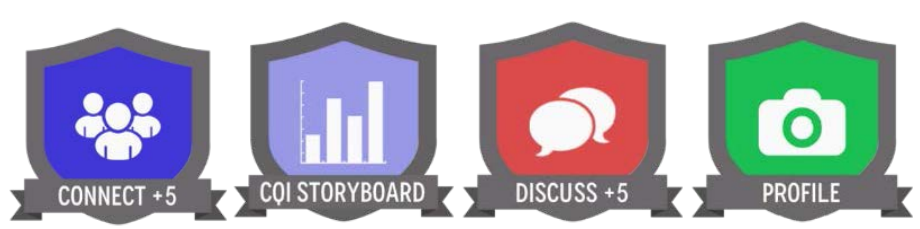

The second incorporated gamification method was the inclusion of a user activity point system. Users who complete activities across the site (e.g., daily login, joining a group, participating in a discussion forum, uploading a storyboard, downloading a tutorial, etc.) receive points based on a defined point system ranging from 1-5 points per activity. There is no maximum number of points a user can accumulate, and users can never lose points. A user's point sum is highlighted on their profile page and in the running footer of the website in a ranked order.

The Home page content includes a quick link meta slider with scrolling images and text of site pages, Getting Started links, a weekly poll, a weekly quote, and a listing of upcoming events. Of note, the weekly poll is designed as a simple yes/no or multiple choice question to inform site development, site satisfaction, and user engagement. Site features under the Home menu are organized in an expected 
arrangement for the average web user. A user guide and Frequently Asked Questions page exist, along with web forms designed for both submitting feedback and seeking technical assistance.

The CQI Process tab houses the process designed to enable LIA users to complete a self-assessment, design and implement a local quality improvement project, evaluate the project, and finalize the project in the format of a CQI storyboard. W. Edwards Deming's PlanDo-Study-Act (PDSA) cycle was integrated as the preferred model to drive continuous small-scale CQI improvements [6]. The storyboard captures all stages of the Plan-Do-Study-Act (Stages 1-4) CQI project, shares lessons learned, and future directions. These storyboards are stored in a searchable directory under the Education and Training tab. Within each stage of the CQI process, guided questions and training tutorials are available to the user. Specifically, within Stage 1: Planning, users begin the CQI process by completing a program fidelity and CQI assessment, a structured survey where the user self-reports the extent to which theoretical model program activities are implemented within their LIA and to the MIECHV program implementation. This assessment provides fidelity score, recommendation, and a document suggestions areas for related 
potential quality improvement activities. A point system is assigned to user responses as 'always implemented' ( 4 points), 'sometimes implemented' [3], 'seldom implemented' [2], 'never implemented' [1], and 'unable to evaluate' (0). These points are summed and divided by the number of questions, excluding those in which 'unable to evaluate' is selected. Scores are then paired with the scoring key; $75 \%$ and above are considered as operating with a high level of fidelity to the model activities. User assessments within this scoring bracket are encouraged to continue ongoing review of program assessment and quality improvement work, as needed, to maintain fidelity. Scores within $30-74 \%$ strongly recommend the user begins quality improvement projects to improve fidelity, and scores within the 1-29\% range recommend users take immediate action in the form of program assessment and quality improvement work to reach a higher level of fidelity. This assessment also captures additional information including the problems with implementation, barriers to implementation, and history of CQI review. Following completion of the assessment, users are guided back to Stage 1 where they begin a CQI project and navigate through to Stage 4. Finally, the CQI Process tab hosts the Current CQI Project Tracker page, which includes an interactive table 
listing of current CQI projects in process (Figure 2). Users add their projects to the public table, update the project status as they progress, and search for current CQI projects of interest.

The Discussions tab houses three pages, Discussion Forum, Groups, and Members. BuddyPress, a popular social network software plugin that integrates open discussion forums, group forums (private and public), and member connections. Within the discussion and group forums, users post and respond to threaded discussions with the ability to upload documents and insert URL hyperlinks. The Discussions sub-page sidebars include activity streams to easily guide users to active discussions and group forums.

Figure 2, Current CQI Project Tracker screenshot

\section{CURRENT PROJECTS}

Below is a listing of current quality improvement projects. Project Leaders and CQI team members are encouraged to update the status of their projects frequently. Use the below form to add a new project to the list. To edit an existing listing, click the "Edit" hyperlink next to the specific project listing.

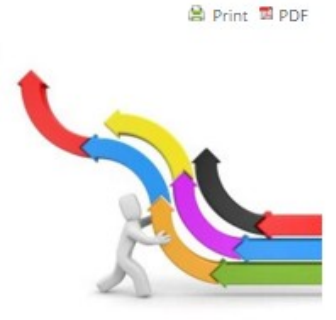

\section{Search Listings}

Show All Listings

\begin{tabular}{|l|l|l|l|l|l|l|}
\hline PROJECT TITLE & AGENC* & $\begin{array}{l}\text { AGENCY } \\
\text { MODEL }\end{array}$ & $\begin{array}{l}\text { PROJECT } \\
\text { LEADER }\end{array}$ & $\begin{array}{l}\text { PROJECT } \\
\text { STATUS }\end{array}$ & $\begin{array}{l}\text { DATE } \\
\text { UPDATED }\end{array}$ & $\begin{array}{l}\text { EDIT } \\
\text { LISTING }\end{array}$ \\
\hline $\begin{array}{l}\text { Increase client } \\
\text { satisfaction survey } \\
\text { participation }\end{array}$ & UMC & $\begin{array}{l}\text { Other: } \\
\text { Example } \\
\text { CQI Project }\end{array}$ & $\begin{array}{l}\text { Gateway } \\
\text { Admin }\end{array}$ & Complete & $04 / 15 / 16$ & Edit \\
\hline $\begin{array}{l}\text { Decrease scheduling } \\
\text { conflicts }\end{array}$ & UMC & $\begin{array}{l}\text { Example } \\
\text { CQI Project }\end{array}$ & $\begin{array}{l}\text { Gateway } \\
\text { Admin }\end{array}$ & Complete & $03 / 31 / 16$ & Edit \\
\hline
\end{tabular}


The Education and Training menu tab includes the following subpages: Events, Glossary, MIECHV, CQI Storyboard Library, Gateway Webinars, and Training. Events includes a menu of offerings, from conferences to awareness weeks with each event tagged to applicable categories. These tags are populated in a word cloud-type format that appears in the footer of all site pages. Any tagged category can be clicked by the user which filters the full site for content with the selected tag, affording a quick and accurate search. The Glossary page includes a comprehensive and alphabetical listing of key CQI terms, definitions, resources, and site training tutorials of frequently used CQI terminology and concepts, designed as a quick reference for user retrieval. The MIECHV page includes program specific documents such as CQI meeting minutes, CQI newsletters, forms, and reports. The CQI Storyboard Library, as previously discussed under the CQI Process menu, includes a search-enabled directory of completed CQI project storyboards. The Gateway Webinars page houses recorded webinar videos, their accompanying slide decks, and announcements for upcoming webinars. Lastly, the Training page hosts meta slider tutorials on common CQI tools and methodologies (Figure 3). 
Figure 3, Training page screenshot

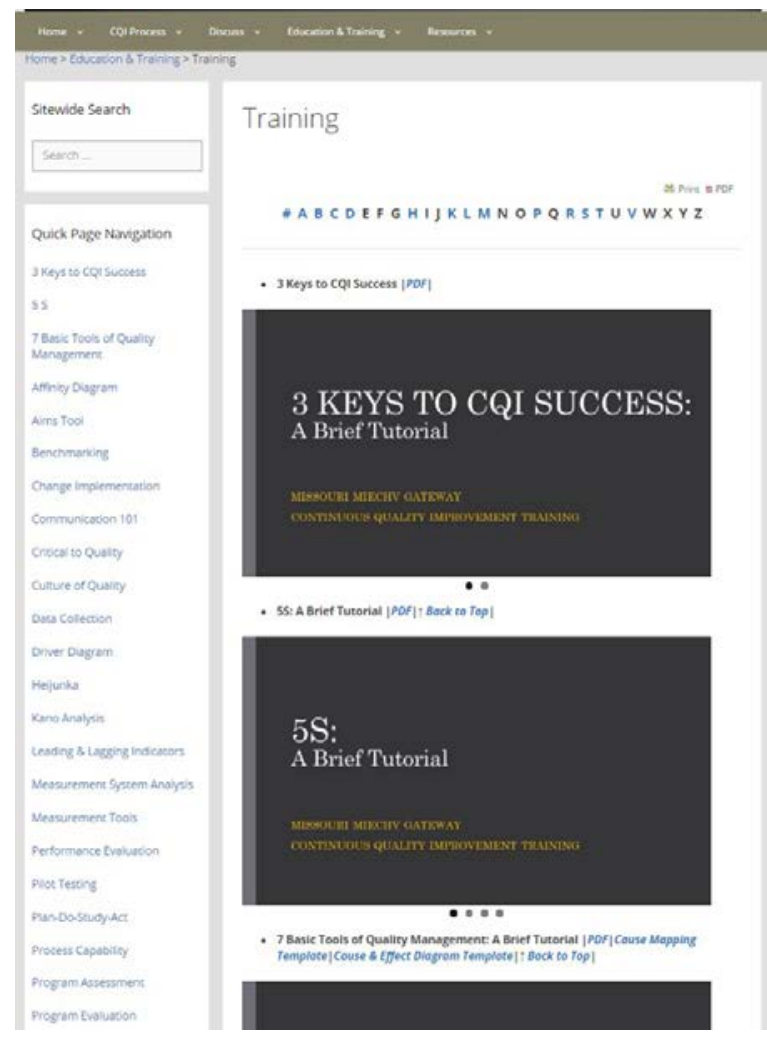

The Resources primary menu includes the secondary menu External Resources and Organization Directory pages. External Resources consists of a listing of CQI literature and articles, CQI resources from external sites, and resources surrounding specific MIECHV home visiting program constructs. To support the exchange of resources among LIAs, the Organization Directory page hosts a searchable directory of client resources. Users may add agency listings to the directory, edit existing listings, and/or search for listings by one 
or more of the following criteria: agency name, county, state, service type, and population served.

The ability to receive and respond to technical inquiries is vital to the success of the site. Along with a technical support web-based form, live chat has been integrated to encourage feedback and inquiry from users. Users may select the live chat-expanding box (located on all site pages) to connect with a Gateway Administrator. Messages received during off-peak hours receive an auto-reply, followed up with a response the next business day.

The site has been developed using a theme optimized for use with mobile devices, tablets, and desktops. Site pages can be saved in PDF format and are printer friendly. The site menu header and footer are both static across all pages while the sidebars vary by page to optimize content navigation. Finally, site functionality is continually reviewed, modified, and upgraded as needed to maintain a stable platform.

\section{User Engagement \& Social Media}

Employee engagement is defined as the extent to which employees are committed to a cause or to a person in their organization, how hard they work, and how long they stay as a result 
of that commitment [7]. Employees hold the key to organizational success in today's competitive marketplace. However, this competitive edge will not be gained until employees are properly engaged.

Engagement begins from the time of recruitment and continues throughout the time that the employee commits to the organization. The issue today is not just employing and retaining talented people, but in maintaining their attention at each stage of their work lives by engaging them [7]. We are now turning our sights to technology, social media specifically, for the purpose of engaging employees, and specifically LIA personnel with the web-based portal.

Social media sites like Twitter, Facebook, LinkedI n and web 2.0 applications like RSS newsfeeds and blogs have all been utilized with various degrees of success in an effort to increase engagement among employees. Even though social media undoubtedly has the potential to elicit employee engagement, the organizational culture and leadership buy-in are major factors that determine if social media would be implemented for the purposes of employee engagement [8]. Social media has the potential for being distracting as well as addictive. Organizations may be able to control employees' excessive use of social media by the use of management tactics [9]. Thus, it is key to 
reaching an optimal balance between utilizing social media as a tool for employee engagement and letting it distract employees to the end that organizational productivity diminishes.

A sparse amount of published literature is available on the subject of engaging employees using social media. Where literature abounds, they have emanated from case studies. These case studies focus on how certain organizations utilized social media for employee engagement. However, this is not readily generalizable as culture and leadership differ from organization to organization. In adopting the capabilities of social media for employee engagement, a number of assumptions are usually made. One major assumption is that employees are all social media savvy; the lack of capability could hinder its use. Conversely, excessive use of social media has the potential to take away from organizational productivity. When balanced, social media, if well aligned with organizational culture, has the potential to add to employee engagement.

The MIECHV Gateway site established social media accounts on Facebook, Linkedl n, and Twitter and added quick access buttons on the Gateway. To limit the audience strictly to Gateway users, the Facebook and Linkedl $\mathrm{n}$ pages required requesting membership to the 
group while the Twitter page was available for viewing/following by the general public. Feed management was optimized through the use of the network management site, Hootsuite. CQI-focused articles and latest news were fed to all three sites and Gateway webinar and sitespecific announcements were fed to the Facebook and Linkedln pages.

\section{Monitoring}

Plugin software capabilities have been adopted and integrated to monitor site activity (site visits, discussion posts, points, badges, document downloads/uploads, etc.) and capture analytics on site use. A data analytics reporting dashboard has been created to document these analytics, on a monthly and quarterly basis, and provide insight on social marketing and engagement activity needs.

To communicate and standardize software specifications across site administrators, a back-end user manual was created. This manual receives regular review and updates to document all technical specifications, theme consistencies, plugin integration, and a comprehensive listing of activities and timelines to perform site maintenance and updates. 


\section{Pilot Testing}

To optimally understand the human-computer interaction with the site, user testing is widely recognized as the most reliable method [10]. Prior to site deployment to the LIAs, pilot user testing is necessary to assess the usability of the website and provide an opportunity to make identified changes prior to full-scale deployment. To garner both expert and stakeholder feedback, pilot testing occurred in three stages, to three defined groups. The three pilot testing groups consisted of: 1) faculty and staff from the university department; 2) administrators within the state department of health; and 3) supervisors and data managers within the local implementing agencies.

\section{Results}

\section{Pilot Testing Results}

Pilot testing of group 1 occurred December 2015-January 2016, group 2 occurred February-March 2016, and group 3 April 2016. To conduct the pilot testing, group reviewers were provided access to the website, the online survey, and instructions of the review purpose and process. The survey for group 1 consisted of 13 questions, the survey from groups 2 and 3 consisted of 19 questions. Three case-based 
scenarios were developed, describing educational and professional work experiences of potential users. The survey instructs reviewers to read each case-based scenario and identify site content pages most useful to the potential user. Based on responses, the survey prompts users for narrative responses of their site experience and content suggestions. Additional survey questions evaluate how frequently reviewers would visit specific site pages, the amount of content on each page, and potential site impact on coordination, collaboration, and learning of CQI education and initiatives (Table 1 ).

Table 1, Pilot Usability Testing Results

\begin{tabular}{|l|c|c|c|}
\hline \multicolumn{1}{|c|}{ Survey Question } & N & $\begin{array}{c}\text { Point Value } \\
\text { (Minimum } \\
\text { attainable points: } \\
\text { 0; Maximum: 60) }\end{array}$ & $\begin{array}{c}\text { Mean Score } \\
\text { (Scale 0-4; } \\
\text { Strongly } \\
\text { Disagree...4 } \\
\text { Strongly Agree) }\end{array}$ \\
\hline $\begin{array}{l}\text { This site improves } \\
\text { coordination of quality } \\
\text { improvement education and }\end{array}$ & 15 & 46 & 3.06 \\
\hline $\begin{array}{l}\text { This site encourages } \\
\text { collaboration of quality } \\
\text { improvement education and } \\
\text { initiatives. }\end{array}$ & 15 & 49 & 3.27 \\
\hline $\begin{array}{l}\text { This site fosters the learning } \\
\text { of quality improvement } \\
\text { education and initiatives. }\end{array}$ & 15 & 48 & 3.20 \\
\hline
\end{tabular}

Last, reviewers within pilot testing groups 2 and 3 were asked to evaluate their overall site experience and respond to 10 statements to 
measure site effectiveness, efficiency, and satisfaction as defined within a modified version of the System Usability Scale (SUS) [11] (Table 2). The University of Missouri Institutional Review Board has reviewed these three pilot testing studies.

Table 2, Modified System Usability Scale Survey

\begin{tabular}{|c|c|}
\hline $\begin{array}{l}\text { Question } \\
\text { Number }\end{array}$ & Question \\
\hline 1 & I would use this CQI project process frequently. \\
\hline 2 & I found this CQI project process unnecessarily complex. \\
\hline 3 & I thought this CQI project process was easy to use. \\
\hline 4 & $\begin{array}{l}\text { I think that I would need the support of a technical person to } \\
\text { be able to use this CQI project process. }\end{array}$ \\
\hline 5 & $\begin{array}{l}\text { I found the various functions (features) in this CQI project } \\
\text { process were well integrated. }\end{array}$ \\
\hline 6 & $\begin{array}{l}\text { I thought there was too much inconsistency (ex. information, } \\
\text { navigation) in this CQI project process. }\end{array}$ \\
\hline 7 & $\begin{array}{l}\text { I would imagine that most people would learn to use this CQI } \\
\text { project process very quickly. }\end{array}$ \\
\hline 8 & I found this CQI project process very cumbersome to use. \\
\hline 9 & I felt very comfortable using this CQI project process. \\
\hline 10 & $\begin{array}{l}\text { I needed to learn a lot of things before I could begin using this } \\
\text { CQI project process. }\end{array}$ \\
\hline
\end{tabular}


Results of the three pilot testing groups were overall positive, desirable, and vital to improving the site for full-launch implementation. The majority (87\%) of reviewers reported they would access/use the learning materials (e.g. CQI project process, training tutorials, resources, etc.), stated they would use the site for completing quality improvement projects $(80 \%)$, and reported the site would help their work teams address internal quality improvement challenges $(66 \%)$.

Reviewers were asked to submit feedback for expansion, modification, or further development of the site content through survey prompts allowing for narrative responses. Reviewers submitted a total of 98 narrative responses, with 19 from pilot group 1 (average 2.7 per user), 50 from pilot group 2 (average of 6.3 per user), and 29 from pilot group 3 (average of 4.1 per user).

Reviewers reported they would "frequently/regularly" (64\%) or "occasionally" visit (30\%) the primary pages (including Home Page, CQI Storyboard Library, Discussion Forum, Current CQI Project Tracker, and CQI Process pages). Reviewers reported they would "frequently/regularly" (32\%) or "occasionally" (54\%) visit learning and resource pages (including External Resources, MIECHV, Glossary, 
Organization Directory, Training, Events, and Groups). In evaluating the amount of content on 20 individual site pages, $75 \%$ reported the site pages included the right amount of content, 15\% reported the certain site pages were in need of improvement, and $10 \%$ reported too much content on certain site pages. The majority of reviewers reported feeling "comfortable" or "highly comfortable" in sharing experiences, practices, and/or concerns in the following site areas: open discussion forums ( $88 \%$ ); closed groups (100\%); private messaging (88\%); and feedback submission forms (100\%).

The majority of pilot reviewers approved of the "Program Fidelity \& CQI Assessment" site assessment tool. Most reported the assessment tool was easy to use ( $79 \%)$, and the purpose of the assessment was clear (86\%). Reviewers were able to use the assessment to self-identify areas where quality improvement work would be beneficial ( $75 \%$ ). The majority of reviewers stated the assessment recommendations were appropriate (79\%). Reviewers identifying the next step in the CQI process after completing the assessment was the lowest rated survey item (72\%). The overall satisfaction and usability of the assessment by reviewers calculated as 3.10 out of a maximum of $4(78 \%)$ (Table 3 ). 
Table 3, Program Fidelity \& CQI Assessment Evaluation Survey Results

\begin{tabular}{|l|c|c|c|c|c|c|c|}
\hline Survey Question & $\begin{array}{c}\text { Group } \\
\mathbf{2} \text { N }\end{array}$ & $\begin{array}{c}\text { Group } \\
\mathbf{2} \\
\text { Mean } \\
\text { Score }\end{array}$ & $\begin{array}{c}\text { Group } \\
\mathbf{3} \text { N* }\end{array}$ & $\begin{array}{c}\text { Group } \\
\mathbf{3} \\
\text { Mean } \\
\text { Score }\end{array}$ & $\begin{array}{c}\text { Point } \\
\text { Total } \\
\text { Nalue }\end{array}$ & $\begin{array}{c}\text { Mean } \\
\text { Score } \\
\text { (Minimum } \\
\text { attainable } \\
\text { points: 0; } \\
\text { Maximum: } \\
\text { (Scale 0-4; } \\
\text { o Strongly } \\
\text { Disagree.. } \\
\text { 4 Strongly } \\
\text { Agree) }\end{array}$ \\
\hline $\begin{array}{l}\text { The assessment is } \\
\text { easy to use. }\end{array}$ & 8 & 3.13 & 6 & 3.17 & 14 & 44 & 3.14 \\
\hline $\begin{array}{l}\text { The purpose of the } \\
\text { assessment is } \\
\text { clearly stated. }\end{array}$ & 8 & 3.50 & 6 & 3.33 & 14 & 48 & 3.43 \\
\hline $\begin{array}{l}\text { The assessment } \\
\text { allows users to } \\
\text { self-identify areas } \\
\text { where quality } \\
\text { improvement work } \\
\text { may be beneficial. }\end{array}$ & 8 & 2.88 & 6 & 3.17 & 14 & 42 & 3.00 \\
\hline $\begin{array}{l}\text { The assessment } \\
\text { recommendations } \\
\text { appear on target. }\end{array}$ & 8 & 4.13 & 6 & 3.17 & 14 & 44 & 3.14 \\
\hline $\begin{array}{l}\text { At the conclusion } \\
\text { of the assessment, } \\
\text { it was clear what } \\
\text { my next step in the } \\
\text { CQl process was. }\end{array}$ & 8 & 2.75 & 6 & 3.00 & 14 & 40 & 2.86 \\
\hline $\begin{array}{l}\text { The assessment is } \\
\text { useful in measuring } \\
\text { fidelity to a } \\
\text { program model. }\end{array}$ & 8 & 3.00 & 6 & 3.00 & 14 & 42 & 3.00 \\
\hline
\end{tabular}




\begin{tabular}{|l|c|c|c|c|c|c|c|}
\hline Survey Question & $\begin{array}{c}\text { Group } \\
\text { 2 N }\end{array}$ & $\begin{array}{c}\text { Group } \\
\mathbf{2} \\
\text { Mean } \\
\text { Score }\end{array}$ & $\begin{array}{c}\text { Group } \\
\mathbf{3} \text { N* }\end{array}$ & $\begin{array}{c}\text { Group } \\
\mathbf{3} \\
\text { Mean } \\
\text { Score }\end{array}$ & $\begin{array}{c}\text { Point } \\
\text { Value } \\
\text { Total } \\
\text { N Minimum } \\
\text { attainable } \\
\text { points: 0; } \\
\text { Maximum: } \\
\text { 60) }\end{array}$ & $\begin{array}{c}\text { Mean } \\
\text { Score } \\
\text { (Scale 0-4; } \\
\text { O Strongly } \\
\text { Disagree... } \\
\text { 4 Strongly } \\
\text { Agree) }\end{array}$ \\
\hline $\begin{array}{l}\text { Overall usability of } \\
\text { the Program } \\
\text { Fidelity \& CQI } \\
\text { Assessment } \\
\text { (Measured by } \\
\text { individual evaluation } \\
\text { of the following six } \\
\text { questions: ease of } \\
\text { use, clearly stated, } \\
\text { recommendations } \\
\text { appear on target, } \\
\text { allows users to self- } \\
\text { identify areas where } \\
\text { quality improvement } \\
\text { work may be } \\
\text { beneficial, clarity of } \\
\text { next step, and useful } \\
\text { in measuring fidelity } \\
\text { to a program model) }\end{array}$ & 8 & 3.06 & 6 & 3.14 & 14 & & \\
\hline
\end{tabular}

* Group 3 had seven reviewers complete the survey, one reviewer did not respond to the series of questions presented in Table 3.

Site improvements made between pilots 2 and 3 were found to benefit the overall site usability and increased the site's SUS score by $10 \%$ (6.9 points). The modified SUS score of pilot testing group 2 was 68.4, group 3 was 75.4, and weighted mean score of the two pilot groups calculated as 71.6, ranking above the U.S. average of 68 [12]. 


\section{Site Launch \& Results}

The site launched to 58 users (47 LIAs; 11 MoDHSS). Prior to launch, LIAs and MoDHSS managers provided user registration data to establish unique user accounts with appropriate roles for Gateway users. New users received an automated email with the site web address, unique username, temporary password, instructions to change their password, and general information on utilizing the site. A 10- part live-stream weekly webinar series was offered to users. Webinars were recorded and posted, with the accompanying slide deck, on the Gateway Webinars page. A total of 44 participants, across five agencies, joined the live webinars.

Site performance and activity were measured through integrated software capabilities. Site stability and performance were exceptional. Throughout the 12-weeks the site was open to users, the site experienced six minutes of total site downtime. Downtime was planned to update plugins. The integrated software capabilities that monitor site activity (e.g. visits, visitors, posts, downloads, activity points, technical support inquiries, etc.) capture analytics on site use. Site activity metrics were gathered and reported in monthly "MIECHV 
Gateway Site Metrics Dashboard" to MoDHSS administrators (Figure 4).

Figure 4, MIECHV Gateway Site Metrics Dashboard, September 2016

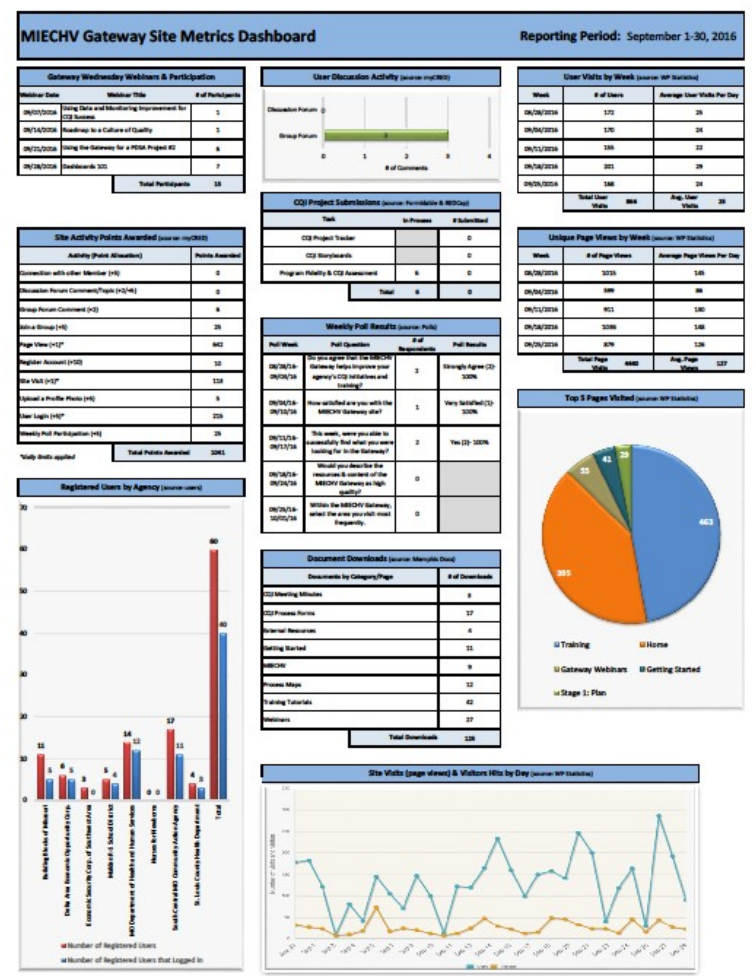

At the conclusion of the contract period (09/30/2016), a total of 60 users (46 LIAs; 14 MoDHSS) were registered with 40 active users (66.7\% adoption rate). The site averaged 29 page views per day, awarded 3,178 site activity points, and had 540 document downloads. The Training page was most frequently visited by users. In regards to social media engagement, at the end of the contract period, there 
were no members or followers (other than Gateway administrators) to any of the three social media sites. Further surveying of LIA users is necessary to determine if users utilize social network sites, access social media sites in the workplace, access internet and internetaccessible devices at both work and home, and share opinions on using social media for business/employment purposes.

\section{Limitations}

The development, build, and launch of this quality improvement practice exchange virtual environment achieved its overarching aim in developing a widely accepted web-based environment to balance CQI training and practice and increase the capacity for organizational change. Still, unavoidable limitations exist. First, significant run-time is essential for adoption and utility of any new technology. The short run (12 weeks) did not allow adequate time for a pilot test where generalizable impact to larger user populations could be assured. Further and lengthier pilots are necessary to gather and analyze key trends over time such as fidelity score measurements, average site utilization by user, PDSA submission rates, participation by agency, benchmark and construct performance improvements, and others. Second, a lack of prior studies on comparable web-based tools pose 
challenges in the ability to set baseline measurements of whether the web-based CQI intervention achieved meaningful success. Lastly, from conceptualizing a problem for improvement to measurement of current to future-state change to monitoring and maintaining the change, there is a strong reliance on certifiable and accessible program performance data. Due to data reporting system barriers, external and independent from the site, shared performance data was unable to be integrated as a site resource. However, program reports remained accessible to users via their designated LIA supervisor, yet the convenience benefits of directly accessing data reports from within the site could not be achieved during the time of the study.

\section{Discussion \& Conclusion}

Advances in web-based collaborative workplace environments offer tremendous potential to improve dissemination of information, access to standardized educational materials, distance collaborations, and overall quality of program delivery and performance. To our knowledge, a virtual environment aimed to create a culture of quality improvement and foster CQII for home visiting program LI As has not been previously reported. The Missouri MIECHV Gateway site hosts key characteristics advocated by experts in CQI, website development, and 
online learning environments. Development of the Gateway environment aimed to complement the existing MIECHV CQI framework. We were successful in meeting these aims by: 1) adding CQI elements that are missing or ineffective, such as standardized training tutorials, webinars, and structured CQI project forms, 2) adding elements for CQI identification and program evaluation, such as the "Program Fidelity and CQI Assessment" and 3) offering LIAs a network to share CQI experiences and collaborate at a distance, through avenues such as the discussion forums and the CQI Storyboard Library. We built a stable site that successfully: achieved an above average (71.6) usability score, developed an acceptable (78\% overall satisfaction) fidelity self-assessment tool to prioritize CQI activities, and concluded with a site adoption rate of $67 \%$ averaging 29 page views per day.

Throughout the process of developing and launching the Missouri MIECHV Gateway, many lessons are learned. First, the site design is fluid, and it appears to address required flexibility, creativity, and adaptability [13]. The integration of features within the site is not limited, with the widespread availability of third-party plugins one does not typically require a robust programming background to implement 
new features. Second, encouraging open communication, stakeholder buy-in, and ongoing feedback was a necessary activity in garnering shared vision and ownership of the site [14]. Stakeholder feedback remains a vital part of the site design and development. Frequent meetings continued to occur with administrators of the state health department, and with LIAs throughout the contract period.

Additionally, further pilots are necessary to understand how individuals are motivated to use the site. Finally, the systematic approach to CQI of examining performance relative to targets requires the integration of real-time data, dashboards, and reports powered by information technology and informatics frameworks $[15,16]$.

The site adds value to quality improvement beyond this presented scope of work. This value virtually connects users and embeds them within an environment balancing CQI training and practice [17]. Expansion of this site has endless opportunities given the focus on CQI priorities. From the addition of expanded training tutorials to the expanded integration of digital tools to the measurement of fidelity and outcomes from CQII, these features and characteristics aim to improve and enhance the site. More longitudinal assessments will be needed to further measure and evaluate the 
Gateway site impact on programs and agencies beyond the built population.

\section{Acknowledgments}

We are grateful to the Missouri Department of Health and Senior Services' MIECHV program leadership and project personnel for their diligent efforts in implementing this innovative program.

Funding: This project is supported by the Health Resources and Services Administration (HRSA) of the U.S. Department of Health and Human Services (HHS) under grant number D89MC2791501-

Affordable Care Act (ACA) Maternal, Infant, and Early Childhood Home Visiting Program in the Amount of $\$ 886,521$ with $0 \%$ financed with nongovernmental sources. This information or content and conclusions are those of the authors and should not be construed as the official position or policy of, nor should any endorsements be inferred by HRSA, HHS or the U.S. Government.

\section{Funding Acknowledgement}

This project is supported by the Health Resources and Services Administration (HRSA) of the U.S. Department of Health and Human Services (HHS) under grant number D89MC2791501-Affordable Care Act (ACA) Maternal, Infant, and Early Childhood Home Visiting 
Program in the Amount of $\$ 886,521$ with $0 \%$ financed with nongovernmental sources. This information or content and conclusions are those of the authors and should not be construed as the official position or policy of, nor should any endorsements be inferred by HRSA, HHS or the U.S. Government. 


\section{References}

1. Sweet M, Appelbaum M. 2004. Is home visiting an effective strategy? A meta-analytic review of home visiting programs for families with young children. Child Dev. 75(5), 1435-56.

2. U.S. Department of Health and Human Services Health Resources and Services Administration. Quality Improvement. n.d. Available from: http://www.hrsa.gov/quality/toolbox/ methodology/qualityimprovement/.

3. Davis P, Solomon J, Gorenflo G. 2010. Driving quality improvement in local public health practice. J Public Health Manag Pract. 16(1), 67-71.

4. Ammerman R, Putnam F, Kopke J, Gannon T, Short J, et al. 2007. Development and implementation of a quality assurance infrastructure in a multisite home visitation program in ohio and kentucky. J Prev Intervent Community. 34(1-2), 89-107.

5. Krug S. Don't Make Me Think, Revisited: A Common Sense Approach to Web Usability: New Riders; 2014.

6. Deming W. Out of the Crisis. Cambridge, MA: Massachusetts Institute of Technology Centre for Advanced Engineering Study xiii; 1983. 
7. Lockwood NR. 2007. Leveraging employee engagement for competitive advantage. Society for Human Resource Management Research Quarterly. 1, 1-12.

8. Parry E, Solidoro A. 2013. Social media as a mechanism for engagement. Advanced Series in Management. 12, 121-41.

9. Herlle M, Astray-Caneda V. The Impact of Social Media in the Workplace. 2013:67-73.

10. Woolrych A, Cockton G, eds. Why and when five test users aren't enough. IHM-HCl 2001 conference; 2001; Toulouse, FR.

11. Brooke J. SUS: a "quick and dirty" usability scale. Usability Evaluation in Industry. 1996.

12. Sauro J, Kindlund E, eds. A method to standardize usability metrics into a single score. Proceedings of the SIGCHI conference on Human factors in computing systems; 2005: ACM.

13. Radaideh MDA. Architecture of Reliable Web Applications Software: IGI Global; 2006.

14. Alexander M. Lead or Lag: Linking Strategic Project Management \& Thought Leadership: Lead-Her-Ship Group; 2016. 
15. Ghazisaeidi M, Safdari R, Torabi M, Mirzaee M. 2015.

Development of performance dashboards in healthcare sector: key practical issues. Acta Inform Med. 23(5), 317.

16. Institute of Medicine. Crossing the quality chasm: a new health system for the 21 st century. Washington, D.C.: National Academy Press; 2001.

17. Anderson $\mathrm{T}$. The theory and practice of online learning: Athabasca University Press; 2008. 


\title{
CHAPTER 3 - PSYCHOMETRI C PROPERTIES OF PATI ENT-FACI NG EHEALTH EVALUATI ON MEASURES: SYSTEMATIC REVIEW AND
}

\author{
ANALYSIS \\ Bonnie J Wakefield ${ }^{1}$, PhD; Carolyn L Turvey ${ }^{1}, \mathrm{PhD}$; Kim M Nazi², PhD; \\ John E Holman¹, MA, MS; Timothy P Hogan³, PhD; Stephanie L \\ Shimada ${ }^{3}, \mathrm{PhD}$; Diana R Kennedy ${ }^{4}, \mathrm{MHA}, \mathrm{MS}$ \\ ${ }^{1}$ The Center for Comprehensive Access and Delivery Research and Evaluation, Iowa \\ City Veterans Affairs Healthcare System, I owa City, IA, United States \\ ${ }^{2}$ Veterans and Consumers Health Informatics Office, Veterans Health Administration, \\ Washington, DC, United States \\ ${ }^{3}$ Center for Healthcare Organization and Implementation Research, Edith Nourse \\ Rogers Memorial Veterans Affairs Medical Center, Boston, MA, United States \\ ${ }^{4}$ Department of Health Management and Informatics, University of Missouri, \\ Columbia, MO, United States
}

\section{Abstract}

BACKGROUND: Significant resources are being invested into eHealth technology to improve health care. Few resources have focused on evaluating the impact of use on patient outcomes A standardized set of metrics used across health systems and research 
will enable aggregation of data to inform improved implementation, clinical practice, and ultimately health outcomes associated with use of patient-facing eHealth technologies. OBJ ECTIVES: The objective of this project was to conduct a systematic review to (1) identify existing instruments for eHealth research and implementation evaluation from the patient's point of view, (2) characterize measurement components, and (3) assess psychometrics. METHODS: Concepts from existing models and published studies of technology use and adoption were identified and used to inform a search strategy. Search terms were broadly categorized as platforms (eg, email), measurement (eg, survey), function/information use (eg, self-management), health care occupations (eg, nurse), and eHealth/telemedicine (eg, mHealth). A computerized database search was conducted through June 2014. Included articles (1) described development of an instrument, or (2) used an instrument that could be traced back to its original publication, or (3) modified an instrument, and (4) with full text in English language, and (5) focused on the patient perspective on technology, including patient preferences and satisfaction, engagement with technology, usability, competency and fluency with technology, computer literacy, and trust in and acceptance of technology. The 
review was limited to instruments that reported at least one psychometric property. Excluded were investigator-developed measures, disease-specific assessments delivered via technology or telephone (eg, a cancer-coping measure delivered via computer survey), and measures focused primarily on clinician use (eg, the electronic health record). RESULTS: The search strategy yielded 47,320 articles. Following elimination of duplicates and non-English language publications $(n=14,550)$ and books $(n=27)$, another 31,647 articles were excluded through review of titles. Following a review of the abstracts of the remaining 1096 articles, 68 were retained for full-text review. Of these, 16 described an instrument and six used an instrument; one instrument was drawn from the GEM database, resulting in 23 articles for inclusion. None included a complete psychometric evaluation. The most frequently assessed property was internal consistency $(21 / 23,91 \%)$. Testing for aspects of validity ranged from $48 \%(11 / 23)$ to $78 \%(18 / 23)$. Approximately half $(13 / 23$, $57 \%$ ) reported how to score the instrument. Only six (26\%) assessed the readability of the instrument for end users, although all the measures rely on self-report. DISCUSSION: Although most measures identified in this review were published after the year 2000, rapidly 
changing technology makes instrument development challenging. Platform-agnostic measures need to be developed that focus on concepts important for use of any type of eHealth innovation. At present, there are important gaps in the availability of psychometrically sound measures to evaluate eHealth technologies. (J Med Internet Res 2017; 19(10):e346) doi: 10.2196/jmir.7638 KEYWORDS: telemedicine; computers; evaluation; use-effectiveness; technology; psychometrics

\section{I ntroduction}

Patient-facing eHealth is a multidisciplinary field focused on the delivery or enhancement of health information and health services through information and communication technologies [1]. eHealth helps consumers engage and collaborate more fully in their health care $[2,3]$, independent of geographic location and also enhances access to health care services by offering novel channels for communication and information flow that complement existing systems [4]. There are many terms related to eHealth, including consumer health informatics, digital health, virtual care, connected care, and telehealth, to list only a few. For purposes of consistency, we use the term "eHealth." 
This paper focuses on patient use of eHealth, which includes personal health records and patient portals accessed via computers or mobile devices, and other telehealth devices designed for use primarily by patients and caregivers, even though some patient-facing technologies (eg, secure patient-provider messaging, mobile apps) are also used by clinicians [5]. Several constructs are important to measure to evaluate patient-facing eHealth technologies. Patientfacing eHealth technologies are used to deliver interventions intended to promote healthy behaviors or effective self-management among consumers. When assessing the efficacy of a behavior-change eHealth intervention, evaluations must address both the intervention and the technology platforms and functions used to deliver the intervention in terms of usability, functionality, and availability of the technology to target users [3]. eHealth may improve the efficiency of and accessibility to clinical and health promotion services for patients. For example, it is anticipated that eHealth may reduce the distance between services and the target user, improving accessibility, or reducing physician or patient workload for a specific task, enhancing efficiency [6-9]. Finally, almost all behavior-change eHealth 
interventions aim to improve communication in one form or another $[10,11]$

Although studies using eHealth technologies may include measures that attempt to quantify the characteristics or effect of eHealth interventions, to date, there are no uniform, widely agreed-on measures. More rigorous measurement is needed to determine the full benefit(s) of an eHealth-delivered intervention to both patients and the health care system [12]. Scientific inquiry in other domains has benefited from the development of such standardized measures. At present, various measure compendiums are available that categorize measures of patient-reported outcomes. The Grid-Enabled Measures (GEM) database, for example, was developed starting in 2010 with the purpose of moving social and behavioral science forward by promoting the use of standardized measures tied to theoretically based constructs and facilitating sharing of data from use of standardized measures [13]. Sponsored by the National Cancer Institute, GEM is an open-source measure compendium that solicits scientific community participation in contributing and selecting measures. Users can add information about constructs, find measures related to constructs, upload new measures, provide feedback on existing measures, and 
search for and share harmonized data for meta-analyses. In addition to providing useful information such as associated references and information on validity and reliability, the GEM allows researchers to see how often other researchers have used a measure and the feedback and ratings they have provided.

Similarly, the Patient-Reported Outcomes Measurement System (PROMIS) was developed by the National Institutes of Health in an effort to develop, validate, and standardize items that may be used to measure patient-reported outcomes common across medical conditions [14]. PROMIS is collecting and testing items focused on patient-reported outcomes of interest, as opposed to validated instruments. For example, the item banks for physical function, fatigue, and sleep disturbance contain 124, 95, and 27 items, respectively [15]. These item banks are being tested in large populations [16-18].

Both PROMIS and GEM promote use of standardized measures and data analysis across multiple studies and conditions. Although these measures can be an important component of studies focused on use of eHealth technologies, the items and instruments contained in these compendiums do not specifically focus on issues surrounding use 
of eHealth technology with and by patients. For example, although GEM or PROMIS may include instruments or items that measure patient satisfaction with communication with a physician, they do not include items specific to physician-patient communication when using telehealth or secure messaging, nor do they specifically address technology usability issues. Recent efforts to summarize measures related specifically to technology use include a compendium of health information technology-related survey tools developed by the Agency for Healthcare Research and Quality (AHRQ). The AHRQ compendium includes a wide variety of measures, but the website does not provide detailed information on psychometric properties. Thus, although work is in progress to develop and identify measures that may address eHealth evaluation needs, more work is needed.

Implementation research focuses on structural and organizational characteristics of the environment where an innovation is being or will be used. Within this environment are individuals (patients, providers, administrators) with various characteristics that may hinder or facilitate adoption of the innovation within the particular environment. In this review, we focus on the innovation (ie, the eHealth intervention) and how features of this innovation will impact 
implementation. Consistent and well-validated measures will contribute to determining the true benefit of eHealth interventions across studies and over time. Consistently used measures will enable the health care system to collect uniform data on (1) the likelihood of adoption of an eHealth technology; (2) patient, organizational, or health care system barriers and facilitators to adoption; (3) user attitudes toward and/or satisfaction with a technology; (4) the degree to which meaningful user characteristics (eg, health literacy) mediate the relationship between technology use and improved health outcomes (ie, improved self-management of chronic illness, reduced health care utilization), and (5) the return on investment of eHealth technology to assess value.

The objective of this project was to conduct a systematic review to (1) identify existing instruments for eHealth research and implementation evaluation, (2) characterize measurement components, and (3) assess psychometrics. Additionally, this study seeks to highlight current limitations of this body of research. 


\section{Methods}

\section{I dentification of Search Terms}

Through a series of investigator meetings, we identified key concepts from existing models, published studies of technology use and adoption, and sociotechnical perspectives on health information technology implementation and evaluation [19-23]. Using these models and studies, our knowledge of the field, and detailed input from an experienced health sciences librarian, we developed a working list of key concepts to focus our search. These were then categorized into five areas: platforms (eg, email), measurement (eg, survey), function/information use (eg, self-management), health care occupations (eg, nurse), and eHealth/telemedicine (eg, mHealth) (Multimedia Appendix 1). Our focus was to identify instruments that could be used for any of these concepts as well as those that may be relevant to only one or two concepts.

\section{Search Strategy}

We conducted a systematic search of the literature using the selected search terms. Based on guidance from our health sciences librarian, databases used included MEDLINE, Scopus, Psychlnfo, 
CINAHL, Health and Psychosocial Instruments (HAPI) for articles published through J une 2014. Each database was searched using terms included in Multimedia Appendix 1. The search logic followed this format: ( $A$ and $D$ and $B$ and $C$ ) OR ( $E$ and $B$ and $C$ ). All terms listed in sets $A, B, D$, and $C$ were entered and combined using the Boolean operator "and." Likewise, terms in sets B, C, and E were entered and combined using "and." The results from these two searches were then combined using the operator "OR." This logic was used to ensure all possible terms were included and ensured studies included some sort of measurement or evaluations.

Our search strategy also included review of currently funded research projects within the health services research arm of the Veterans Health Administration (VA) system focused on eHealth $(n=56)$, and existing instrument/measure compendiums (GEM, PROMIS, AHRQ). All search results were transferred to a reference management software database (EndNote); duplicates, articles where the text was not in English, and books were eliminated.

\section{Inclusion Criteria}

Our article inclusion criteria were broad to identify the full extent of instruments designed for eHealth research and implementation 
evaluation. We focused explicitly on instruments that assessed an eHealth-specific construct from the patient's point of view. Articles were selected if they (1) described development of an instrument, or (2) used an instrument in an evaluation of an eHealth technology that could be traced back to an original publication describing its development, or (3) modified an instrument, and (4) with full text in English language. The review was limited to instruments that reported at least one psychometric property. Excluded were investigatordeveloped measures or sets of questions without psychometric evaluation, disease-specific assessments delivered via technology or telephone (eg, a cancer-coping measure delivered via computer survey), and measures focused primarily on clinician use (eg, the electronic health record). We limited our review to articles that reported at least one established psychometric property (see Table 1 for psychometric evaluation components).

\section{Data Extraction}

Two investigators and a research assistant (BW, JH, AM) independently reviewed 100 article titles followed by an in-depth discussion to establish agreement on inclusion of articles. Next, the review was repeated two times using an additional 100 article titles 
each time, until agreement was reached on articles to include for further review. All article titles were then reviewed to exclude ineligible articles. The abstracts of the remaining articles were reviewed by a pair of investigators (BW, CT) following an independent review of 20 articles to establish interrater consistency. The remaining abstracts were then independently reviewed and discrepancies between reviewers were resolved by discussion and consensus. Articles that did not meet criteria were excluded (no instrument, use of an instrument, or instrument modification), and remaining articles were retained for full-text review. Articles were then classified as describing the development and testing of an instrument or as using an instrument. For articles using an instrument, reference lists were reviewed to identify citations for the original instrument development.

A data extraction form with definitions for each item was developed by the study team (Table 1) [24]. To establish interrater reliability in data extraction, coauthors were divided into pairs, and were assigned to independently review two articles using the data extraction tool. These reviews were discussed in depth by the whole study team to reach consensus on the definitions used in Table 1. Following minor revisions of the data extraction form, articles from the 
search were then distributed among the six study investigators for final review and data extraction. The first author then reviewed each article and data extraction information to ensure accuracy.

Table 1, Data extraction elements

\begin{tabular}{|c|c|}
\hline Element & Definition \\
\hline Construct & $\begin{array}{l}\text { Constructs are not directly observable, but may } \\
\text { be applied and defined based on observable } \\
\text { behavior; many health measures are designed } \\
\text { to capture some aspect of an underlying } \\
\text { construct. } \\
\text { In the authors' own words, what the authors of } \\
\text { the scale say they are measuring. }\end{array}$ \\
\hline Theoretical foundation & $\begin{array}{l}\text { Conception of how attributes exist in reality and } \\
\text { relate to one another; theoretical framework; } \\
\text { can indicate that a conceptual framework } \\
\text { (concepts identified in the framework) was } \\
\text { used. }\end{array}$ \\
\hline $\begin{array}{l}\text { Modification of another } \\
\text { instrument by others } \\
\text { (alternate forms) } \\
\text { abbreviated, short forms, } \\
\text { different forms targeting the } \\
\text { same construct, translations }\end{array}$ & $\begin{array}{l}\text { State if this article is a modification of the } \\
\text { format or administration of an instrument } \\
\text { already evaluated for psychometric properties. }\end{array}$ \\
\hline$\#$ items & Number of items included in the measure. \\
\hline Item types & $\begin{array}{l}\text { Structure of the items: e.g., Likert-type, } \\
\text { categorical (multiple options), open ended, } \\
\text { yes/no, visual analogue scale, other. }\end{array}$ \\
\hline Administration time & $\begin{array}{l}\text { Estimated amount of time for completion of the } \\
\text { measure. }\end{array}$ \\
\hline Administration mode & $\begin{array}{l}\text { Assessment completed by self-report vs } \\
\text { interviewer/researcher administered. }\end{array}$ \\
\hline $\begin{array}{l}\text { Active vs. Passive } \\
\text { assessment/obtrusiveness }\end{array}$ & $\begin{array}{l}\text { Data collection which does not involve direct } \\
\text { solicitation from the research subject or other } \\
\text { participant; indirect ways to obtain the } \\
\text { necessary data often relying on technology } \\
\text { captured information such as response time, } \\
\text { number of navigation errors, etc. }\end{array}$ \\
\hline Item development & $\begin{array}{l}\text { Briefly overview how items were developed for } \\
\text { the original form of the measure (e.g., expert } \\
\text { generation of items, compilation of items from } \\
\text { prior measures). }\end{array}$ \\
\hline Scoring & Describe how the measure is scored, include a \\
\hline
\end{tabular}




\begin{tabular}{|c|c|}
\hline Element & Definition \\
\hline & $\begin{array}{l}\text { range of possible scores and other descriptive } \\
\text { statistics such as significant threshold scores if } \\
\text { available. }\end{array}$ \\
\hline Readability & $\begin{array}{l}\text { Did the developers test the readability of the } \\
\text { measure? Were any readability formulas used } \\
\text { (e.g., Flesch-Kincaid). }\end{array}$ \\
\hline Sensitivity to change & $\begin{array}{l}\text { Ability to detect change over time, particularly } \\
\text { in response to some intervention; also known } \\
\text { as responsiveness; floor and ceiling effects. }\end{array}$ \\
\hline Reliability: test-retest & $\begin{array}{l}\text { Consistency in scores between } 2 \\
\text { administrations of the measure separated by a } \\
\text { time period (e.g.,., same subject completes the } \\
\text { measure twice). }\end{array}$ \\
\hline Reliability: inter-rater & $\begin{array}{l}\text { Consistency between } 2 \text { independent observers } \\
\text { using the measure (for measures that involve } \\
\text { observing subjects) \% agreement, kappa. }\end{array}$ \\
\hline $\begin{array}{l}\text { Reliability: internal } \\
\text { consistency }\end{array}$ & $\begin{array}{l}\text { Degree to which all items in the scale correlate } \\
\text { with each other taking length of measure into } \\
\text { account, indicating the items are measuring the } \\
\text { same underlying construct. Based on a single } \\
\text { administration of the measure; Cronbach's } \\
\text { alpha, Kuder-Richardson, split-half reliability. }\end{array}$ \\
\hline Validity: content & $\begin{array}{l}\text { Typically, from a review of the literature or } \\
\text { review by experts. }\end{array}$ \\
\hline $\begin{array}{l}\text { Validity: criterion, } \\
\text { convergent, concurrent, } \\
\text { discriminant }\end{array}$ & $\begin{array}{l}\text { Correlation of the scale with other measures to } \\
\text { determine independence from other constructs } \\
\text { yet some positive correlation to similar } \\
\text { constructs and negative correlation to dissimilar } \\
\text { constructs. }\end{array}$ \\
\hline Validity: construct & $\begin{array}{l}\text { Linking the measure to another known } \\
\text { attribute. Factor analysis to identify proposed } \\
\text { underlying constructs consistent with proposed } \\
\text { theoretic content of the measure. }\end{array}$ \\
\hline Sample & $\begin{array}{l}\text { Patient population used to develop, validate, or } \\
\text { test the measure. }\end{array}$ \\
\hline $\begin{array}{l}\text { Sample studies using the } \\
\text { metric/strength of evidence }\end{array}$ & $\begin{array}{l}\text { Studies using the measure including those that } \\
\text { did not present psychometric properties of the } \\
\text { measure. }\end{array}$ \\
\hline Measure website address & $\begin{array}{l}\text { If the measure has an associated website, list } \\
\text { the website address here and note the date of } \\
\text { last update, if available. }\end{array}$ \\
\hline $\begin{array}{l}\text { Copyright or fees associated } \\
\text { with use of the measure }\end{array}$ & $\begin{array}{l}\text { Requires purchase of the measure or the } \\
\text { scoring algorithm? }\end{array}$ \\
\hline
\end{tabular}




\section{Results}

The search strategy yielded 47,320 articles (PubMed: $n=16,968$;

Scopus: $n=24,106$; Psychl nfo: $n=3590$; CINAHL: $n=2187$; HAPI:

$n=468 ;$ GEM: $n=1$ ). Following elimination of duplicates and full text not in English language publications $(n=14,550)$ and books $(n=27)$, most articles were excluded through review of titles $(n=31,647)$. Following a review of the abstracts of the remaining 1096 articles, 68 were retained for full-text review.

Of these, 16 described an instrument and six used an instrument; one instrument was drawn from the GEM database, resulting in 23 articles for inclusion in the review (Figure 1). Of these 23 articles, seven were modifications of existing instruments. No additional measures were identified through our VA, PROMIS, or AHRQ search. Each article was then reviewed by team members, using the data extraction form (Table 1).

We identified common conceptual threads across the 23 instruments. We reviewed the literature to identify salient concepts and constructs from existing technology use models [19-22, 25]. Multiple constructs were identified and terminology varied across models. For example, the Technology Acceptance Model includes 16 
constructs in four categories (behavioral intention, perceived usefulness, perceived ease of use, and use behavior). Although terminology varied by author and model, categorizations were inferred and grouped. Twelve concepts emerged from this categorization: clinical content, communication, effectiveness, efficiency, frequency/consistency of use, hardware and software, perceived ease of use, policies and procedures, risk and benefits, user preferences, social influence, and usability. Author definitions guided this categorization. The definition of several of these terms are intuitive (eg, effectiveness), but some are not and are briefly defined here. Efficiency includes the concepts of accuracy, costs, learnability, performance expectations, productivity, quality of use, and workflow. Learnability is an aspect of usability and refers to the ease of learning how to use software. Closely related to learnability is performance expectation, where the end user knows what is expected from them to use the software. Hardware and software aspects include availability, human-computer interface (ie, efficient and desirable interaction between a person and the computer), information display, system maintenance and monitoring, and technical quality. Perceived ease of use incorporates anxiety about and attitude toward using a computer, 
behavioral intention (the likelihood that an individual will use the computer), computer self-efficacy, engagement, enjoyment, and

\section{usefulness.}

Figure 1, Flow diagram of search

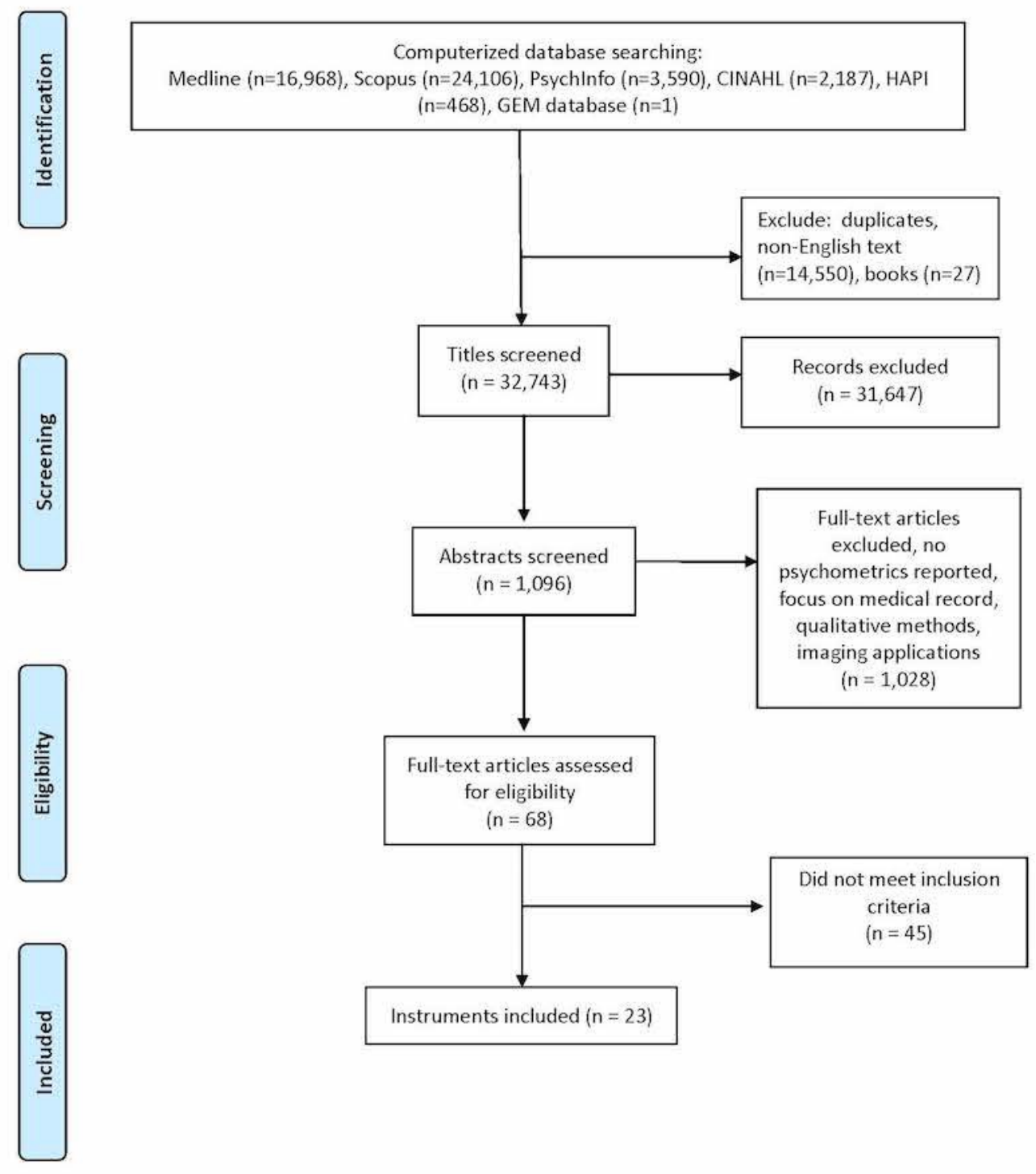


Table 2, Concepts 1 to 6 identified in reviewed instruments $(\mathrm{N}=23)$

\begin{tabular}{|c|c|c|c|c|c|c|}
\hline \multirow[t]{2}{*}{ Article } & \multicolumn{6}{|c|}{ Concept and model authors } \\
\hline & 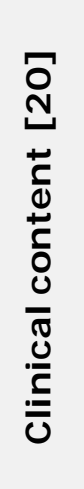 & 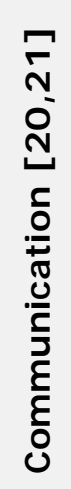 & 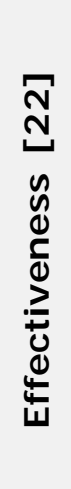 & 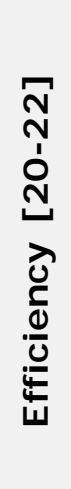 & 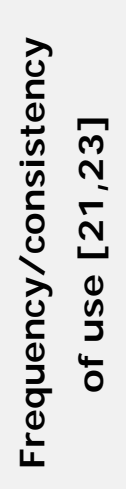 & 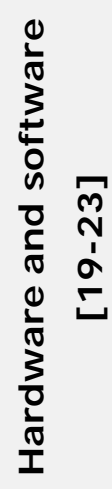 \\
\hline Atkison, 2007 [29] & & & $\mathbf{x}$ & $\mathbf{x}$ & & \\
\hline Bakken, 2006 [30] & & & $\mathbf{x}$ & $\mathbf{x}$ & & $\mathbf{X}$ \\
\hline Brockmeyer, 2013 [31] & & & & & & $\mathbf{x}$ \\
\hline Brooke, 1996 [32] & & & $\mathbf{x}$ & $\mathbf{x}$ & & \\
\hline Bunz, 2004 [33] & & & $\mathbf{x}$ & $\mathbf{x}$ & $\mathbf{x}$ & $\mathbf{x}$ \\
\hline Demiris, 2000 [34] & & & $\mathbf{x}$ & $\mathbf{x}$ & & $\mathbf{x}$ \\
\hline Finkelstein, 2012 [35] & $\mathbf{x}$ & & $\mathbf{x}$ & $\mathbf{x}$ & $\mathbf{x}$ & \\
\hline Henkemans, 2013 [36] & $\mathbf{x}$ & & & & & $\mathbf{x}$ \\
\hline Hudiberg, 1991-1996 [37-40] & & & $\mathbf{x}$ & $\mathbf{x}$ & & $\mathbf{x}$ \\
\hline Jay \& Willis, $1992[41]$ & & & $\mathbf{x}$ & & & \\
\hline Lewis, 1993 [42] & & & $\mathbf{x}$ & $\mathbf{x}$ & & $\mathbf{x}$ \\
\hline Lin, $2011[43]$ & & & & $\mathbf{x}$ & & $\mathbf{x}$ \\
\hline Martinez-Caro, 2013 [44] & $\mathbf{x}$ & & & & $\mathbf{x}$ & $x$ \\
\hline Montague, 2012 [45] & $\mathbf{x}$ & & $\mathbf{x}$ & $\mathbf{x}$ & & $\mathbf{x}$ \\
\hline Norman, 2006 [46] & $\mathbf{x}$ & & $\mathbf{x}$ & $\mathbf{x}$ & $\mathbf{x}$ & $\mathbf{x}$ \\
\hline Pluye, 2014 [47] & $\mathbf{x}$ & $\mathbf{x}$ & & $\mathbf{x}$ & $\mathbf{x}$ & $\mathbf{x}$ \\
\hline Schnall, 2011 [48] & $\mathbf{x}$ & $\mathbf{x}$ & $\mathbf{x}$ & $\mathbf{x}$ & & \\
\hline Tariman, 2011 [49] & $\mathbf{x}$ & & $\mathbf{x}$ & $\mathbf{x}$ & & $\mathbf{x}$ \\
\hline Wang, 2008 [50] & $\mathbf{x}$ & & $\mathbf{x}$ & $\mathbf{x}$ & & $\mathbf{x}$ \\
\hline Wehmeyer, 2008 [27] & & & & & & $\mathbf{x}$ \\
\hline Wolfradt, 2001 [51] & & $\mathbf{x}$ & & & & $\mathbf{x}$ \\
\hline Xie, 2013 [28] & $\mathbf{x}$ & & $\mathbf{x}$ & $\mathbf{x}$ & & $\mathbf{x}$ \\
\hline Yip, 2003 [52] & $\mathbf{x}$ & & & & & $\mathbf{x}$ \\
\hline
\end{tabular}


The 23 articles included in this review were mapped to the 12 identified concepts based on whether the instrument encompassed the concept. The most common constructs addressed by this set of measures were effectiveness, efficiency, hardware and software, perceived ease of use, satisfaction, and usability [19-23] (Tables 2 and 3). Interestingly, although eHealth is a communication technology, only three studies specifically address this aspect. Additionally, to identify potential gaps for future consideration, concepts included in the measures, but not identified in the 12 model concepts, were documented in the crosswalk (last column in Table 3 ). For example, stress, eHealth literacy, perceived necessity, and others emerged as concepts not identified in the review of existing technology use models. eHealth literacy is defined by Norman and Skinner [26] as "the ability to seek, find, understand, and appraise health information from electronic sources and apply the knowledge gained to addressing or solving a health problem." Wehmeyer [27] introduced three concepts: symbolism, esthetics, and perceived necessity. Symbolism reflects the meaning or status associated with the device (eg, having a mobile device may signify group membership or a certain social status). Esthetics refers to the appearance of the device (eg, the 
perceived beauty of the device may affect the attachment to the device). Finally, the perceived necessity of the device may affect attachment to the device, creating anxiety when the device is not accessible. Xie et al [28] addressed decision-making autonomy, defined as the level of decision making desired when information about health conditions is electronically available.

No instrument included a complete psychometric evaluation (Multimedia Appendix 2). The most frequently assessed property was internal consistency $(21 / 23,91 \%)$. None of the measures were assessed for sensitivity to change, but several authors indicated the instrument was not designed to assess change. Few measures were assessed for test-retest reliability $(4 / 23,17 \%)$ and only one instrument had been tested for interrater reliability. Testing for aspects of validity ranged from $48 \%(11 / 23)$ of measures tested for criterion, convergent, concurrent, or discriminant validity to $78 \%$ (18/23) reporting establishing content validity. Approximately half $(13 / 23,57 \%)$ reported how to score the instrument. Only six (26\%) assessed the readability of the instrument for end users, although all measures rely on patient self-report. 
Table 3, Concepts 7 to 12 identified in reviewed instruments $(\mathrm{N}=23)$

\begin{tabular}{|c|c|c|c|c|c|c|c|}
\hline \multirow[t]{2}{*}{ Article } & \multicolumn{6}{|c|}{ Concepts and model authors } & \multirow[b]{2}{*}{$\begin{array}{l}\text { Concepts } \\
\text { not } \\
\text { included } \\
\text { in models }\end{array}$} \\
\hline & 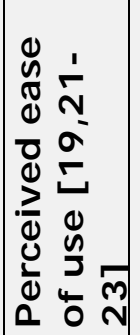 & 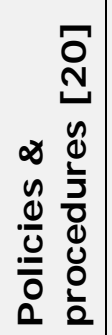 & 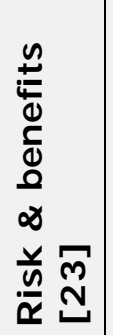 & 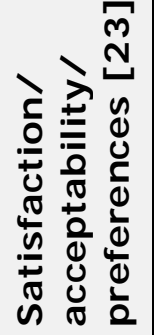 & 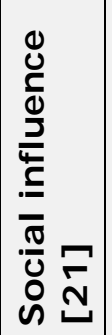 & 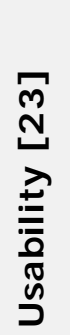 & \\
\hline Atkison, 2007 [29] & $\mathbf{x}$ & & & & & $\mathbf{x}$ & \\
\hline Bakken, 2006 [30] & $\mathbf{x}$ & & & $\mathbf{x}$ & & $\mathbf{x}$ & \\
\hline Brockmeyer, 2013 [31] & $\mathbf{x}$ & & $\mathbf{x}$ & $\mathbf{x}$ & & & \\
\hline Brooke, 1996 [32] & & & & $\mathbf{x}$ & & $\mathbf{x}$ & \\
\hline Bunz, 2004 [33] & $\mathbf{x}$ & & & $\mathbf{x}$ & & $\mathbf{x}$ & \\
\hline Demiris, 2000 [34] & $\mathbf{x}$ & & $\mathbf{x}$ & $\mathbf{x}$ & & $\mathbf{x}$ & \\
\hline Finkelstein, 2012 [35] & $\mathbf{x}$ & & & $\mathbf{x}$ & & & \\
\hline Henkemans, 2013 [36] & $\mathbf{x}$ & & $\mathbf{x}$ & $\mathbf{x}$ & & $\mathbf{x}$ & \\
\hline Hudiberg, 1991-1996 [37-40] & $\mathbf{x}$ & & $x$ & $\mathbf{x}$ & $\mathbf{x}$ & & Stress \\
\hline Jay \& Willis, 1992 [41] & $\mathbf{x}$ & & & & $\mathbf{x}$ & $\mathbf{x}$ & \\
\hline Lewis, $1993[42]$ & $\mathbf{x}$ & & $\mathbf{x}$ & $\mathbf{x}$ & & $\mathbf{x}$ & \\
\hline Lin, 2011 [43] & $\mathbf{x}$ & & & $\mathbf{x}$ & & $\mathbf{x}$ & \\
\hline Martinez-Caro, 2013 [44] & $\mathbf{x}$ & & $\mathbf{x}$ & $\mathbf{x}$ & & & \\
\hline Montague, 2012 [45] & $\mathbf{x}$ & & $\mathbf{x}$ & $\mathbf{x}$ & & $x$ & \\
\hline Norman, 2006 [46] & $\mathbf{x}$ & & & $\mathbf{x}$ & & & $\begin{array}{l}\text { eHealth } \\
\text { literacy }\end{array}$ \\
\hline Pluye, 2014 [47] & $\mathbf{x}$ & & & $\mathbf{x}$ & & & \\
\hline Schnall, 2011 [48] & $\mathbf{x}$ & & $\mathbf{x}$ & & & & \\
\hline Tariman, 2011 [49] & $\mathbf{x}$ & & & $\mathbf{x}$ & & & \\
\hline Wang, 2008 [50] & $\mathbf{x}$ & & & $\mathbf{x}$ & & $\mathbf{x}$ & \\
\hline Wehmeyer, 2008 [27] & $\mathbf{x}$ & & & $\mathbf{x}$ & & & $\begin{array}{l}\text { Symbolism; } \\
\text { esthetics; } \\
\text { perceived } \\
\text { necessity }\end{array}$ \\
\hline Wolfradt, 2001 [51] & & & & $\mathbf{x}$ & & & \\
\hline Xie, 2013 [28] & $\mathbf{x}$ & & & $\mathbf{x}$ & & $\mathbf{x}$ & $\begin{array}{l}\text { Decision- } \\
\text { making } \\
\text { autonomy }\end{array}$ \\
\hline Yip, 2003 [52] & & & & $\mathbf{x}$ & & & \\
\hline
\end{tabular}


Early instruments (prior to the year 2000) [32,37-42] focused on using a computer, reflecting early consumer adoption of personal computers. These measures are not specifically focused on "health" use. During the decade from 2000 to 2009, measures that focused on use of information technology related to health began to emerge, focusing primarily on telehealth $[30,34,52]$; other measures focused on eHealth literacy [46] and use of eHealth education [29]. Other concepts for which measures were developed included using the Internet [51], use of computers [33], use of mobile devices [27,50], and the effect of video games on engagement [31], although these measures did not specifically focus on "health." Since 2010, the frequency of "health" themes increased including communication between patients and providers [47,49], patient trust [45], preferences [28], satisfaction [35], and use of technology for care provision [48] or patient self-management $[36,48]$. One instrument also focused more generally on use of computers [43], and one focused on patient loyalty to online services [44]. 


\section{Discussion}

\section{Principal Findings}

Of the 23 articles reviewed, no instrument included a complete psychometric evaluation. The most frequently assessed property was internal consistency. Testing for aspects of validity ranged from $48 \%$ $(11 / 23)$ to $78 \%(18 / 23)$. Approximately half $(13 / 23,57 \%)$ reported how to score the instrument. Only six (26\%) assessed the readability of the instrument for end users, although all the measures rely on selfreport.

Common theoretical concepts addressed in the instruments were effectiveness, efficiency, hardware/software, perceived ease of use, and satisfaction. A notable exception is that only three instruments focused on communication. Conversely, we identified some concepts addressed in the instruments that have not been included in current theoretical models, including stress, esthetics, eHealth literacy, comfort, and decision-making autonomy. Current instruments require fuller evaluation of psychometric properties.

Measures that can be applied consistently across technologies and platforms are needed so that distinct platforms that serve the same purpose can be compared. For example, evaluation of an 
intervention to treat depression could utilize a standard measure of usability, regardless of whether it was a mobile app or Web-based (eg, "It took many tries before I knew how to use the key features of this technology" and "I found the layout of the features very intuitive"), regardless of the platform used to deliver the intervention (eg, mobile app or online program). Using these types of measures, investigators and others implementing eHealth technologies can compare technologies and use this information when selecting a technology.

Our review expands on the AHRQ compendium, which lists available measures but provides less detail about their other attributes. We also investigated whether the psychometric properties of the measures had been established, which is a critical information need when selecting a measure for research or evaluation. However, although most would agree that instruments with psychometric properties are very helpful, there may also be a role for using selfdeveloped questions that may more clearly and directly get at the target construct or a specific patient behavior. The AHRQ compendium is populated with many such instruments and future researchers should carefully consider the trade- offs of using investigator-developed question sets that may specifically address their question of interest 
versus a more validated instrument that may also need to be modified to fit an eHealth evaluation. Furthermore, investigators may want to consider instruments listed in the AHRQ compendium for further development and psychometric evaluation.

Implementation of eHealth technologies can involve substantial investment in terms of costs and effort. Research on eHealth has also increased dramatically over the past several years, yet studies rarely utilize common methods and/or instruments. The results of this project provide critical insights regarding existing eHealth instruments and identify gaps for which new instruments are needed. Use of common and psychometrically sound instruments can inform future studies so that the results from multiple studies can be compared and synthesized.

Although most the instruments identified in this review were published after the year 2000, rapidly changing technology makes instrument development challenging. Platform-agnostic measures need to be developed that focus on concepts important for use of any type of eHealth innovation. Instrument development as a research enterprise is typically undervalued, relative to more direct practicerelevant research. Instrument development can also be a complex and 
lengthy process. Thus, funding agencies should consider addressing this gap, given the persistent and expected growth in the deployment of technology to improve care processes and patient outcomes.

\section{Limitations}

We did not conduct a comprehensive search for all published uses of the identified instruments as it was beyond the scope of this study. The grey literature (eg, conference abstracts, dissertations, and unpublished studies) were not included in our review. Furthermore, the review potentially missed some published as well as unpublished measures based on keyword choice and/or elimination of articles through review of title or abstract. Finally, our choice of theoretical models used to analyze the selected articles may impose limitations on our findings.

\section{Conclusions}

Based on our review, we highlight some of the more useful measures that we believe could be useful in most technology studies. These include the eHealth literacy scale (eHEALS) [46], the ComputerEmail-Web Fluency Scale [33], and the System Usability Scale [32]. Additional research is needed to build and further refine measures of literacy such as the eHEALS or Computer-Email-Web Fluency Scale so 
that researchers have access to a validated measure of user's comfort with a target technology.

Development of a standard measure of the intuitiveness of the user interface would allow platform-agnostic comparisons between user interfaces (eg, two mobile apps for depression, or comparison of differences between a Web-based and mobile app). Finally, given the explosion of new technologies in the market focused on health behaviors, a standard measure of the relative advantage of a new technology feature when compared to prior methods and/or a standard measure of the degree to which new technology facilitates a target behavior (eg, weight loss, exercise, self-management techniques, or receipt of care) could provide important insights to inform technology adoption strategies.

Advances in eHealth offer tremendous potential to improve access to care, efficiency of care delivery processes, and overall quality. Significant resources are being invested in eHealth technologies, driven in part by meaningful use requirements. Consumer behavioral health interventions are increasingly being made available via multiple platforms (eg, computer vs mobile versions of interventions proven effective for in-person delivery). Identification of 
useful and valid measures to evaluate these interventions has important potential to contribute to improved implementation, clinical practice, and ultimately population health since insights gleaned from standardized measurement can directly inform system improvements and optimal implementation strategies. In addition, having better measures to evaluate implementation of eHealth technologies will help improve consumers' experiences with technologies and assess whether use of these technologies is making a measurable difference in quality of care or the patient experience. More longitudinal research will be needed to develop measures that more comprehensively address the wider frame of concepts important for the meaningful implementation of eHealth technologies.

\section{Acknowledgments}

The work reported here was supported by the Department of Veterans Affairs Health Services Research \& Development Quality Enhancement Research Initiative grant \#RRP12-496 and a Career Development Award (CDA 10-210) (Shimada). Assistance was provided by Amy Blevins, University of I owa Hardin Health Sciences Library, who assisted with the article search; Thomas Houston, MD, for review and input on project design; and Ashley McBurney for project 
assistance. Study sponsors provided funding, but had no role in the design or conduct of the study; sponsors did not review or approve the manuscript prior to submission. The views expressed in this article are those of the authors and do not necessarily represent the views of the Department of Veterans Affairs. 


\section{Abbreviations}

- AHRQ: Agency for Healthcare Research and Quality

- CI NAHL: Cumulative Index to Nursing and Allied Health Literature

- GEM: Grid-Enabled Measures

- HAPI : Health and Psychosocial Instruments

- PROMI S: Patient-Reported Outcomes Measurement System

- VA: Veterans Health Administration 


\section{References}

1. Eysenbach G. What is e-health? J Med Internet Res $2001 ; 3(2): \mathrm{e} 20$.

2. Klein-Fedyshin MS. Consumer Health Informatics--integrating patients, providers, and professionals online. Med Ref Serv Q $2002 ; 21(3): 35-50$

3. Calabretta N. Consumer-driven, patient-centered health care in the age of electronic information. J Med Libr Assoc 2002 Jan; 90(1):32-37.

4. Hogan T, Wakefield B, Nazi K, Houston T, Weaver F. Promoting access through complementary eHealth technologies:

recommendations for VA's Home Telehealth and personal health record programs. J Gen Intern Med 2011 Nov; 26 Suppl 2:628635.

5. Ahern D, Kreslake J, Phalen J. What is eHealth (6): perspectives on the evolution of eHealth research. J Med Internet Res 2006 $\operatorname{Mar} 31 ; 8(1): \mathrm{e} 4$

6. Elbert N, van Os-Medendorp H, van Renselaar W, Ekeland A, Hakkaart-van RL, Raat $\mathrm{H}$, et al. Effectiveness and costeffectiveness of ehealth interventions in somatic diseases: a 
systematic review of systematic reviews and meta-analyses. J Med Internet Res 2014 Apr 16; 16(4): e110.

7. Sarkar U, Lyles C, Parker M, Allen J, Nguyen R, Moffet H, et al. Use of the refill function through an online patient portal is associated with improved adherence to statins in an integrated health system. Med Care 2014 Mar; 52(3): 194-201.

8. Tang P, Overhage J, Chan A, Brown N, Aghighi B, Entwistle M, et al. Online disease management of diabetes: engaging and motivating patients online with enhanced resources-diabetes (EMPOWER-D), a randomized controlled trial. J Am Med Inform Assoc 2013 May 01;20(3):526-534.

9. Chen C, Garrido T, Chock D, Okawa G, Liang L. The Kaiser Permanente electronic health record: transforming and streamlining modalities of care. Health Affairs $2009 ; 28(2): 323-$ 333.

10. Nazi K, Hogan T, Woods S, Simon S, Ralston J. Consumer health informatics: engaging and empowering patients and families. In: Finnell JT, Dixon BE, editors. Clinical Informatics Study Guide: Text and Review. New York: Springer; 2016:459-500. 
11. de Jong CC, Ros W, Schrijvers G. The effects on health behavior and health outcomes of Internet-based asynchronous communication between health providers and patients with a chronic condition: a systematic review. J Med Internet Res 2014 Jan 16; 16(1): e19.

12. Black A, Car J, Pagliari C, Anandan C, Cresswell K, Bokun T, et al. The impact of eHealth on the quality and safety of health care: a systematic overview. PLoS Med 2011;8(1): e1000387.

13. Moser R, Hesse B, Shaikh A, Courtney P, Morgan G, Augustson E, et al. Grid-enabled measures: using Science 2.0 to standardize measures and share data. Am J Prev Med 2011;40(5 Suppl 2):S134-S143.

14. Cella D, Yount S, Rothrock N, Gershon R, Cook K, Reeve B, et al. The Patient-Reported Outcomes Measurement Information System (PROMIS): progress of an NIH Roadmap cooperative group during its first two years. Med Care 2007;45(5 Suppl 1):S3-S11.

15. Cella D, Riley W, Stone A, Rothrock N, Reeve B, Yount S, et al. The Patient-Reported Outcomes Measurement Information System (PROMIS) developed and tested its first wave of adult 
self-reported health outcome item banks. J Clin Epidemiol 2010;63(11): 1179-1194.

16. Lai J, Cella D, Choi S, J unghaenel D, Christodoulou C, Gershon $\mathrm{R}$, et al. How item banks and their application can influence measurement practice in rehabilitation medicine: a PROMIS fatigue item bank example. Arch Phys Med Rehabil 2011;92(10 Suppl): S20-S27.

17. Yost KJ, Eton DT, Garcia SF, Cella D. Minimally important differences were estimated for six Patient-Reported Outcomes Measurement Information System-Cancer scales in advancedstage cancer patients. J Clin Epidemiol 2011 May;64(5):507516.

18. Rothrock NE, Hays RD, Spritzer K, Yount SE, Riley W, Cella D. Relative to the general US population, chronic diseases are associated with poorer health-related quality of life as measured by the Patient-Reported Outcomes Measurement Information System (PROMIS). J Clin Epidemiol 2010 Nov; 63(11):11951204. 
19. Holden RJ, Karsh B. The technology acceptance model: its past and its future in health care. J Biomed Inform 2010 Feb; 43(1): 159-172.

20. Sittig D, Singh H. A new sociotechnical model for studying health information technology in complex adaptive healthcare systems. Qual Saf Health Care 2010 Oct; 19 Suppl 3:i68-i74.

21. Venkatesh V, Bala H. Technology Acceptance Model 3 and a research agenda on interventions. Decision Sci 2008; 39(2):273315.

22. Alexander G, Staggers N. A systematic review of the designs of clinical technology: findings and recommendations for future research. Adv Nurs Sci 2009;32(3):252-279.

23. Kim J, Park HA. Development of a health information technology acceptance model using consumers' health behavior intention. J Med Internet Res 2012 Oct 01;14(5): e133.

24. Streiner D, Norman G. Health Measurement Scales: A Practical Guide to Their Development and Use. Oxford: Oxford University Press; 1995. 
25. Rondan-Cataluña FJ, Arenas-Gaitán J, Ramírez-Correa PE. A comparison of the different versions of popular technology acceptance models. Kybernetes 2015;44(5): 788-805.

26. Norman C, Skinner H. eHealth literacy: essential skills for consumer health in a networked world. J Med Internet Res 2006 Jun $16 ; 8(2)$ : e9.

27. Wehmeyer K. User-device attachment scale: development and initial test. Int J Mob Commun 2008;6(3):280-295.

28. Xie B, Wang M, Feldman R, Zhou L. Internet use frequency and patient-centered care: measuring patient preferences for participation using the health information wants questionnaire. J Med Internet Res 2013;15(7): e132.

29. Atkinson NL. Developing a questionnaire to measure perceived attributes of eHealth innovations. Am J Health Behav $2007 ; 31(6): 612-621$.

30. Bakken S, Grullon-Figueroa L, Izquierdo R, Lee N, Morin P, Palmas W, IDEATel Consortium. Development, validation, and use of English and Spanish versions of the telemedicine satisfaction and usefulness questionnaire. J Am Med Inform Assoc 2006; 13(6):660-667. 
31. Brockmyer J, Fox C, Curtiss K, McBroom E, Burkhart K, Pidruzny J. The development of the Game Engagement Questionnaire: a measure of engagement in video game-playing. J Exp Soc Psychol 2009;45(4):624-634.

32. Brooke J. SUS: a quick and dirty usability scale. In: Jordan P, Thomas B, Weerdmeester B, McClelland I, Bristol P, editors. Usability Evaluation in Industry. London: Taylor \& Francis; 1996: 189-194.

33. Bunz U. The Computer-Email-Web (CEW) Fluency Scaledevelopment and validation. Int J Hum-Comput Interact $2004 ; 17(4): 479-506$.

34. Demiris G, Speedie S, Finkelstein S. A questionnaire for the assessment of patients' impressions of the risks and benefits of home telecare. J Telemed Telecare 2000;6(5):278-284.

35. Finkelstein SM, MacMahon K, Lindgren BR, Robiner WN, Lindquist $\mathrm{R}$, VanWormer A, et al. Development of a remote monitoring satisfaction survey and its use in a clinical trial with lung transplant recipients. J Telemed Telecare 2012; 18(1):42-46. 
36. Blanson Henkemans OA, Dusseldorp E, Keijsers J, Kessens J, Neerincx M, Otten W. Validity and reliability of the eHealth analysis and steering instrument. Med 20 2013;2(2): e8.

37. Hudiburg RA. Psychology of computer use: XXXIV. The Computer Hassles Scale: subscales, norms, and reliability. Psychol Rep 1995 Dec; 77(3 Pt 1): 779-782.

38. Hudiburg RA, Ahrens PK, Jones TM. Psychology of computer use: XXXI. Relating computer users' stress, daily hassles, somatic complaints, and anxiety. Psychol Rep 1994 Dec; 75(3 Pt 1):11831186.

39. Hudiburg RA, Jones TM. Psychology of computer use: XXIII. Validating a measure of computer-related stress. Psychol Rep $1991 ; 69(1): 179-182$.

40. Hudiburg RA, Necessary JR. Psychology of computer use: XXXV. Differences in computer users' stress and self-concept in college personnel and students. Psychol Rep 1996 Jun; 78(3 Pt 1):931937.

41. Jay G, Willis S. Influence of direct computer experience on older adults' attitudes toward computers. J Gerontol 1992 Jul; 47(4): P250-P257. 
42. Lewis J. IBM computer usability satisfaction questionnaires: psychometric evaluation and instructions for use. Int J HumComput Int 1995; 7(1):57-78.

43. Lin T. A computer literacy scale for newly enrolled nursing college students: development and validation. J Nurs Res $2011 ; 19(4): 305-317$.

44. Martínez-Caro E, Cegarra-Navarro J G, Solano-Lorente M. Understanding patient e-loyalty toward online health care services. Health Care Manage Rev 2013;38(1):61-70.

45. Montague E. Validation of a trust in medical technology instrument. Appl Ergon 2010;41(6):812-821.

46. Norman CD, Skinner HA. eHEALS: The eHealth Literacy Scale. J Med Internet Res 2006;8(4):e27.

47. Pluye P, Granikov V, Bartlett G, Grad R, Tang D, Johnson-Lafleur $J$, et al. Development and content validation of the information assessment method for patients and consumers. J MIR Res Protoc 2014 Feb 18;3(1):e7.

48. Schnall R, Bakken S. Testing the Technology Acceptance Model: HIV case managers' intention to use a continuity of care record 
with context-specific links. Inform Health Soc Care 2011

Sep; 36(3): 161-172.

49. Tariman J, Berry D, Halpenny B, Wolpin S, Schepp K. Validation and testing of the Acceptability E-scale for web-based patientreported outcomes in cancer care. Appl Nurs Res 2011 Feb; 24(1): 53-58.

50. Wang $\mathrm{Y}$, Wang $\mathrm{H}$. Developing and validating an instrument for measuring mobile computing self-efficacy. Cyberpsychol Behav $2008 ; 11(4): 405-413$.

51. Wolfradt U, Doll J. Motives of adolescents to use the internet as a function of personality traits, personal and social factors. J Educ Comput Res 2001;24(1): 13-27.

52. Yip M, Chang A, Chan J, MacKenzie A. Development of the Telemedicine Satisfaction Questionnaire to evaluate patient satisfaction with telemedicine: a preliminary study. J Telemed Telecare 2003;9(1):46-50. 


\section{CHAPTER 4 - STATE OF ADVANCE CARE}

\section{PLANNI NG AND PROVI DER USABI LITY OF ELECTRONIC END-OF-LIFE DOCUMENTS}

Diana R. Kennedy, MHA, MSHI ${ }^{1,2}$

${ }^{1}$ Department of Health Management and Informatics, University of Missouri, Columbia, Missouri, USA

2 MU Informatics Institute, University of Missouri, Columbia, Missouri, USA

\section{Abstract}

BACKGROUND: The 1991 Patient Self-Determination Act mandates healthcare organizations inform patients of their right to facilitate their own health care decisions through the creation of an advance directive ( $A D)$. With only one-third of Americans having an $A D$ [1] and $65-76 \%$ of physicians being unaware of ADs existence in the medical chart [2], information gathering is necessary to explore process improvements and solutions. OBJ ECTIVES: To establish a baseline of satisfaction and usability, among medical care providers within the University of Missouri Health System, with the current advance care planning ( $\mathrm{ACP}$ ) process and documentation within the electronic medical record (EMR). METHODS: Qualified healthcare 
professionals $(n=364)$ completed an 11-question online structured questionnaire designed to identify providers' retrieval of ACP documents, knowledge of ACP resources, barriers to wider use/recall of documents, and ranking of strategic initiatives priorities. RESULTS: While $64 \%$ of survey respondents had assisted patients with creating an advance directive (AD), $77 \%$ felt somewhat comfortable or less with assisting patients in creating or modifying their AD. Almost half (45\%) were unfamiliar with the current ACP resource book utilized within the health system. A majority ( $83 \%$ ) of respondents do not see or access ADs in the EMR and have experienced retrieval barriers. Only $12 \%$ reported the EMR location of ADs is easy to locate and access. DISCUSSION: Findings support the need for enhancements to the ACP process. This study identified the top-ranking utilization barriers and prioritization areas to direct future initiatives and innovations.

\section{Keywords}

Advance directive; electronic health record; information exchange; patient-centered care

\section{Background}

Individual preferences for end-of-life medical care are explored during the advanced care planning (ACP) process and defined within a 
document known as an advance directive (AD). ACP informs the creation of a written plan to speak for the patient when they become unable to speak for themselves due to cognitive impairment, delirium, or decision-making in patients who do not retain capacity [3]. Without an $A D$, individuals often receive extensive life-sustaining treatment that is often burdensome and undesirable, without regard for personal preferences [4]. With one in four adults in the United States (US) having an $A D$ [5], low adoption has been found to impact quality of life, patient values and choice, care coordination, cost of care, and the patient's family and loved ones grieving process [6]. Adherence to patient values and beliefs is valued by patients, loved ones, and health care providers through all episodes of care. However, a fundamental gap in the adoption of and education in ACP leads to undesirable and fragmented care coordination at a critical time point [7].

The Institute of Medicine Approaching Death (1997) and Dying in America (2014) reports echo ongoing key shortcomings in the dying process in America. These setbacks include the lack of: awareness in completing AD forms, clinician adoption of directives, institutional support, cultural and legal factors, evaluation of long-term effectiveness of ACP, application of shared decision making models, 
and integration into the EMR $[7,8]$. With sustained low adoption rates, consumer participation in the activity of ACP and familial impact is explored. The majority (62\%) of U.S. adults have given some or no thought to their wishes for end-of-life medical treatment [1]. One-third (35\%) having their wishes either formally or informally written down/discussed and $22 \%$ of the population aged 75 and older report no written wishes or discussions had occurred surrounding their end of life preferences [8]. While only $11 \%$ of adults having a valid ACD at the time of hospital admission [9]; the majority of adults (76\%) were willing to begin the process [9]. Reported barriers specific to AD form adoption and completion include fear and confusion about the documents [10], unfamiliarity with ADs and the process, understanding the clinical, legal, and ethical frameworks in which lifesustaining technologies would be used [11], and being too young [12]. It is suggested that ACP participation may be more successful if tied to wider future planning processes and redesigned AD formats [13]. Other contributors to low ACP adherence involve challenges with the present-day AD paper document. AD forms were found to be widely varying in retrieval method, language, structure, content, legal requirements, educational information, and storage location [6]. 
Additionally, the AD forms were deemed difficult to interpret by both patients in expressing their wishes and their providers in translating those wishes into a medical treatment plan [6]. For example, hypothetical situations in AD's may not be relevant to a patients' clinical presentation. Furthermore, until CMS' payment rule in 2016, no financial reimbursement existed for providers to spend valuable clinic time having end-of-life conversations with patients.

Lastly, significance exists in reconceptualizing ACP from the perspective of the patient. A traditional academic assumption of ACP is that ACP occurs within the context of the physician-patient relationship [14]. Surveyed patient-participants challenged this assumption in viewing ACP as a largely social process involving close loved ones and infrequently involving physicians [14]. Another traditional academic assumption is the focus on completing the written $A D$ forms whereas participants stated however patients were found to place more value on having the conversation with loved ones with the aim of preventing future familial burden [14].

\section{History of Advance Care Planning}

In the 1900s, half of individuals died at home [15]. In 1963, the American Heart Association formally endorsed the use of 
Cardiopulmonary Resuscitation [16]. In 1967, an attorney, Louis Kutner, drafted the first written living will [17]. In 1975, the notable Karen Ann Quinlan case went before the courts and, after nearly a decade in a vegetative state, her family was allowed to discontinue Karen Ann's mechanical ventilator [18]. In the 1980s, living will legislation was present in 39 states and the notable case of Nancy Cruzan was overturned at the U.S. Supreme Court level authorizing the removal of her feeding tube after years in a persistent vegetative state [19]. In December 1990, the Patient-Self Determination Act (PDSA) was passed by the U.S. Congress requiring health care institutions and home health agencies to provide written advance health care directive information to patients upon admission to their facility in efforts to inform them of their right to facilitate their own health care decisions, their right to accept or refuse medical treatment, and their right to make an advance health care directive [20]. Individual physicians and private clinics were exempt from this act and the act did not impact state laws as it had hoped [20]. Also in the 1990s, the American Medical Association and American College of Physicians promoted ACP as an essential component of medical care. Presently, one-third of deaths occur in hospitals and almost half occur 
in hospice [21]. Patient educational materials, supporting services, and documentation requirements of the paper forms continue to vary by facility and by state and largely have remained unchanged since the PDSA of 1990 [22]. In January 2016, the Center for Medicare and Medicaid Services began, for the first time, to reimburse qualified healthcare professionals for having end-of-life care planning conversations with Medicare patients; quality metrics have yet to be released. With this new stream of revenue for providing ACP services, attention to the reconceptualization and improvement in the ACP process is an opportunity that awaits.

\section{Health Economics and an Aging Population}

Health care expenditures for persons in their last year of life presently account for over $25 \%$ of Medicare spending [23]. By 2050, the population aged 80 and older is projected at 30.9 million [24], a $300 \%$ increase from the 11.3 million in 2010 [25]. This population is expected to be both more ethnically diverse and have more chronic conditions than previous generations [26]. With the rapid increase in the aging population, a core focus in geriatric care and population health planning is placed on engaging the population in conversations surrounding their values, beliefs, and wishes in considering and 
planning for care at the end-of-life. The capacity for providers to provide personalized medicine to patients, now and in the future, is reliant on stable avenues of communication between the patient and care provider(s) paired with technological capabilities robust enough to access, document, exchange, share, and store vital data retrieved as information.

\section{Methods}

A survey was distributed to providers within the University of Missouri Health System to establish a baseline of satisfaction and usability, with the current advance care planning (ACP) process and documentation within the EMR. Qualified healthcare professionals (nursing staff, social workers, physicians, residents, and fellows) attached to the palliative care, critical care, intensive care unit, internal medicine, or family medicine services and/or individuals who work with patients making end-of-life care plans, were invited to participate. An 11-question online structured questionnaire (Appendix

C) was developed to identify providers' retrieval of ACP documents, knowledge of ACP resources, barriers to wider use/recall of documents, and ranking of strategic initiatives priorities. Participation in the survey was voluntary and was open to providers from October- 
November 2015. Participants were provided a survey invitation

(Appendix D) that detailed the purpose of the research, procedures to be followed, time duration, statement of confidentiality, and voluntary participation of the research. Consenting participants will be enrolled in

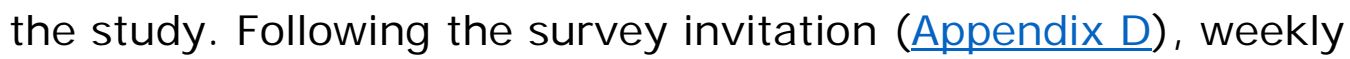
reminder emails (total of 2) were sent to invited participants. This survey was reviewed and approved with an Exempt application by the University of Missouri-Columbia Institutional Research Board under Project \#2003242 (Appendix E).

\section{Results and Discussion}

The survey had 364 respondents with self-reported occupations as nurse $(73 \%)$, physician ( $21 \%)$, social worker $(4 \%)$, clinical ethicist ( $1 \%)$, and other $(2 \%)$. While $64 \%$ of survey respondents $(N=364)$ had assisted patients with creating an AD, 77\% felt somewhat comfortable or less with assisting patients in creating or modifying their AD. Almost half $(45 \%)$ were unfamiliar with the Life Choices ACP resource book currently utilized within the health system, with $29 \%$ being somewhat familiar with the resource book. A majority ( $83 \%$ ) of respondents do not see or access ADs in the EMR, and have experienced retrieval barriers. Those who do see/access ADs in the EMR reported the 
documents are the appropriate length (39\%), too long (19\%), too short (16\%), or it depends on the situation (34\%). Only $12 \%$ reported the EMR location of ADs is easy to locate and access. Respondents were asked to review a list of 19 barriers to proper review and utilization of $A D s$ and report how frequently they experience the barrier. Reponses were given a value of always (4), sometimes (3), rarely (2), or never (1), with the top-ranking six barriers emerging as: 1) Cannot locate document in EMR; 2) Applicability to current clinical presentation; 3) Family conflict with AD wishes; 4) Outside records not in EMR; 5) Difficulty advocating wishes to the care team; and 6) Difficulty translating wishes into the care plan (Table 1 ).

\# Barriers to Utilization

1 Cannot locate document in EMR

2 Applicability to current clinical presentation

3 Family/guardian/spokesperson conflict with AD wishes

4 Outside records not in EMR (e.g., nursing home records)

5 Difficulty advocating wishes to care team

Table 1, Barriers to Advance Directive Utilization

Next, respondents ranked 12 proposed $A D$ improvement areas in terms of high priority, medium priority, low priority, or not a priority with the top-ranking six prioritization areas emerging as: 1) General

Scale Total 270 251 247 246 227 
population education on ACP; 2) Provider education/training on endof-life discussions with patients and/or surrogates; 3) A computerized program to guide patients/users through the ACP process; 4) Provider education/training on completion of the AD; 5) Improved workflow/ ownership of patient education with EOL medical decision-making; and 6) Patient's ability to upload their own AD and/or DPOA documents directly to their medical record (Table 2).

Table 2, Priority Improvement Areas

\begin{tabular}{|l|l|c|}
\hline \# & Priority I mprovement Areas & Scale Avg. \\
\hline 1 & General population education on ACP & 179 \\
\hline 2 & $\begin{array}{l}\text { Provider education/training on end-of-life discussions with } \\
\text { patients and/or surrogates }\end{array}$ & 171 \\
\hline 3 & $\begin{array}{l}\text { A computerized program to guide patients/users through } \\
\text { the ACP process }\end{array}$ & 169 \\
\hline 4 & \begin{tabular}{l} 
Provider education/training on completion of the ACD \\
\hline 5
\end{tabular} & $\begin{array}{l}\text { Improved workflow/ownership of patient education with } \\
\text { EOL medical decision-making. }\end{array}$ \\
\hline 6 & $\begin{array}{l}\text { Patients ability to upload their own ACD and/or DPOA } \\
\text { documents directly to their medical record }\end{array}$ & 168 \\
\hline
\end{tabular}

Results from the provider questionnaire support the need for improvement to the ACP process, directed by the health system, focused at both the patient and provider-level. 


\section{Conclusion and Future Directions}

This paper aims to summarize the current state of advance care planning in the U.S. and the opportunities that exist to improve endof-life care. The provider survey identified the most prevalent barriers to $A D$ utilization within the EMR and in identifying prioritization areas for improvement of advance care planning within the health system. Future clinical research opportunities are discussed below to guide further improvements and innovations.

\section{Computer Decision-Aid}

Over the past decade, research of ACP in the U.S. has increased, however, few published studies have evaluated user preferences and outcomes of a web-based ACP application [27-29]. These studies reported successful interventions with high satisfaction [27], high accuracy [28-29], and where patient-participants agreed (84\%) with the physician translation of their directive [28]. While limited, these study results suggest the potential for continued innovation in the delivery and evaluation of computer-based ACP. In harmony, shifting towards an interactive web-based software could support the integration for real-time transfer of information into the EMR. This future opportunity is significant as, if developed as a patient-centered 
education framework, could reach a broader population than the existing low impact educational tools that are used and hosts the opportunity to capture and translate patient preferences into individualized medical action that is accessible to medical providers across health systems.

\section{EMR \& Education}

Further data integration and retrieval efforts are necessary to address provider utilization barriers. Future opportunities exist to both improve the current process and transform the manner in which ADs are created, stored, and retrieved by the patient and the medical team. These utilization barriers require improvements within the EMR and/or health information exchange(s) and multimodal educational initiatives with the general public and medical provider teams. By improving the $A D$ exchange environment, patient-provider communication is enhanced through the use of health information technology with aims to more clearly and effectively articulate patient values and choice to the medical team. Enabling capabilities for future private insurance plan reimbursements with qualities metrics tied to reimbursement should be taken into consideration. The identified improvement areas support the societal trend of shifting from paper- 
based AD forms towards the use of web-based technology. Exchanging this information electronically empowers health information professions to mine population data for completion, preferences, outcomes, length of stay, cost of medical care, familial satisfaction with care, etc. The capture and analysis of this information, currently not available within most systems, enables broader population health planning.

\section{Future Skills to be Gained}

From the patients' perspective, skills to be gained from processbased improvements and innovation include improving the knowledge translation of ACP choices, increasing the ease of completion of ACP documents, and improving individual ownership of ACP decisions and choices. From the perspective of the provider, skills will be gained by sharing vetted methods which increase adoption of patient-preferred tools, leading to enhanced patient-provider ACP conversations and overall understanding of individualized goals of care. Furthermore, enabling real-time provider access to a document consistent with patient values and with greater alignment and consistency with patient belief structures will impact the delivery of patient-centered care in medically necessary situations. Broader skills to be gained include 
gaining an understanding of how clinical ACP documentation and provider-based ACP education can better align with adoption, learning, documentation, completion preferences of patients. With this understanding, the quality and applicability of clinical documentation, the clinical workflow, and storage and retrieval of documents within the health record may be improved. These advantages and innovations aim to support an overall promise in shifting the engagement, utility, conversation and translation of ACP documentation and decisions towards a pointed and personalized avenue in which patients are motivated and satisfied to participate. 


\section{Definition of Terms}

Advance Directive: Also known as advance healthcare directive, living will, or similar.

Advance care planning: The process of thinking and planning about your future death.

Advance care plan: A written summary of your wishes, preferences and decisions about your end of life care.

Best interest: A process clinicians use to assess, ascertain, and decide what is in the best interests for care for a person if they cannot say so themselves. Advance care planning tools such as advance directives and/or their durable power of attorney may be used to gain as much information as possible about a person wishes.

DNR: Do not attempt cardio-pulmonary resuscitation.

Durable Power of Attorney (DPOA): A legally appointed surrogate decision-maker.

End of life care: An approach to care for when somebody may be in the last years, year, months, weeks or days of life.

Hospice care: An approach to care (as in palliative care) which includes helping people who have an incurable illness live well until they die through person-centered care. Includes inpatient and 
outpatient care, outreach, pain/symptom control, family support, conversations, education, and research.

Palliative care: A multi-professional approach to care for those who have an incurable illness (as in hospice care) with a focus on physical, emotional, psychological, spiritual, and social support. Takes part in any setting and for those with cancer or non-cancer diagnoses.

Patient-centered care: An individualized approach to care which treats the patient as a unique individual.

Person-centered care: An approach to care where a provider aims to understand the person (patient) within the context of their own social relationships, networks, and lived experiences. 


\section{References}

1. Pew Research Center, Views on end-of-life medical treatments. November 2013.

2. Kass-Bartelmes, B.L. and R. Hughes, Advance care planning. J ournal of Pain \& Palliative Care Pharmacotherapy, 2004. 18(1): p. 87-109.

3. Seymour J, Almack K, Kennedy S. Implementing advance care planning: a qualitative study of community nurses' views and experiences. BMS Palliative Care. 2010;9(4).

4. Institute of Medicine Committee on Care at the End of Life. Approaching death: improving care at the end of life.

Washington, DC; 1997.

5. Kirschner K. When written advance directives are not enough. Clinics in Geriatric Medicine. 2005;21: 193-209.

6. Thompson T, Barbour R, Schwartz L. Adherence to advance directives in critical care decision making: vignette study2003 2003-10-30 10:26:14. 1011 p.

7. Meghani Shea. Policy brief: The Institute of Medicine report Dying in America: I mproving quality and honoring individual 
preferences near the end of life. Nursing Outlook.

$2014 ; 63(1): 51-9$.

8. Field MJ , \& Cassel, C. K. Approaching death: improving care at the end of life. Committee on Care at the End of Life. Division of Health Care Services, Institute of Medicine National Academy of Sciences Chicago. 1997.

9. Muthappan P, Forster H, Wendler D. Research Advance Directives: Protection or Obstacle? American Journal of Psychiatry. 2005; 162(12):2389-91.

10. Marchand L, Cloutier VM, Gjerde C, Haq C. Factors influencing rural Wisconsin elders in completing advance directives. WMJ . $2001 ; 100(9): 26-31$.

11. Seymour J. Technology and "natural death": a study of older people. Zeitschrift fur Gerontologie und Geriatrie. $2003 ; 36(5): 339-46$.

12. Pollack KM, Morhaim D, Williams MA. The public's perspectives on advance directives: implications for state legislative and regulatory policy. Health Policy. 2010;96(1):57-63. 
13. White B, Tilse C, Wilson J, Rosenman L, Strub T, Feeney R, et al. Prevalence and predictors of advance directives in Australia. Internal Medicine J ournal. 2014;44(10): 975-80.

14. Singer P, Martin D, Lavery J, Thiel E, Kelner M, Mendelssohn D. Reconceptualizing Advance Care Planning From the Patient's Perspective. Arch Intern Med. 1998;158(8):879-84.

15. Cassel C, Demel B. Remembering death: public policy in the USA. Journal of the Royal Society of Medicine. 2001;94(9):4336.

16. American Heart Association. Highlights of the History of Cardiopulmonary Resuscitation (CPR) 2006 [Available from: www.americanheart.org.

17. Kutner L. Due Process of Euthanasia: The Living Will, A Proposal. Indiana Law Journal. 1969;44(4).

18. Quinlan J. Karen Ann Quinlan. Trends Health Care Law Ethics. 1993; 8: 65-8.

19. Annas G. Nancy Cruzan and the right to die. New England Journal of Medicine. 1990;323(10):670-3.

20. American Bar Association. Health Care Advance Directives- What is the Patient Self-Determination Act? n.d. 
21. Centers for Disease Control and Prevention. Deaths and mortality Atlanta, GA. 2016.

22. Brinkman-Stoppelenburg A, Rietjens JA, van der Heide A. The effects of advance care planning on end-of-life care: A systematic review Palliative Medicine. 2014;28(8): 1000-25.

23. Riley G, Lubitz J. Long-term trends in medicare payments in the last year of life. Health Services Research. 2010;45(2):565-76.

24. U.S. Census Bureau PD. 2012 National Population Projections: Summary Tables, Projections of the population by age and sex for the United States: 2015 to 2060 (NP2012-T12). 2012.

25. U.S. Census Bureau PD. Annual Estimates of the Resident Population by Sex and Five-Year Age Group for the United States: April 1, 2010 to July 1, 2011 (NC-EST2011-01). 2011.

26. Medicare Payment Advisory Commission (MedPac). Medicare Payment Policy. Washington, DC; 2014.

27. Green MJ, Levi BH. Development of an interactive computer program for advance care planning. Health Expect. $2009 ; 12(1): 60-9$. 
28. Schubart JR, Levi BH, Camacho F, Whitehead M, Farace E, Green MJ. Reliability of an interactive computer program for advance care planning. J Palliat Med. 2012;15(6):637-42.

29. Hossler C, Levi BH, Simmons Z, Green MJ. Advance care planning for patients with ALS: feasibility of an interactive computer program. Amyotroph Lateral Scler. 2011;12(3):172-7. 


\section{CHAPTER 5 - CONCLUSION}

Interventional informatics, a sub-specialty of health informatics, is an approach which supports health information professionals to apply data-driven innovations focused on generating unique evidencegathering approaches which contribute to the coordination and delivery of health care and the management and insight of population health. The research presented in this thesis aims at producing innovations and knowledge, from three separate studies, that drive the field of health informatics forward. Each of these studies is linked in identifying, evaluating, and/or developing interventions with potential to shift current foci to robust processes that support the exchange of information, quality of programmatic services, measure outcomes of patient-facing applications, improvements in patient care, improved alignment between self-directed continuous quality improvement projects and their organizational initiatives and garner efficiencies and effectiveness of care delivery protocols. Through a greater understanding of these opportunities, barriers, application, innovation, and outcomes facing health information technology professionals, we are able to better allocate resources to current and future industry needs. 
First, the "Building and Launching an Online Quality Improvement Information Exchange for Home Visiting Programs in Missouri" chapter describes the characteristics, development, build, and launch of a quality improvement practice exchange virtual environment for use by home visiting agencies in Missouri and present results of three usability pilot tests and the site launch. Pilot testing results were overall positive, desirable, and vital to improving the site prior to the full-launch. The majority of reviewers stated they would access and use the learning materials (87\%), use the site for completing CQII (80\%), and reported that the site will benefit their work teams in addressing agency challenges (66\%). The majority of reviewers also approved of the developed fidelity assessment: as, easy to use $(79 \%)$, having a clear purpose $(86 \%)$, providing value in selfidentification of CQII (75\%), and recommendations were appropriate (79\%). The System Usability Scale (SUS) score increased (10\%) between pilot groups 2 and 3, with a mean SUS score of 71.6, above the U.S. average of 68 . The site launched to 60 invited users; the majority (67\%) adopted and used the site. Development of the Gateway environment aimed to complement the existing MIECHV CQI framework. We were successful in meeting these aims by: 1) adding 
CQI elements that are missing or ineffective, such as standardized training tutorials, webinars, and structured CQI project forms, 2) adding elements for CQI identification and program evaluation, such as the "Program Fidelity and CQI Assessment" and 3) offering LIAs a network to share CQI experiences and collaborate at a distance, through avenues such as the discussion forums and the CQI Storyboard Library. We built a stable site that successfully: achieved an above average (71.6) usability score, developed an acceptable (78\% overall satisfaction) fidelity self-assessment tool to prioritize CQI activities, and concluded with a site adoption rate of $67 \%$ averaging 29 page views per day.

Through the development and launch of the site, lessons were learned. First, the site design is fluid and appears to harness the necessary adaptability to change as the programs and/or end-users change. Second, encouraging open communication between end-users, developers, and program administrators was a necessary activity in garnering shared vision and ownership of the site. Third, further pilots are necessary to understand how individuals are motivated to use the site. Last, the site would benefit from storing and sharing data, ideally real-time data, where end-users could benchmark their performance. 
This data integration, powered by informatics frameworks, requires a shift in program willingness to share the data both with the site and with all site users.

Limitations to this study exist. First, significant run-time is essential for adoption and utility of any new technology. The short run (12 weeks) did not allow adequate time for a pilot test where generalizable impact to larger user populations could be assured. Further and lengthier pilots are necessary to gather and analyze key usage trends over time. Second, a lack of prior studies on comparable web-based tools pose challenges in the ability to set baseline measurements of whether the web-based CQI intervention achieved meaningful success. Lastly, from conceptualizing a problem for improvement to measurement of current to future-state change to monitoring and maintaining the change, there is a strong reliance on certifiable and accessible program performance data. Due to data reporting system barriers, external and independent from the site, shared performance data was unable to be integrated as a site resource.

Overall, the Gateway site adds value to the application of quality improvement beyond the conducted study. Funding has been secured 
for site expansion to programs and agencies beyond the built population with pilot feasibility study in progress with results to be shared in the near future.

Second, chapter three entitled "Psychometric Properties of Patient-Facing eHealth Evaluation Measures: Systematic Review and Analysis" reviews eHealth technology instruments for outcomes and evaluation components geared towards patient outcomes. The search strategy yielded 47,320 articles from six databases, which after review for inclusion, led to 23 articles included in this review. Of these, 16 described an instrument and six used an instrument; however it was found that none included a complete psychometric evaluation. Then, the 23 instruments were categorized, leading to twelve emerging concepts: clinical content, communication, effectiveness, efficiency, frequency/consistency of use, hardware and software, perceived ease of use, policies and procedures, risk and benefits, user preferences, social influence, and usability. Three measures (eHEALS, ComputerEmail-Web Fluency Scale, and System Usability Scale) emerged as measures which may benefit technology studies most; however work remains to build and further refine these measures. 
Limitations of this study include excluding grey literature (eg, conference abstracts, dissertations, and unpublished studies), possible removal of articles based on missed keyword and/or through review of title or abstract. Last, the authors' choice of theoretical models used to analyze the selected articles may impose limitations on the findings.

Overall, this review highlights important gaps in the availability of psychometrically sound measures to evaluate eHealth technologies. While advances in eHealth promise improved access to care and overall quality, further work is necessary. Future work may surround developing: a measure of the relative advantage of a new technology/features when compared to prior methods, a measure of the degree to which new technology/features facilitates a change (eg, behavioral, physical), a measure to evaluate the platform delivery method (eg, desktop, mobile, kiosk), and a measure to evaluate implementation of eHealth technologies.

Third, the "State of Advance Care Planning and Provider Usability of Electronic End-of-Life Documents" chapter describes (1) a brief history of advance care planning (ACP) in the United States (U.S.), (2) the current state of ACP in the U.S., (3) presents results of a health provider survey that identified barriers to utilization of end-of-life care 
preference documents stored in the electronic medical record (EMR), and (4) presents results of a health provider survey that identified prioritization areas where improvements to the EMR technology, clinical workflow and process, and the delivery of education to both providers and patients should be made.

The provider survey found that the current HIT lacks movement towards an infrastructure of capturing patient preferences that can potentially translate to medical decision-making in end-of-life care. The survey had 364 respondents with self-reported occupations as nurse $(73 \%)$, physician $(21 \%)$, social worker $(4 \%)$, clinical ethicist ( $1 \%)$, and other $(2 \%)$. While $64 \%$ of survey respondents $(N=364)$ had assisted patients with creating an advance directive (AD), $77 \%$ felt somewhat comfortable or less with assisting patients in creating or modifying their AD. Almost half (45\%) were unfamiliar with the Life Choices ACP resource book currently utilized within the health system, with $29 \%$ being somewhat familiar. A majority ( $83 \%$ ) of respondents do not see or access ADs in the EMR, and have experienced retrieval barriers. Those who do see/access ADs in the EMR reported the documents are the appropriate length (39\%), too long (19\%), too 
short (16\%), or it depends on the situation (34\%). Only $12 \%$ reported the EMR location of ADs is easy to locate and access.

Within a large health system, it was necessary to identify the most prevalent barriers to utilization of the electronically-stored $A D$ and identify improvement areas/goals that the majority of respondents agreed with. Based on respondent ranking, the top-ranking six barriers to utilization of the AD emerged as: 1) Cannot locate document in EMR; 2) Applicability to current clinical presentation; 3) Family conflict with AD wishes; 4) Outside records not in EMR; 5) Difficulty advocating wishes to care team; and 6) Difficulty translating wishes into care plan. The top-ranking six prioritization areas for improvement emerged as: 1) General population education on ACP; 2) Provider education/training on end-of-life discussions with patients and/or surrogates; 3) A computerized program to guide patients/users through the ACP process; 4) Provider education/training on completion of the AD; 5) I mproved workflow/ ownership of patient education with EOL medical decision-making; and 6) Patient's ability to upload their own AD and/or DPOA documents directly to their medical record.

Overall, results from the provider questionnaire support the need for improvement to the ACP process, directed by the health system, 
focused at both the patient and provider-level. Future research opportunities exist to guide further improvements and innovations in end-of-life care research and the overall experience. These opportunities include: 1 ) the adoption of a web-based ACP application for users to create, share, and transfer their unique end-of-life care preferences to their health provider/system of choice, 2) improvements to the EMR in how ADs are stored, indexed, and retrieved by the medical team, and 3) patient- and provider-level education (eg, goals of care, billing requirements, AD legal requirements, etc.), and 4) a standardized template for providers to document their ACP conversations with patients built for billing, sharing across health systems, and for retrieval by the medical team. With the potential to directly impact public health with the delivery of an innovative approach to the reinvention of the ACP activity, the health care industry will be better prepared to deliver patient-centered care across health systems.

In conclusion, the main contribution of this research to the field of health informatics is garnered from its' willingness to examine traditional pathways for knowledge discovery and when applied, innovative technologies, to better understand user-adoption, utility, 
usability and feasibility of these technologies and the outcome of exposure to the technologies developed and evaluated from a multidimensional perspective of person, team, system, and outcomes. 


\section{APPENDIX}

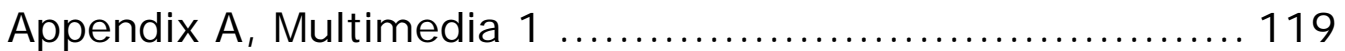

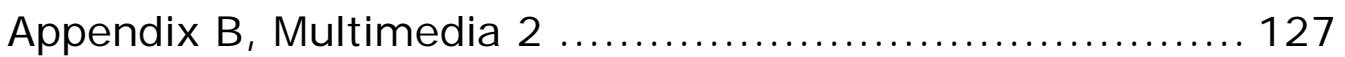

Appendix C, Provider Questionnaire ....................... 148

Appendix D, Consent and Recruitment Email for "Providers

Survey on Advance Care Directives" Survey............ 153

Appendix E, Institutional Review Board Approval ............ 154 


\section{Appendix A: Multimedia 1}

\begin{tabular}{|l|l|}
\hline SET A: PLATFORMS & LOCATI ON \\
\hline Cell phone & Title/Abstract \\
\hline Computer & Title/Abstract \\
\hline Mobile phone & Title/Abstract \\
\hline Digital health & Title/Abstract \\
\hline Electronic communication* & Title/Abstract \\
\hline Email & Title/Abstract \\
\hline “Electronic mail” & MESH \\
\hline Gamification & Title/Abstract \\
\hline Gaming & Title/Abstract \\
\hline “Video games” & MESH \\
\hline Interactive voice response & Title/Abstract \\
\hline Internet & Title/Abstract \\
\hline Kiosk & Title/Abstract \\
\hline Mobile application* & Title/Abstract \\
\hline Online communit* & Title/Abstract \\
\hline Online forum* & Title/Abstract \\
\hline Online support group* & Title/Abstract \\
\hline Patient portal* & Title/Abstract \\
\hline
\end{tabular}




\begin{tabular}{|l|l|}
\hline SET A: PLATFORMS & LOCATI ON \\
\hline Personal digital assistant* & Title/Abstract \\
\hline Remote monitoring & Title/Abstract \\
\hline Secure Messaging & Title/Abstract \\
\hline Smart phone* & Title/Abstract \\
\hline Social networking & MESH \\
\hline Social network* & Title/Abstract \\
\hline Telecommunication & Title/Abstract \\
\hline “Telecommunications” & MESH \\
\hline Telemonitoring & Title/Abstract \\
\hline Telephone & Title/Abstract \\
\hline Text messaging & Title/Abstract \\
\hline Texting & Title/Abstract \\
\hline SMS & Title/Abstract \\
\hline User interface & Title/Abstract \\
\hline Video conferencing & Title/Abstract \\
\hline Web & Title/Abstract \\
\hline Wireless & Title/Abstract \\
\hline “Wireless technology” & MESH \\
\hline World wide web & Title/Abstract \\
\hline
\end{tabular}




\begin{tabular}{|l|l|}
\hline SET A: PLATFORMS & LOCATI ON \\
\hline “Computers, handheld" & MESH \\
\hline “Cellular Phone" & MESH \\
\hline “computers" & MESH \\
\hline “Internet" & MESH \\
\hline “telephone" & MESH \\
\hline “text messaging" & MESH \\
\hline “online systems" & MESH \\
\hline
\end{tabular}

\begin{tabular}{|l|l|}
\hline SET B: MEASUREMENT & LOCATI ON \\
\hline Instrument & Title/Abstract \\
\hline Interviews & Title/Abstract \\
\hline Interview & Title/Abstract \\
\hline Measure & Title/Abstract \\
\hline “Outcome assessment (health care)" & MESH \\
\hline “Process assessment (health care)" & MESH \\
\hline Psychometrics & Title/Abstract \\
\hline Psychometric & Title/Abstract \\
\hline Questionnaire & Title/Abstract \\
\hline Reliability & Title/Abstract \\
\hline
\end{tabular}




\begin{tabular}{|l|l|}
\hline SET B: MEASUREMENT & LOCATI ON \\
\hline “Reproducibility of results" & MESH \\
\hline Scale & Title/Abstract \\
\hline Survey & Title/Abstract \\
\hline Tool & Title/Abstract \\
\hline “Validation studies" & Publication Type \\
\hline Validation & Title/Abstract \\
\hline Validity & Title/Abstract \\
\hline “Questionnaires" & MESH \\
\hline “Evaluation studies as topic” & MESH \\
\hline “Evaluation studies” & Publication Type \\
\hline
\end{tabular}




\begin{tabular}{|c|c|}
\hline $\begin{array}{l}\text { SET C: FUNCTI ONS/ } \\
\text { I NFORMATI ON USE }\end{array}$ & LOCATI ON \\
\hline “computer literacy” & Title/Abstract \\
\hline consumer health informatics & Title/Abstract \\
\hline “care coordination" & Title/Abstract \\
\hline eHealth literacy & Title/Abstract \\
\hline e-health literacy & Title/Abstract \\
\hline information seeking & Title/Abstract \\
\hline “health literacy" & MESH \\
\hline heuristics & Title/Abstract \\
\hline human computer interaction & Title/Abstract \\
\hline "information literacy" & MESH \\
\hline "meaningful use" & MESH \\
\hline participatory design & Title/Abstract \\
\hline patient access & Title/Abstract \\
\hline patient activation & Title/Abstract \\
\hline patient engagement & Title/Abstract \\
\hline patient-provider communication & Title/Abstract \\
\hline Doctor-patient communication & Title/Abstract \\
\hline $\begin{array}{l}\text { personal health information } \\
\text { management }\end{array}$ & Title/Abstract \\
\hline self-management; & Title/Abstract \\
\hline
\end{tabular}




\begin{tabular}{|c|c|}
\hline $\begin{array}{l}\text { SET C: FUNCTI ONS/ } \\
\text { I NFORMATI ON USE }\end{array}$ & LOCATION \\
\hline self management & Title/Abstract \\
\hline “social support” & MESH \\
\hline usability & Title/Abstract \\
\hline user centered design & Title/Abstract \\
\hline user-centered design & Title/Abstract \\
\hline “case management” & MESH \\
\hline “user-computer interface” & MESH \\
\hline “consumer participation” & MESH \\
\hline "patient access to records" & MESH \\
\hline "health communication" & MESH \\
\hline "health information management" & MESH \\
\hline “self care" & MESH \\
\hline case management & MESH \\
\hline “information seeking behavior” & MESH \\
\hline "attitude to computers" & MESH \\
\hline “patient satisfaction” & MESH \\
\hline “patient preference” & MESH \\
\hline "patient acceptance of health care" & MESH \\
\hline “health promotion” & MESH \\
\hline
\end{tabular}




\begin{tabular}{|l|l|}
\hline $\begin{array}{l}\text { SET D: HEALTHCARE } \\
\text { OCCUPATI ONS }\end{array}$ & LOCATI ON \\
\hline Health* & Title/Abstract \\
\hline Medicine & Title/Abstract \\
\hline Nurse* & Title/Abstract \\
\hline Dentis* & Title/Abstract \\
\hline Psychiatr* & Title/Abstract \\
\hline Pharmacist* & Title/Abstract \\
\hline Pharmacy & Title/Abstract \\
\hline Social work* & Title/Abstract \\
\hline “Health occupations” & MESH \\
\hline “Delivery of healthcare” & MESH \\
\hline Psychology* & Title/Abstract \\
\hline Medical & Title/Abstract \\
\hline Nursing & Title/Abstract \\
\hline
\end{tabular}




\begin{tabular}{|l|l|}
\hline $\begin{array}{l}\text { SET E: EHEALTH/ } \\
\text { TELEMEDI CI NE }\end{array}$ & LOCATI ON \\
\hline eHealth & Title/Abstract \\
\hline e-health & Title/Abstract \\
\hline mHealth & Title/Abstract \\
\hline m-health & Title/Abstract \\
\hline “Health records, personal” & MESH \\
\hline Telehealth & Title/Abstract \\
\hline Telemedicine & Title/Abstract \\
\hline Telepatholog* & Title/Abstract \\
\hline Teleradiolog* & Title/Abstract \\
\hline Telenur* & Title/Abstract \\
\hline Teledentist* & Title/Abstract \\
\hline “Telemedicine” & MESH \\
\hline “Therapy, computer-assisted” & MESH \\
\hline
\end{tabular}




\section{Appendix B: Multimedia 2}

\begin{tabular}{|c|c|c|c|}
\hline Citation & Atkinson, 2007 & $\begin{array}{l}\text { Bakken et al., } \\
2006\end{array}$ & $\begin{array}{c}\text { Brockmyer, et al., } \\
2009\end{array}$ \\
\hline $\begin{array}{l}\text { Instrument } \\
\text { name }\end{array}$ & No name & No name & $\begin{array}{l}\text { Game Engagement } \\
\text { Questionnaire }\end{array}$ \\
\hline Construct & $\begin{array}{l}\text { Perceived } \\
\text { characteristics of } \\
\text { an eHealth } \\
\text { education } \\
\text { innovation }\end{array}$ & $\begin{array}{l}\text { Satisfaction with } \\
\text { telemedicine }\end{array}$ & $\begin{array}{l}\text { Engagement of } \\
\text { players during } \\
\text { violent video } \\
\text { games; constructs } \\
\text { examined include } \\
\text { flow and } \\
\text { psychological } \\
\text { absorption }\end{array}$ \\
\hline $\begin{array}{l}\text { Theoretical } \\
\text { foundation }\end{array}$ & $\begin{array}{l}\text { Diffusion of } \\
\text { innovations }\end{array}$ & NR & $\begin{array}{l}\text { Rasch approach to } \\
\text { measure } \\
\text { development }\end{array}$ \\
\hline $\begin{array}{l}\text { Modification of } \\
\text { another } \\
\text { instrument }\end{array}$ & Yes & NR & $x_{1}$ \\
\hline \# items & 30 & 21 & NR \\
\hline Item types & Likert-type & Likert-type & yes/no questions \\
\hline $\begin{array}{l}\text { Administration } \\
\text { time }\end{array}$ & NR & NR & ק \\
\hline $\begin{array}{l}\text { Item } \\
\text { development }\end{array}$ & $\begin{array}{l}\text { Re-worded items } \\
\text { from a previous } \\
\text { study by Bolton } \\
\text { (1983) }\end{array}$ & $\begin{array}{l}\text { Selected } 51 \text { items } \\
\text { from other surveys; } \\
\text { telemedicine } \\
\text { experts prioritized } \\
\text { items \& suggested } \\
\text { new ones; } \\
\text { developed English } \\
\text { and Spanish } \\
\text { versions }\end{array}$ & $\begin{array}{l}\text { 1) Existing } \\
\text { measures were } \\
\text { reviewed, 2) Focus } \\
\text { groups were } \\
\text { conducted with } \\
\text { children and adults, } \\
\text { 3) the measure was } \\
\text { administered to } \\
\text { different groups of } \\
\text { players } \\
\text { Item development } \\
\text { focused on the } \\
\text { participant's } \\
\text { tendency to } \\
\text { become engaged in } \\
\text { violent video games }\end{array}$ \\
\hline Scoring & NR & & NR \\
\hline Readability & NR & $\begin{array}{l}\text { 8th grade (range } \\
\text { across items was } \\
2.2 \text { to } 12 \text { th grade) }\end{array}$ & NR \\
\hline $\begin{array}{l}\text { Sensitivity to } \\
\text { change }\end{array}$ & NR & NR & NR \\
\hline
\end{tabular}




\begin{tabular}{|c|c|c|c|}
\hline Citation & Atkinson, 2007 & $\begin{array}{c}\text { Bakken et al., } \\
2006 \\
\end{array}$ & $\begin{array}{c}\text { Brockmyer, et al., } \\
2009 \\
\end{array}$ \\
\hline $\begin{array}{l}\text { Reliability: } \\
\text { test-retest }\end{array}$ & NR & NR & $x^{2}-c_{1}$ \\
\hline $\begin{array}{l}\text { Reliability: } \\
\text { inter- rater }\end{array}$ & NR & NR & NR \\
\hline $\begin{array}{l}\text { Reliability: } \\
\text { internal } \\
\text { consistency }\end{array}$ & $\begin{array}{l}\text { Items with } \\
\text { Cronbach's alpha } \\
\geq 0.70 \text { retained }\end{array}$ & $\begin{array}{l}\text { Video Visits } \\
\text { Cronbach's alpha } \\
0.96 ; 0.92 \text { for Use } \\
\text { \& Impact }\end{array}$ & NR \\
\hline $\begin{array}{l}\text { Validity: } \\
\text { content }\end{array}$ & NR & $\begin{array}{l}\text { Review by four } \\
\text { telemedicine } \\
\text { experts }\end{array}$ & $\begin{array}{l}\text { Reviewed existing } \\
\text { measures of related } \\
\text { constructs and } \\
\text { conducted focus } \\
\text { groups for item } \\
\text { construction. }\end{array}$ \\
\hline $\begin{array}{l}\text { Validity: } \\
\text { criterion, } \\
\text { convergent, } \\
\text { concurrent, } \\
\text { discriminant }\end{array}$ & NR & $\begin{array}{l}\text { Significant } \\
\text { discriminant validity } \\
\text { between Hispanics } \\
\text { and non- Hispanics }\end{array}$ & NR \\
\hline $\begin{array}{l}\text { Validity: } \\
\text { construct }\end{array}$ & $\begin{array}{l}\text { Confirmatory and } \\
\text { exploratory } \\
\text { factor analyses } \\
\text { to evaluate a } \\
\text { priori scales } \\
\text { consistent with } \\
\text { diffusion of } \\
\text { innovation } \\
\text { framework }\end{array}$ & $\begin{array}{l}\text { Factor analysis } \\
\text { resulted in two } \\
\text { components: Video } \\
\text { Visits and Use \& } \\
\text { Impact }\end{array}$ & NR \\
\hline Sample & College students & $\begin{array}{l}\text { Home based } \\
\text { telemedicine } \\
\text { intervention } \\
\text { participants with } \\
\text { diabetes }\end{array}$ & $\begin{array}{l}\text { Junior high school } \\
\text { students age } \\
12 \text { to } 15 \text { years' } \\
\text { male } \\
\text { undergraduates } \\
\text { attending a } \\
\text { midsized } \\
\text { Midwestern } \\
\text { university }\end{array}$ \\
\hline Limitations & $\begin{array}{l}\text { Use of a } \\
\text { convenience } \\
\text { sample, small } \\
\text { sample size, one } \\
\text { wave of data } \\
\text { collection }\end{array}$ & $\begin{array}{l}\text { Used different } \\
\text { methods of } \\
\text { administration in } \\
\text { subgroups, e.g.,., } \\
\text { mailed surveys vs. } \\
\text { interviews Items } \\
\text { with higher } \\
\text { readability levels } \\
\text { included words such }\end{array}$ & $\begin{array}{l}\text { If expanded to } \\
\text { include non-violent } \\
\text { video games, } \\
\text { additional items } \\
\text { would need to be } \\
\text { included }\end{array}$ \\
\hline
\end{tabular}




\begin{tabular}{|l|l|l|l|}
\hline Citation & Atkinson, 2007 & \multicolumn{1}{|c|}{$\begin{array}{c}\text { Bakken et al., } \\
\mathbf{2 0 0 6}\end{array}$} & $\begin{array}{c}\text { Brockmyer, et al., } \\
\mathbf{2 0 0 9}\end{array}$ \\
\hline & & as telemedicine, & \\
& & blood pressure \\
& testing, blood sugar & \\
& & testing, ADA \\
& educational web \\
& pages, and privacy. & \\
\hline
\end{tabular}

\begin{tabular}{|c|c|c|c|}
\hline Citation & Brooke, 1996 & Bunz, 2004 & $\begin{array}{l}\text { Demiris et el., } \\
2000\end{array}$ \\
\hline $\begin{array}{l}\text { Instrument } \\
\text { name }\end{array}$ & $\begin{array}{l}\text { System Usability } \\
\text { Scale }\end{array}$ & $\begin{array}{l}\text { Computer-email- } \\
\text { web Fluency Scale }\end{array}$ & $\begin{array}{l}\text { Telemedicine } \\
\text { Patient Satisfaction } \\
\text { Questionnaire }\end{array}$ \\
\hline Construct & Usability & $\begin{array}{l}\text { Computer and email } \\
\text { fluency, Web } \\
\text { navigation and } \\
\text { editing }\end{array}$ & $\begin{array}{l}\text { Consumer } \\
\text { perception of the } \\
\text { risks and benefits } \\
\text { of home telecare }\end{array}$ \\
\hline $\begin{array}{l}\text { Theoretical } \\
\text { foundation }\end{array}$ & NR & NR & NR \\
\hline $\begin{array}{l}\text { Modification of } \\
\text { another } \\
\text { instrument }\end{array}$ & NA & Yes & NR \\
\hline \# items & 10 & 21 & 17 \\
\hline Item types & Likert-type & Likert-type & Likert-type \\
\hline $\begin{array}{l}\text { Administration } \\
\text { time }\end{array}$ & NR & NR & NR \\
\hline $\begin{array}{l}\text { Item } \\
\text { development }\end{array}$ & $\begin{array}{l}20 \text { participants } \\
\text { rated two } \\
\text { software systems } \\
\text { (one rated easy } \\
\text { to use, the other } \\
\text { rated difficult to } \\
\text { use) using an } \\
\text { initial pool of } 50 \\
\text { items. } 10 \text { items } \\
\text { that led to the } \\
\text { most extreme } \\
\text { responses were } \\
\text { selected for the } \\
\text { final scale }\end{array}$ & $\begin{array}{l}\text { Original } 46 \text { items- } \\
32 \text { participants } \\
\text { identified confusing } \\
\text { questions and } \\
\text { possible content } \\
\text { areas that were } \\
\text { missing. This } \\
\text { yielded } 52 \text { revised } \\
\text { items then used in } \\
\text { scale development. } \\
\text { Final scale after } \\
\text { reliability and } \\
\text { validity studies } \\
\text { yielded } 21 \text {-item } \\
\text { measure. }\end{array}$ & $\begin{array}{l}\text { Items were } \\
\text { selected from a } \\
\text { review of literature } \\
\text { and focus group } \\
\text { discussions }\end{array}$ \\
\hline
\end{tabular}




\begin{tabular}{|c|c|c|c|}
\hline Citation & Brooke, 1996 & Bunz, 2004 & $\begin{array}{l}\text { Demiris et el., } \\
2000\end{array}$ \\
\hline Scoring & $\begin{array}{l}\text { The score } \\
\text { contribution for } \\
\text { items } 1,3,5,7 \text { and } \\
9 \text { is the scale } \\
\text { position minus } 1 \text {; } \\
\text { the score } \\
\text { contribution for } \\
\text { items } 2,4,6,8 \\
\text { and } 10 \text { is } 5 \text { minus } \\
\text { the scale score. } \\
\text { Scale } \\
\text { contributions are } \\
\text { summed, then } \\
\text { multiplied by } 2.5 \text {; } \\
\text { scores have a } \\
\text { range of } 0 \text { to } \\
100 \text {. }\end{array}$ & $\begin{array}{l}\text { Likert scale item } \\
\text { summed }\end{array}$ & $\begin{array}{l}\text { Responses based } \\
\text { on } 5 \text { - point Likert } \\
\text { scale with overall } \\
\text { scores ranging } \\
\text { from } 17 \text { to } 85 ; \\
\text { higher score } \\
\text { indicates a more } \\
\text { positive patient } \\
\text { perception of } \\
\text { telehomecare. }\end{array}$ \\
\hline Readability & NR & NR & NR \\
\hline $\begin{array}{l}\text { Sensitivity to } \\
\text { change }\end{array}$ & NR & NR & NR \\
\hline $\begin{array}{l}\text { Reliability: } \\
\text { test- retest }\end{array}$ & NR & NR & $\begin{array}{l}\text { The control group } \\
\text { did not have a } \\
\text { statistically } \\
\text { significant change } \\
\text { in overall scores } \\
\text { after a } 30 \text {-day } \\
\text { period (mean } \\
\text { difference }=0.18 \text {, } \\
t=0.69, p=0.51 \text { ). } \\
\text { Also, there was no } \\
\text { significant change } \\
\text { in score for each } \\
\text { item for the pre- } \\
\text { and post-test in the } \\
\text { control group. }\end{array}$ \\
\hline $\begin{array}{l}\text { Reliability: } \\
\text { inter-rater }\end{array}$ & NR & NR & NR \\
\hline $\begin{array}{l}\text { Reliability: } \\
\text { internal } \\
\text { consistency }\end{array}$ & $\begin{array}{l}\text { Intercorrelations } \\
\text { of items ranging } \\
\text { from } \pm 0.7 \text { to } \pm \\
0.9\end{array}$ & $\begin{array}{l}\text { Total scale } \\
\text { coefficient } \\
\text { alpha }=0.89 ; \\
\text { computer subscale= } \\
0.72 \text {. Email } \\
\text { Subscale=0.75, Web } \\
\text { Navigation }=0.64 ., \\
\text { web } \\
\text { editing } 0.79 .\end{array}$ & $\begin{array}{l}\text { Cronbach's alpha } \\
0.8\end{array}$ \\
\hline
\end{tabular}




\begin{tabular}{|c|c|c|c|}
\hline Citation & Brooke, 1996 & Bunz, 2004 & $\begin{array}{l}\text { Demiris et el., } \\
2000\end{array}$ \\
\hline $\begin{array}{l}\text { Validity: } \\
\text { content }\end{array}$ & $\begin{array}{l}\text { Software systems } \\
\text { rated by users in } \\
\text { the scale } \\
\text { development } \\
\text { process were } \\
\text { generally agreed } \\
\text { to be "really easy } \\
\text { to use" or } \\
\text { "almost } \\
\text { impossible to } \\
\text { use." }\end{array}$ & $\begin{array}{l}\text { Reviewed by } \\
\text { students for } \\
\text { question design and } \\
\text { presence or absence } \\
\text { of key concepts. }\end{array}$ & $\begin{array}{l}\text { Results from } 9 \\
\text { focus groups and } \\
\text { feedback from } \\
\text { telemedicine } \\
\text { researchers }\end{array}$ \\
\hline $\begin{array}{l}\text { Validity: } \\
\text { criterion, } \\
\text { convergent, } \\
\text { concurrent, } \\
\text { discriminant } \\
\end{array}$ & 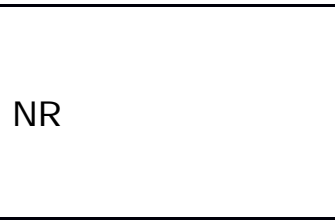 & NR & NR \\
\hline $\begin{array}{l}\text { Validity: } \\
\text { construct }\end{array}$ & $\begin{array}{l}\text { In scale } \\
\text { development, } 10 \\
\text { items (from a } \\
\text { pool of } 50 \text { ) that } \\
\text { elicited the most } \\
\text { extreme } \\
\text { responses when } \\
\text { rating an easy-to- } \\
\text { use and a hard- } \\
\text { to-use software } \\
\text { system of } 50 \\
\text { were selected }\end{array}$ & $\begin{array}{l}\text { Conducted a } \\
\text { principal } \\
\text { component, varimax } \\
\text { rotation, factor } \\
\text { analysis which } \\
\text { yielded four factors: } \\
\text { Basic Computer } \\
\text { Skills, Basic e-Mail } \\
\text { scales, Web } \\
\text { navigation, and Web } \\
\text { editing. Total } \\
\text { percent of variance } \\
\text { accounted for was } \\
67.3 \% \text {. } \\
\text { The CEW showed } \\
\text { adequate } \\
\text { independence from } \\
\text { other measures of } \\
\text { computer use and } \\
\text { satisfaction such as } \\
\text { the Computer Use } \\
\text { Scale, (Panero, } \\
\text { Lane, \& Napier, } \\
\text { 1997) frequency of } \\
\text { use, comfort with } \\
\text { computer use, } \\
\text { number of computer } \\
\text { courses taken. } \\
\text { Duration of Internet } \\
\text { Usage and Level of }\end{array}$ & $\begin{array}{l}\text { High correlation } \\
\text { between similarly } \\
\text { worded items }\end{array}$ \\
\hline
\end{tabular}




\begin{tabular}{|c|c|c|c|}
\hline Citation & Brooke, 1996 & Bunz, 2004 & $\begin{array}{l}\text { Demiris et el., } \\
2000\end{array}$ \\
\hline & & $\begin{array}{l}\text { Expertise predicted } \\
\text { CEW fluency total } \\
\text { score ( } R- \\
\text { square }=0.368)\end{array}$ & \\
\hline Sample & $\begin{array}{l}\text { Office systems } \\
\text { engineering } \\
\text { group }\end{array}$ & College students & $\begin{array}{l}\text { Hospital patients } \\
\text { (and some of their } \\
\text { carers) who were } \\
\text { about to be } \\
\text { discharged } \\
\text { to home care, } \\
\text { home care patients } \\
\text { in assisted-living } \\
\text { facilities and } \\
\text { members of a } \\
\text { cardiac } \\
\text { rehabilitation } \\
\text { support group }\end{array}$ \\
\hline Limitations & $\begin{array}{l}\text { Does not identify } \\
\text { what makes a } \\
\text { system usable (or } \\
\text { not) }\end{array}$ & $\begin{array}{l}\text { Convenience sample } \\
\text { of college students. } \\
\text { Author } \\
\text { acknowledges that } \\
\text { scale might be } \\
\text { improved by } \\
\text { including items with } \\
\text { more advanced } \\
\text { skills. }\end{array}$ & $\begin{array}{l}\text { Sample size; } \\
\text { severity of disease } \\
\text { was not included in } \\
\text { analysis }\end{array}$ \\
\hline
\end{tabular}

\begin{tabular}{|l|l|l|l|}
\hline Citation & $\begin{array}{l}\text { Finkelstein, et } \\
\text { al., } 2012\end{array}$ & $\begin{array}{l}\text { Henkemans et al., } \\
\mathbf{2 0 1 3}\end{array}$ & $\begin{array}{l}\text { Hudiburg, 1989, } \\
\mathbf{1 9 8 9 , 1 9 9 3 , 1 9 9 5}\end{array}$ \\
\hline $\begin{array}{l}\text { Instrument } \\
\text { name }\end{array}$ & No name & $\begin{array}{l}\text { eHealth Analysis } \\
\text { and Steering } \\
\text { Instrument }\end{array}$ & $\begin{array}{l}\text { Computer } \\
\text { Technology Hassles } \\
\text { Scale }\end{array}$ \\
\hline Construct & $\begin{array}{l}\text { Patient } \\
\text { satisfaction }\end{array}$ & $\begin{array}{l}\text { contribute to the } \\
\text { effectiveness of } \\
\text { eHealth supporting } \\
\text { self- management: } \\
\text { 1. Utility 2.Usability } \\
\text { 3. Content }\end{array}$ & $\begin{array}{l}\text { Computer-related } \\
\text { stress independent } \\
\text { of attitudes toward } \\
\text { computer } \\
\text { technology. }\end{array}$ \\
\hline $\begin{array}{l}\text { Theoretical } \\
\text { foundation }\end{array}$ & NR & NR & NR \\
\hline $\begin{array}{l}\text { Modification of } \\
\text { another } \\
\text { instrument }\end{array}$ & NR & NA & NA \\
\hline
\end{tabular}




\begin{tabular}{|c|c|c|c|}
\hline Citation & $\begin{array}{l}\text { Finkelstein, et } \\
\text { al., } 2012 \\
\end{array}$ & $\begin{array}{l}\text { Henkemans et al., } \\
2013\end{array}$ & $\begin{array}{l}\text { Hudiburg, 1989, } \\
1989,1993,1995\end{array}$ \\
\hline \# items & 15 & 32 & 37 \\
\hline I tem types & $\begin{array}{l}\text { Likert-type and } 3 \\
\text { open ended items }\end{array}$ & $\begin{array}{l}\text { Dichotomous items } \\
\text { (applicable, not } \\
\text { applicable) }\end{array}$ & $\begin{array}{l}\text { Severity rating } \\
\text { scale }\end{array}$ \\
\hline $\begin{array}{l}\text { Administration } \\
\text { time }\end{array}$ & NR & NR & NR \\
\hline $\begin{array}{l}\text { I tem } \\
\text { development }\end{array}$ & $\begin{array}{l}\text { Compiled from a } \\
\text { literature review } \\
\text { and other surveys } \\
\text { and item banks }\end{array}$ & $\begin{array}{l}\text { Generated } 43 \text {-items } \\
\text { to reflect the three } \\
\text { concepts described } \\
\text { above. }\end{array}$ & $\begin{array}{l}\text { Patterned after the } \\
\text { Daily Hassles Scale }\end{array}$ \\
\hline Scoring & $\begin{array}{l}\text { Five point Likert } \\
\text { scale; scoring } \\
\text { range } 15 \text { to } 75\end{array}$ & $\begin{array}{l}0 \text { or } 1 \text { for each item } \\
\text { which is summed for } \\
\text { the total score }\end{array}$ & $\begin{array}{l}\text { The number of } \\
\text { hassles endorsed is } \\
\text { counted with a } \\
\text { total score ranging } \\
\text { from } 0 \text { to } 69 \text {. A } \\
\text { second way to } \\
\text { score is deriving a } \\
\text { total severity score } \\
\text { by adding the } \\
\text { severity for all the } \\
\text { items checked, } \\
\text { with a possible } \\
\text { range from } 0 \text { to } \\
207 . \\
\text { The two types of } \\
\text { scoring are highly } \\
\text { correlated. }\end{array}$ \\
\hline Readability & $\begin{array}{l}\text { Sixth grade based } \\
\text { on Flesch-Kincaid } \\
\text { Readability Index } \\
\end{array}$ & NR & NR \\
\hline $\begin{array}{l}\text { Sensitivity to } \\
\text { change }\end{array}$ & NR & $\begin{array}{l}\text { Construct not } \\
\text { expected to change. }\end{array}$ & $\begin{array}{l}\text { Not necessarily } \\
\text { expected to } \\
\text { change. }\end{array}$ \\
\hline $\begin{array}{l}\text { Reliability: } \\
\text { test- retest }\end{array}$ & $\begin{array}{l}\text { Testing } \\
\text { approximately } \\
2.5 \text { months } \\
\text { apart; intra-class } \\
\text { correlation } \\
\text { coefficient was } \\
0.77 \\
\end{array}$ & NR & $\begin{array}{l}\text { Test- } \text { Retest } \\
\text { coefficient = } \\
0.64 \text { over a two- } \\
\text { month time period. }\end{array}$ \\
\hline $\begin{array}{l}\text { Reliability: } \\
\text { inter-rater }\end{array}$ & NR & $\begin{array}{l}\text { Inter-rater reliability } \\
\text { for items ranged } \\
\text { from Kappa }=0.41 \text { to } \\
\text { Kappa= } \\
0.81 . \text { Three items } \\
\text { showed perfect }\end{array}$ & NR \\
\hline
\end{tabular}




\begin{tabular}{|c|c|c|c|}
\hline Citation & $\begin{array}{l}\text { Finkelstein, et } \\
\text { al., } 2012\end{array}$ & $\begin{array}{l}\text { Henkemans et al., } \\
2013\end{array}$ & $\begin{array}{l}\text { Hudiburg, 1989, } \\
1989,1993,1995\end{array}$ \\
\hline & & agreement. & \\
\hline $\begin{array}{l}\text { Reliability: } \\
\text { internal } \\
\text { consistency }\end{array}$ & $\begin{array}{l}\text { Cronbach's alpha } \\
\text { was } \\
0.93 \text { overall }\end{array}$ & $\begin{array}{l}\text { Cronbach's alpha for } \\
\text { three dimensions } \\
\text { ranged between } \\
0.56-0.62 \text {. }\end{array}$ & $\begin{array}{l}\text { Coefficient } \\
\text { alpha=0.95 for the } \\
\text { full scale and } \\
0.94 \text { for the } \\
\text { Computer Runtime } \\
\text { Errors subscale and } \\
0.89 \text { for the } \\
\text { Computer } \\
\text { Information } \\
\text { Problems subscale. }\end{array}$ \\
\hline $\begin{array}{l}\text { Validity: } \\
\text { content }\end{array}$ & $\begin{array}{l}\text { Based on sources } \\
\text { of items, } \\
\text { judgment of } \\
\text { research team, } \\
\text { and informal } \\
\text { discussions with } \\
\text { study participants }\end{array}$ & $\begin{array}{l}\text { Face validity was } \\
\text { tested through a } \\
\text { Delphi process using } \\
\text { Dutch experts. } \\
\text { This process } \\
\text { eliminated } 8 \text { items } \\
\text { and retained } 35 . \\
\text { Both exploratory } \\
\text { and confirmatory } \\
\text { factor analysis } \\
\text { yielded a one- factor } \\
\text { solution. }\end{array}$ & NR \\
\hline $\begin{array}{l}\text { Validity: } \\
\text { criterion, } \\
\text { convergent, } \\
\text { concurrent, } \\
\text { discriminants }\end{array}$ & $\begin{array}{l}\text { Criterion } \\
\text { assessed by } \\
\text { correlation } \\
\text { between actual } \\
\text { home monitoring } \\
\text { adherence and } \\
\text { self-reported } \\
\text { adherence }(0.87)\end{array}$ & $\begin{array}{l}\text { Determined the } \\
\text { degree to which } \\
\text { ratings actually } \\
\text { predicted outcomes } \\
\text { of RCTs that already } \\
\text { occurred. RCT } \\
\text { outcomes were put } \\
\text { in categories: } \\
\text { determinants of } \\
\text { behavior, self- } \\
\text { management } \\
\text { behavior, health } \\
\text { outcomes. } \\
\text { Total eASI predicted } \\
31 \% \text { of the variance } \\
\text { in the effect sizes of } \\
\text { selected RCTs on } \\
\text { self- management } \\
\text { behavior. } \\
\text { Usability and Utility } \\
\text { subscales also } \\
\text { predicted }\end{array}$ & $\begin{array}{l}\text { Computer } \\
\text { Technology Hassles } \\
\text { Scale correlated } \\
\text { positively with the } \\
\text { Perceived Stress } \\
\text { Scale }(r=0.26) \text { but } \\
\text { was not related to } \\
\text { the Computer } \\
\text { Attitude Scale. The } \\
\text { Computer Hassles } \\
\text { Scale correlated } \\
\text { with the Symptom } \\
\text { Checklist - 90 } \\
(r=0.34, p<0.01) \text {. }\end{array}$ \\
\hline
\end{tabular}




\begin{tabular}{|c|c|c|c|}
\hline Citation & $\begin{array}{l}\text { Finkelstein, et } \\
\text { al., } 2012\end{array}$ & $\begin{array}{l}\text { Henkemans et al., } \\
2013\end{array}$ & $\begin{array}{l}\text { Hudiburg, 1989, } \\
1989,1993,1995\end{array}$ \\
\hline & & $\begin{array}{l}\text { effectiveness on } \\
\text { self- management } \\
\text { behavior. Total eASI } \\
\text { score did not predict } \\
\text { effectiveness on } \\
\text { health outcome } \\
\text { measures. Usability } \\
\text { predicted } 13 \% \text { of } \\
\text { the variance on } \\
\text { health outcomes, } \\
\text { but the other two } \\
\text { subscales were not } \\
\text { predictive. }\end{array}$ & \\
\hline $\begin{array}{l}\text { Validity: } \\
\text { construct }\end{array}$ & NR & NR & $\begin{array}{l}\text { Factor analysis } \\
\text { confirmed a four } \\
\text { factor model, in } \\
\text { contrast to the } \\
\text { two-factor model } \\
\text { assumed by the } \\
\text { two subscales. }\end{array}$ \\
\hline Sample & $\begin{array}{l}\text { Patients } \\
\text { participating in } \\
\text { home spirometry } \\
\text { monitoring }\end{array}$ & $\begin{array}{l}7 \text { men and } 9 \text { women } \\
\text { age } \\
20 \text { to } 25 \text { years }\end{array}$ & $\begin{array}{l}\text { College age } \\
\text { students. }\end{array}$ \\
\hline Limitations & $\begin{array}{l}\text { Limited sample } \\
\text { size }\end{array}$ & $\begin{array}{l}\text { Authors } \\
\text { acknowledge the } \\
\text { reliability and } \\
\text { validity could be } \\
\text { improved upon. } \\
\text { They recommend } \\
\text { using a Likert type } \\
\text { of response rather } \\
\text { than dichotomous } \\
\text { ratings. They also } \\
\text { recommend some } \\
\text { content changes for } \\
\text { the items. } \\
\text { Authors state they } \\
\text { have a small sample } \\
\text { of raters and did not } \\
\text { use a large sample } \\
\text { of RCTs. } \\
\text { Moreover, the RCTs } \\
\text { where } \\
\text { predominantly } \\
\text { European. }\end{array}$ & $\begin{array}{l}\text { Needs to be } \\
\text { validated in other } \\
\text { populations; older } \\
\text { instrument }\end{array}$ \\
\hline
\end{tabular}




\begin{tabular}{|c|c|c|c|}
\hline Citation & $\begin{array}{l}\text { Jay \& Willis, } \\
1992\end{array}$ & Lewis, 1995 & Lin, 2011 \\
\hline $\begin{array}{l}\text { Instrument } \\
\text { name }\end{array}$ & No name & $\begin{array}{l}\text { Computer Usability } \\
\text { Satisfaction } \\
\text { Questionnaire }\end{array}$ & No Name \\
\hline Construct & $\begin{array}{l}\text { Seven dimensions } \\
\text { of attitudes } \\
\text { toward } \\
\text { computers: } \\
\text { comfort, efficacy, } \\
\text { gender equality, } \\
\text { control, } \\
\text { dehumanization, } \\
\text { interest, and } \\
\text { utility }\end{array}$ & $\begin{array}{l}\text { User satisfaction } \\
\text { with computer } \\
\text { system usability. }\end{array}$ & $\begin{array}{l}\text { Computer literacy } \\
\text { defined as "basic } \\
\text { computer skills, } \\
\text { whereas computer } \\
\text { competency is } \\
\text { defined as the } \\
\text { computer skills } \\
\text { necessary to } \\
\text { accomplish a job } \\
\text { task." }\end{array}$ \\
\hline $\begin{array}{l}\text { Theoretical } \\
\text { foundation }\end{array}$ & 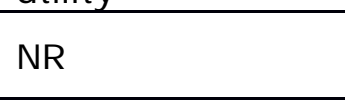 & NR & ( \\
\hline $\begin{array}{l}\text { Modification of } \\
\text { another } \\
\text { instrument }\end{array}$ & NA & NA & NA \\
\hline \# items & 32 & 19 & 22 \\
\hline I tem types & $\begin{array}{l}\text { Likert items } \\
\text { across } 7 \text { factors }\end{array}$ & Likert-type scale & Likert-type \\
\hline $\begin{array}{l}\text { Administration } \\
\text { time }\end{array}$ & NR & NR & NR \\
\hline $\begin{array}{l}\text { I tem } \\
\text { development }\end{array}$ & $\begin{array}{l}\text { Compiled from a } \\
\text { literature review }\end{array}$ & $\begin{array}{l}\text { The PSSUQ, the } \\
\text { measure that } \\
\text { preceded the CSUQ, } \\
\text { was created by IBM } \\
\text { usability experts } \\
\text { using a list of } \\
\text { usability attributes } \\
\text { "known to influence } \\
\text { user perception of } \\
\text { usability.... a series } \\
\text { of investigations } \\
\text { using decision } \\
\text { support systems } \\
\text { revealed a common } \\
\text { set of five system } \\
\text { characteristics } \\
\text { associated with } \\
\text { usability by several } \\
\text { different user } \\
\text { groups." }\end{array}$ & $\begin{array}{l}\text { The scale } \\
\text { developed in this } \\
\text { study is based on } \\
\text { the Ministry of } \\
\text { Education course } \\
\text { guidelines and } \\
\text { relevant literatures } \\
\text { on computer } \\
\text { literacy and } \\
\text { computer } \\
\text { competency." The } \\
\text { researchers } \\
\text { narrowed the } \\
\text { questionnaire to six } \\
\text { constructs } \\
\text { (domains) and } \\
\text { their corresponding } \\
\text { measurement } \\
\text { items based on the } \\
\text { literature. }\end{array}$ \\
\hline Scoring & Factor scores & Average the scores & NR \\
\hline
\end{tabular}




\begin{tabular}{|c|c|c|c|}
\hline Citation & $\begin{array}{l}\text { Jay \& Willis, } \\
1992\end{array}$ & Lewis, 1995 & Lin, 2011 \\
\hline & $\begin{array}{l}\text { calculated for } 7 \\
\text { factors, } \\
\text { standardized to a } \\
\text { mean of } 0 \text { and SD } \\
\text { of } 1\end{array}$ & $\begin{array}{l}\text { from items to obtain } \\
\text { the scale and } \\
\text { subscale scores. } \\
\text { Low scores are } \\
\text { better }\end{array}$ & \\
\hline Readability & $\mathrm{NR}$ & $\mathrm{NR}$ & NR \\
\hline $\begin{array}{l}\text { Sensitivity to } \\
\text { change }\end{array}$ & NR & NR & NR \\
\hline $\begin{array}{l}\text { Reliability: } \\
\text { test- } \\
\text { retest }\end{array}$ & NR & NR & NR \\
\hline $\begin{array}{l}\text { Reliability: } \\
\text { inter- rater }\end{array}$ & NR & NR & NR \\
\hline $\begin{array}{l}\text { Reliability: } \\
\text { internal } \\
\text { consistency }\end{array}$ & $\begin{array}{l}\text { Cronbach's alpha } \\
\text { across } 7 \text { factors } \\
\text { ranged from } .54 \\
\text { to } .82\end{array}$ & $\begin{array}{l}\text { Coefficient alpha } \\
\text { exceeded } 0.89, \\
\text { indicating } \\
\text { acceptable } \\
\text { scale reliability. }\end{array}$ & $\begin{array}{l}\text { Cronbach's alpha } \\
\text { values for the six } \\
\text { constructs were } \\
.828, .867, .932, \\
.838, .894, \text { and } \\
.848, \text { respectively; } \\
\text { overall scale } \\
\text { reliability was } .923\end{array}$ \\
\hline $\begin{array}{l}\text { Validity: } \\
\text { content }\end{array}$ & $\begin{array}{l}\text { 7-factor structure } \\
\text { developed with } \\
\text { college students } \\
\text { and confirmed in } \\
\text { an elderly sample }\end{array}$ & $\begin{array}{l}\text { Items were } \\
\text { developed by IBM } \\
\text { usability experts } \\
\text { using a list of } \\
\text { usability attributes } \\
\text { known to influence } \\
\text { user perception of } \\
\text { usability. }\end{array}$ & $\begin{array}{l}\text { Eleven experts } \\
\text { reviewed content } \\
\text { relevance; A } \\
\text { content validity } \\
\text { index between . } 6 \\
\text { and .8 was } \\
\text { considered } \\
\text { acceptable but } \\
\text { requiring } \\
\text { modification based } \\
\text { on experts' } \\
\text { suggestions. Of the } \\
24 \text { items, all scored } \\
\text { higher than .82, } \\
\text { except for } \\
\text { Multimedia } \\
\text { question } 3, \text { which } \\
\text { scored .73. } \\
\text { After adjustment of } \\
\text { MM3, this study } \\
\text { had a total of } 24 \\
\text { measurement } \\
\text { items. After an } \\
\text { exploratory factor } \\
\text { analysis, the }\end{array}$ \\
\hline
\end{tabular}




\begin{tabular}{|c|c|c|c|}
\hline Citation & $\begin{array}{l}\text { Jay \& Willis, } \\
1992\end{array}$ & Lewis, 1995 & Lin, 2011 \\
\hline & & & $\begin{array}{l}\text { measure was } \\
\text { narrowed down to } \\
22 \text { items. }\end{array}$ \\
\hline $\begin{array}{l}\text { Validity: } \\
\text { criterion, } \\
\text { convergent, } \\
\text { concurrent, } \\
\text { discriminant }\end{array}$ & NR & NR & $\begin{array}{l}\text { Studied factor } \\
\text { loadings (criterion } \\
>0.7 \text { ), Composite } \\
\text { reliability values } \\
\text { and AVE. Factor } \\
\text { loadings for all } \\
\text { items and CR } \\
\text { values for all } \\
\text { constructs were } \\
\text { above } \\
.7 . \text { Average } \\
\text { variance expected } \\
\text { values for all } \\
\text { constructs were } \\
\text { above .5 (all values } \\
\text { were above } \\
\text { recommended } \\
\text { levels). }\end{array}$ \\
\hline $\begin{array}{l}\text { Validity: } \\
\text { construct }\end{array}$ & NR & NR & NR \\
\hline Sample & $\begin{array}{l}\text { Developed with } \\
\text { college students } \\
\text { and validated in } \\
\text { an elderly sample }\end{array}$ & $\begin{array}{l}\text { Employees of } \\
\text { temporary health } \\
\text { agencies with at } \\
\text { least } 3 \text { months } \\
\text { experience with a } \\
\text { computer }\end{array}$ & $\begin{array}{l}\text { Nursing students, } \\
\text { and Exercise \& } \\
\text { Health Science } \\
\text { department } \\
\text { students; } 79 \% \\
\text { were women. }\end{array}$ \\
\hline Limitations & $\begin{array}{l}73 \% \text { of the } \\
\text { elderly validation } \\
\text { sample were } \\
\text { educated women; } \\
\text { only short term } \\
\text { training effects } \\
\text { were measured } \\
\text { ( } 2 \text { weeks) }\end{array}$ & $\begin{array}{l}\text { The article described } \\
\text { multiple } \\
\text { questionnaires } \\
\text { (e.g.,., PSSUQ, ASQ, } \\
\text { CSUQ) and } \\
\text { concluded that a } \\
\text { limitation with all } \\
\text { the tests were that } \\
\text { the validity } \\
\text { measures were all } \\
\text { concurrent and that } \\
\text { future research } \\
\text { should measure the } \\
\text { predictive validity. } \\
\text { The authors indicate } \\
\text { that further } \\
\text { research should }\end{array}$ & $\begin{array}{l}\text { Needs to be } \\
\text { assessed with other } \\
\text { populations. }\end{array}$ \\
\hline
\end{tabular}




\begin{tabular}{|c|c|c|c|}
\hline Citation & $\begin{array}{l}\text { Jay \& Willis, } \\
1992\end{array}$ & Lewis, 1995 & Lin, 2011 \\
\hline & & $\begin{array}{l}\text { utilize available } \\
\text { scales to construct a } \\
\text { "multi-trait- } \\
\text { multimethod matrix } \\
\text { to investigate } \\
\text { convergent and } \\
\text { discriminant validity } \\
\text { for the construct of } \\
\text { usability." }\end{array}$ & \\
\hline
\end{tabular}

\begin{tabular}{|l|l|l|l|}
\hline Citation & $\begin{array}{l}\text { Pluye et al., } \\
\mathbf{2 0 1 4}\end{array}$ & $\begin{array}{l}\text { Schnall \& Bakken, } \\
\mathbf{2 0 1 1}\end{array}$ & $\begin{array}{l}\text { Tariman et al., } \\
\mathbf{2 0 1 1}\end{array}$ \\
\hline $\begin{array}{l}\text { Instrument } \\
\text { name }\end{array}$ & $\begin{array}{l}\text { Information } \\
\text { Assessment } \\
\text { Method }\end{array}$ & No name & $\begin{array}{l}\text { Acceptability e- } \\
\text { Scale }\end{array}$ \\
\hline $\begin{array}{l}\text { Knowledge } \\
\text { translation } \\
\text { between } \\
\text { information } \\
\text { providers and } \\
\text { consumers }\end{array}$ & $\begin{array}{l}\text { Technology } \\
\text { acceptance }\end{array}$ & $\begin{array}{l}\text { Acceptability of } \\
\text { online assessment } \\
\text { of symptom or } \\
\text { quality of life } \\
\text { screening for } \\
\text { cancer patents }\end{array}$ \\
\hline $\begin{array}{l}\text { Theoretical } \\
\text { foundation }\end{array}$ & $\begin{array}{l}\text { Acquisition } \\
\text { cognition } \\
- \text { Level of } \\
\text { Outcomes Model }\end{array}$ & Technology & NR \\
\hline $\begin{array}{l}\text { Modification of } \\
\text { another } \\
\text { instrument }\end{array}$ & No & NA & Yes \\
\hline \# items & 19 & 9 & 6 \\
\hline Item types & Yes/no & Likert-type scale & Likert-type \\
\hline $\begin{array}{l}\text { Administration } \\
\text { time }\end{array}$ & NR & NR & NR \\
\hline
\end{tabular}




\begin{tabular}{|c|c|c|c|}
\hline Citation & $\begin{array}{l}\text { Pluye et al., } \\
2014\end{array}$ & $\begin{array}{l}\text { Schnall \& Bakken, } \\
2011\end{array}$ & $\begin{array}{l}\text { Tariman et al., } \\
2011\end{array}$ \\
\hline $\begin{array}{l}\text { Item } \\
\text { development }\end{array}$ & $\begin{array}{l}\text { Review of } \\
\text { literature } \\
\text { and prior work } \\
\text { (Pluye et al. Four } \\
\text { levels of } \\
\text { outcomes of } \\
\text { information- } \\
\text { seeking: a mixed } \\
\text { methods study in } \\
\text { primary health } \\
\text { care. } \\
\text { J Am Soc Inf Sci } \\
\text { Tec. } \\
2012 ; 64(1) \text { : } 108- \\
125 . \\
\text { doi: } \\
10.1002 / \text { asi. } 2279 \\
\text { 3) } \\
\text { Interviews with } \\
\text { laypersons } \\
\text { Expert panel } \\
\text { review. }\end{array}$ & $\begin{array}{l}\text { Items were } \\
\text { developed } \\
\text { based on constructs } \\
\text { in the } \\
\text { TAM and adapted } \\
\text { from existing } \\
\text { questionnaires. }\end{array}$ & $\begin{array}{l}\text { Items selected } \\
\text { from the } \\
\text { 10-item post- } \\
\text { survey } \\
\text { patient impression } \\
\text { Form developed by } \\
\text { Carlson et al. } \\
\text { (2001) and by } \\
\text { Taenzer et al. } \\
\text { (1997). }\end{array}$ \\
\hline Scoring & NR & $\begin{array}{l}\text { Responses to } \\
\text { structured survey } \\
\text { items are summed. } \\
\text { Two items are } \\
\text { negatively worded } \\
\text { and reverse coded } \\
\text { so that a higher } \\
\text { score was } \\
\text { associated with } \\
\text { more positive } \\
\text { attitudes towards } \\
\text { the system. }\end{array}$ & $\begin{array}{l}1 \text { to } 5 \text { for each } \\
\text { Likert item; } 80 \% \text { of } \\
\text { total possible score } \\
\text { or higher } \\
\text { considered } \\
\text { "Acceptable"; no } \\
\text { validation of this } \\
\text { threshold provided. }\end{array}$ \\
\hline Readability & NR & NR & $\begin{array}{l}\text { Fifth-grade Level. } \\
\text { No item was more } \\
\text { than } 14 \text { words or } \\
\text { more than } 18 \\
\text { syllables. }\end{array}$ \\
\hline $\begin{array}{l}\text { Sensitivity to } \\
\text { change }\end{array}$ & NR & NR & $\begin{array}{l}\text { Not meant to } \\
\text { assess change. }\end{array}$ \\
\hline $\begin{array}{l}\text { Reliability: } \\
\text { test- } \\
\text { retest }\end{array}$ & NR & NR & NR \\
\hline $\begin{array}{l}\text { Reliability: } \\
\text { internal }\end{array}$ & NR & $\begin{array}{l}\text { (a) Perceived } \\
\text { Usefulness ( } 3 \text { items, }\end{array}$ & $\begin{array}{l}\text { Coefficient alpha }= \\
0.757 ; \text { I tem to }\end{array}$ \\
\hline
\end{tabular}




\begin{tabular}{|c|c|c|c|}
\hline Citation & $\begin{array}{l}\text { Pluye et al., } \\
2014\end{array}$ & $\begin{array}{l}\text { Schnall \& Bakken, } \\
2011\end{array}$ & $\begin{array}{l}\text { Tariman et al., } \\
2011\end{array}$ \\
\hline consistency & & $\begin{array}{l}\text { Cronbach's } \\
\text { alpha=0.91), (b) } \\
\text { Perceived Ease of } \\
\text { Use ( } 3 \text { items, } \\
\text { Cronbach's } \\
\text { alpha=0.89) and (c) } \\
\text { Perceived Barriers } \\
\text { to Use ( } 2 \text { items, } \\
\text { Cronbach's } \\
\text { alpha=0.69). }\end{array}$ & $\begin{array}{l}\text { total scale } \\
\text { correlation: range } \\
0.312-0.715 \text { with } \\
\text { only two below } \\
0.40 \text {. } \\
\text { Coefficient alpha } \\
=0.721 \text {. Item total } \\
\text { scale correlations } \\
\text { ranging from } \\
0.211-0.663 \text { with } \\
\text { only two falling } \\
\text { below } 0.40\end{array}$ \\
\hline $\begin{array}{l}\text { Validity: } \\
\text { content }\end{array}$ & $\begin{array}{l}\text { Review of } \\
\text { literature and } \\
\text { prior work; } \\
\text { Interviews with } \\
\text { laypersons; } \\
\text { Expert panel } \\
\text { review }\end{array}$ & $\begin{array}{l}\text { Extensive review of } \\
\text { the literature }\end{array}$ & NR \\
\hline $\begin{array}{l}\text { Validity: } \\
\text { criterion, } \\
\text { convergent, } \\
\text { concurrent, } \\
\text { discriminant }\end{array}$ & 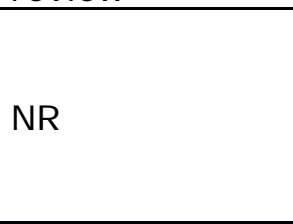 & NR & NR \\
\hline $\begin{array}{l}\text { Validity: } \\
\text { construct }\end{array}$ & NR & $\begin{array}{l}\text { Principal component } \\
\text { factor analysis with } \\
\text { Varimax rotation } \\
\text { ( } n=94 \text { ), sampling } \\
\text { adequacy for factor } \\
\text { analysis assessed } \\
\text { post hoc using the } \\
\text { Kaiser-Meyer-Olkin } \\
\text { (KMO) statistic to } \\
\text { determine if } \\
\text { criterion > } 0.60 \text { was } \\
\text { met. Three factors } \\
\text { explained a total of } \\
84.9 \% \text { of the } \\
\text { variance: (a) } \\
\text { Perceived } \\
\text { Usefulness (b) } \\
\text { Perceived Ease of } \\
\text { Use and (c) } \\
\text { Perceived Barriers } \\
\text { to Use Behavioral } \\
\text { Intention to Use was }\end{array}$ & $\begin{array}{l}\text { Both exploratory } \\
\text { and confirmatory } \\
\text { factor analysis } \\
\text { yielded a one- } \\
\text { factor solution. }\end{array}$ \\
\hline
\end{tabular}




\begin{tabular}{|c|c|c|c|}
\hline Citation & $\begin{array}{l}\text { Pluye et al., } \\
2014\end{array}$ & $\begin{array}{l}\text { Schnall \& Bakken, } \\
2011\end{array}$ & $\begin{array}{l}\text { Tariman et al., } \\
2011\end{array}$ \\
\hline & & $\begin{array}{l}\text { measured through a } \\
\text { single item. }\end{array}$ & \\
\hline Sample & $\begin{array}{l}\text { Laypersons } \\
\text { (health } \\
\text { information } \\
\text { consumers), and } \\
20 \text { experts (co- } \\
\text { authors) from } \\
\text { McGill University, } \\
\text { and } 3 \\
\text { organizational } \\
\text { partners } \\
\text { (Canadian } \\
\text { Pharmacists } \\
\text { Association, } \\
\text { College of Family } \\
\text { Physicians of } \\
\text { Canada, Centre } \\
\text { for Literacy } \\
\text { Québec) }\end{array}$ & $\begin{array}{l}\text { Case managers who } \\
\text { provide care to } \\
\text { persons living with } \\
\text { HIV }\end{array}$ & $\begin{array}{l}\text { Older adults aged } \\
65-90 \text { years }\end{array}$ \\
\hline Limitations & $\begin{array}{l}\text { Lay participants; } \\
\text { convenience } \\
\text { sample with } \\
\text { adequate } \\
\text { functional health } \\
\text { literacy; needs } \\
\text { further validation } \\
\text { with a larger } \\
\text { sample }\end{array}$ & $\begin{array}{l}\text { Selection bias is } \\
\text { possible since all } \\
\text { participants in the } \\
\text { study were Internet } \\
\text { users and willing to } \\
\text { complete and online } \\
\text { survey, and so may } \\
\text { be more likely to } \\
\text { think favorably } \\
\text { about technology. } \\
\text { Respondents } \\
\text { evaluated a mock- } \\
\text { up of a CCR with } \\
\text { context specific } \\
\text { links, rather than } \\
\text { fully functional } \\
\text { systems, and did } \\
\text { not use the system } \\
\text { at the point of care } \\
\text { delivery. }\end{array}$ & $\begin{array}{l}\text { Authors state it } \\
\text { was validated on a } \\
\text { non- diverse } \\
\text { sample that is } \\
\text { relatively well- } \\
\text { educated. }\end{array}$ \\
\hline
\end{tabular}




\begin{tabular}{|c|c|c|c|}
\hline Citation & $\begin{array}{l}\text { Wang \& Wang, } \\
2008\end{array}$ & Wehmeyer, 2008 & $\begin{array}{l}\text { Wolfradt \& Doll, } \\
2001\end{array}$ \\
\hline $\begin{array}{l}\text { Instrument } \\
\text { name }\end{array}$ & $\begin{array}{l}\text { Mobile Computing } \\
\text { Self Efficacy }\end{array}$ & $\begin{array}{l}\text { User-device } \\
\text { Attachment }\end{array}$ & $\begin{array}{l}\text { Internet Motivation } \\
\text { Scale }\end{array}$ \\
\hline Construct & $\begin{array}{l}\text { Mobile computing } \\
\text { self- efficacy } \\
\text { (MCSE) defined } \\
\text { as a summary } \\
\text { judgment of one's } \\
\text { capability to } \\
\text { engage in general } \\
\text { and specific } \\
\text { computing- } \\
\text { related activities } \\
\text { through a mobile } \\
\text { computer. }\end{array}$ & $\begin{array}{l}\text { User-device } \\
\text { attachment }\end{array}$ & $\begin{array}{l}\text { Assesses three } \\
\text { motives: } \\
\text { information, } \\
\text { interpersonal } \\
\text { communication, } \\
\text { and entertainment. }\end{array}$ \\
\hline $\begin{array}{l}\text { Theoretical } \\
\text { foundation }\end{array}$ & $\begin{array}{l}\text { Social cognitive } \\
\text { theory, MCSE can } \\
\text { be a significant } \\
\text { antecedent of } \\
\text { behavioral } \\
\text { intention to use } \\
\text { mobile } \\
\text { computing. }\end{array}$ & $\begin{array}{l}\text { Draws on scholarly } \\
\text { work from } \\
\text { marketing, } \\
\text { sociology, } \\
\text { information science, } \\
\text { and human- } \\
\text { computer } \\
\text { interaction }(\mathrm{HCl}) \text {. }\end{array}$ & NR \\
\hline $\begin{array}{l}\text { Modification of } \\
\text { another } \\
\text { instrument }\end{array}$ & NA & No & NA \\
\hline \# items & $\begin{array}{l}45 \text { items (plus } 6 \\
\text { global items) }\end{array}$ & 19 & 20 \\
\hline I tem types & Likert-type & Likert-type scale & 5-point Likert scale \\
\hline $\begin{array}{l}\text { Administration } \\
\text { time }\end{array}$ & NR & NR & NR \\
\hline $\begin{array}{l}\text { I tem } \\
\text { development }\end{array}$ & $\begin{array}{l}\text { Developed based } \\
\text { on the definition } \\
\text { of MCSE and a } \\
\text { review of the } \\
\text { literature on } \\
\text { computer self- } \\
\text { efficacy, self- } \\
\text { perceived } \\
\text { computer } \\
\text { competence, } \\
\text { network } \\
\text { competence, } \\
\text { web-specific self- } \\
\text { efficacy, and } \\
\text { Internet self- }\end{array}$ & $\begin{array}{l}\text { Developed based on } \\
\text { a review of the } \\
\text { literature for each } \\
\text { domain (symbolism, } \\
\text { aesthetics, and } \\
\text { perceived necessity) } \\
\text { and subsequent } \\
\text { group discussions } \\
\text { with academic staff } \\
\text { and IS and business } \\
\text { students. Reviewed } \\
\text { literature from } \\
\text { marketing on } \\
\text { material possession } \\
\text { attachment, } \mathrm{HCl}\end{array}$ & NR \\
\hline
\end{tabular}




\begin{tabular}{|c|c|c|c|}
\hline Citation & $\begin{array}{l}\text { Wang \& Wang, } \\
2008\end{array}$ & Wehmeyer, 2008 & $\begin{array}{l}\text { Wolfradt \& Doll, } \\
2001\end{array}$ \\
\hline & $\begin{array}{l}\text { efficacy. } \\
\text { Reviewed with } 2 \\
\text { information } \\
\text { system } \\
\text { professionals, two } \\
\text { college teachers, } \\
\text { and three mobile } \\
\text { computer users. }\end{array}$ & $\begin{array}{l}\text { research on the } \\
\text { perception of } \\
\text { aesthetics of } \\
\text { physical and } \\
\text { technical artifacts, } \\
\text { and studies from } \\
\text { sociology on cell } \\
\text { phone usage. }\end{array}$ & \\
\hline Scoring & $\begin{array}{l}\text { Likert scale items } \\
\text { are summed }\end{array}$ & NR & NR \\
\hline Readability & NR & NR & NR \\
\hline $\begin{array}{l}\text { Sensitivity to } \\
\text { change }\end{array}$ & NR & NR & NR \\
\hline $\begin{array}{l}\text { Reliability: } \\
\text { test-retest }\end{array}$ & NR & NR & NR \\
\hline $\begin{array}{l}\text { Reliability: } \\
\text { inter-rater }\end{array}$ & NR & NR & NR \\
\hline $\begin{array}{l}\text { Reliability: } \\
\text { internal } \\
\text { consistency }\end{array}$ & $\begin{array}{l}\text { Cronbach's alpha } \\
\text { for the MCSE } \\
=0.98 \text { (then each } \\
\text { factor: using } \\
\text { basic mobile } \\
\text { computer } \\
\text { operations [.93], } \\
\text { general use of } \\
\text { the Internet } \\
\text { [0.97], using e- } \\
\text { mail } \\
\text { [0.97], using } \\
\text { specific } \\
\text { mobile services } \\
\text { [0.96], } \\
\text { accessing/underst } \\
\text { anding mobile } \\
\text { computer } \\
\text { knowledge [0.94] }\end{array}$ & $\begin{array}{l}\text { Cronbach's alpha } \\
=0.782 \text { for } \\
\text { symbolism, } 0.860 \\
\text { for aesthetics, and } \\
0.857 \text { for necessity. }\end{array}$ & $\begin{array}{l}\text { The internal } \\
\text { consistencies } \\
\text { (alpha) of the } \\
\text { three motives } \\
\text { were: } \\
0.84 \text { for } \\
\text { information; } \\
0.81 \text { for } \\
\text { interpersonal } \\
\text { communication; } \\
\text { and } 0.76 \text { for } \\
\text { entertainment }\end{array}$ \\
\hline $\begin{array}{l}\text { Validity: } \\
\text { content }\end{array}$ & $\begin{array}{l}\text { The authors note } \\
\text { that the rigorous } \\
\text { procedures used } \\
\text { to conceptualize } \\
\text { the construct, } \\
\text { and generate } \\
\text { items } \\
\text { representing the } \\
\text { construct. }\end{array}$ & $\begin{array}{l}\text { Preliminary items } \\
\text { were reviewed with } \\
\text { three expert judges } \\
\text { (researchers in } \\
\text { marketing and IS). }\end{array}$ & NR \\
\hline Validity: & Criterion-related & Convergent validity & Entertainment \\
\hline
\end{tabular}




\begin{tabular}{|c|c|c|c|}
\hline Citation & $\begin{array}{l}\text { Wang \& Wang, } \\
2008\end{array}$ & Wehmeyer, 2008 & $\begin{array}{l}\text { Wolfradt \& Doll, } \\
2001\end{array}$ \\
\hline $\begin{array}{l}\text { criterion, } \\
\text { convergent, } \\
\text { concurrent, } \\
\text { discriminant }\end{array}$ & $\begin{array}{l}\text { validity assessed } \\
\text { by the correlation } \\
\text { between the total } \\
\text { scores on the } \\
\text { MCSE instrument } \\
\text { and the } 6 \text { global } \\
\text { measures of } \\
\text { criterion } \\
\text { (Cronbach's } \\
\text { alpha }=0.966 \text { ); } \\
\text { criterion- related } \\
\text { validity }=0.83 \text {, } \\
\text { p }<0.001 \\
\text { Nomological } \\
\text { validity evaluated } \\
\text { by testing the } \\
\text { hypothesis that } \\
\text { there is a positive } \\
\text { correlation } \\
\text { between the } \\
\text { MCSE score and } \\
\text { the intention to } \\
\text { use mobile } \\
\text { computing } \\
\text { ( } r=0.588 \text {, } \\
p<0.001 \text { ) }\end{array}$ & $\begin{array}{l}\text { ranged from } 0.27 \text { to } \\
0.50 \text { suggesting that } \\
\text { the factors are not } \\
\text { orthogonal. } \\
\text { Discriminant validity } \\
\text { demonstrated by } \\
\text { correlations not } \\
\text { equal or close to } \\
1.00 \text { and low cross- } \\
\text { loadings in the } \\
\text { inter-subscale } \\
\text { correlations. }\end{array}$ & $\begin{array}{l}\text { motive was } \\
\text { positively } \\
\text { associated with } \\
\text { neuroticism and } \\
\text { with all three } \\
\text { personal factors } \\
\text { (attitude, self- } \\
\text { efficacy, } \\
\text { innovativeness) but } \\
\text { unrelated to the } \\
\text { social factors } \\
\text { Interpersonal } \\
\text { communication } \\
\text { motive is positively } \\
\text { related to } \\
\text { neuroticism and } \\
\text { extraversion, to } \\
\text { self- efficacy, and } \\
\text { to expectations of } \\
\text { one's peer group to } \\
\text { use the Internet. }\end{array}$ \\
\hline Limitations & $\begin{array}{l}\text { Authors note that } \\
\text { while it can be } \\
\text { used to assess an } \\
\text { individual's self- } \\
\text { efficacy in mobile } \\
\text { computing, a } \\
\text { better way is to } \\
\text { assess norms and } \\
\text { then compare } \\
\text { individual level } \\
\text { with those norms }\end{array}$ & $\begin{array}{l}\text { More work is needed } \\
\text { to corroborate the } \\
\text { initial } \\
\text { conceptualization. } \\
\text { Testing performed } \\
\text { in non- probabilistic } \\
\text { samples may bias } \\
\text { the results and may } \\
\text { not be } \\
\text { generalizable. } \\
\text { Snowball sampling } \\
\text { used for } \\
\text { confirmatory } \\
\text { analysis may lead to } \\
\text { respondent driven } \\
\text { sampling. } \\
\text { Nomological validity } \\
\text { as not been } \\
\text { established yet. } \\
\text { The use of }\end{array}$ & $\begin{array}{l}\text { Needs to be tested } \\
\text { in other } \\
\text { populations }\end{array}$ \\
\hline
\end{tabular}




\begin{tabular}{|l|l|l|l|}
\hline Citation & $\begin{array}{l}\text { Wang \& Wang, } \\
\mathbf{2 0 0 8}\end{array}$ & Wehmeyer, 2008 & $\begin{array}{l}\text { Wolfradt \& Doll, } \\
\mathbf{2 0 0 1}\end{array}$ \\
\hline & & $\begin{array}{l}\text { subjective scales } \\
\text { and self-reports } \\
\text { may inflate } \\
\text { correlations due to } \\
\text { common method } \\
\text { bias. }\end{array}$ & \\
\hline
\end{tabular}

\begin{tabular}{|l|l|l|}
\hline Citation & Xie, et al., 2013 & Yip et al., 2003 \\
\hline $\begin{array}{l}\text { Instrument } \\
\text { name }\end{array}$ & $\begin{array}{l}\text { Health Information Wants } \\
\text { Scale }\end{array}$ & No name \\
\hline Construct & $\begin{array}{l}\text { Patients' preferences for the } \\
\text { (1) amount of information } \\
\text { desired about different } \\
\text { aspects of a health condition } \\
\text { (Information Preference } \\
\text { Scale), and (2) level of } \\
\text { decision- making autonomy } \\
\text { desired across those same } \\
\text { aspects (Decision Making } \\
\text { Preference Scale). }\end{array}$ & Satisfaction with telemedicine \\
\hline $\begin{array}{l}\text { Theoretical } \\
\text { foundation }\end{array}$ & $\begin{array}{l}\text { The Health Information Wants } \\
\text { (HIW) framework }\end{array}$ & NR \\
\hline $\begin{array}{l}\text { Modification of } \\
\text { another } \\
\text { instrument }\end{array}$ & Yes & NR \\
\hline \# items & 21 for each scale & 14 \\
\hline Item types & $\begin{array}{l}\text { Likert-type (for the scales); } \\
\text { multiple choice, open-ended }\end{array}$ & Likert-type \\
\hline $\begin{array}{l}\text { Administration } \\
\text { time }\end{array}$ & 15-45 minutes & NR \\
\hline $\begin{array}{l}\text { Item } \\
\text { development }\end{array}$ & $\begin{array}{l}\text { Previous literature and } \\
\text { author's previous studies }\end{array}$ & Review of literature \\
\hline Scoring & $\begin{array}{l}\text { Calculate subscale scores and } \\
\text { overall dimension scores as } \\
\text { means across relevant items. }\end{array}$ & NR \\
\hline Readability & NR & NR \\
\hline $\begin{array}{l}\text { Sensitivity to } \\
\text { change }\end{array}$ & NR \\
test-retest & NR \\
\hline $\begin{array}{l}\text { Reliability: } \\
\text { inter- rater } \\
\text { internal }\end{array}$ & $\begin{array}{l}\text { Cronbach alpha coefficients } \\
\text { ranged from .95-.71 for the }\end{array}$ & $\begin{array}{l}\text { Internal consistency 0.93 (did } \\
\text { not specify Cronbach's alpha); }\end{array}$ \\
\hline
\end{tabular}




\begin{tabular}{|c|c|c|}
\hline Citation & Xie, et al., 2013 & Yip et al., 2003 \\
\hline consistency & $\begin{array}{l}\text { younger age group, and .98- } \\
.78 \text { for the older age group }\end{array}$ & $\begin{array}{l}\text { item total correlation }>0.3 \text {; } \\
\text { intraclass correlation } \\
\text { coefficient } 0.43\end{array}$ \\
\hline $\begin{array}{l}\text { Validity: } \\
\text { content }\end{array}$ & NR & $\begin{array}{l}\text { Review by } 14 \text { physicians, } \\
\text { nurses, and telemedicine } \\
\text { experts }\end{array}$ \\
\hline $\begin{array}{l}\text { Validity: } \\
\text { criterion, } \\
\text { convergent, } \\
\text { concurrent, } \\
\text { discriminant } \\
\end{array}$ & NR & $\begin{array}{l}\text { Correlation between TSQ and } \\
\text { self-reported adherence } \\
\text { significant }(r=0.45, p<0.05)\end{array}$ \\
\hline $\begin{array}{l}\text { Validity: } \\
\text { construct }\end{array}$ & $\begin{array}{l}\text { Confirmatory factor analysis } \\
\text { supported construct validity }\end{array}$ & $\begin{array}{l}\text { Factor analysis resulted in } 4 \\
\text { factors; one eliminated; } \\
\text { explained } 68 \% \text { of variation }\end{array}$ \\
\hline Sample & $\begin{array}{l}\text { College students; older adults } \\
\text { recruited from senior centers }\end{array}$ & Chinese sample with diabetes \\
\hline Limitations & Convenience sample & $\begin{array}{l}\text { Validated in Chinese sample, } \\
\text { needs further testing in other } \\
\text { populations; needs } \\
\text { convergent and divergent } \\
\text { validity testing }\end{array}$ \\
\hline
\end{tabular}




\section{Appendix C: Provider Questionnaire}

Overview

To establish a baseline of the usefulness of and barriers in advance care planning, I am conducting a brief research survey in efforts to gather primary opinion from users who are directly related to care planning and are accessing the directives. This brief 11 question survey is voluntary and should take no more than 10 minutes to complete. Your responses are anonymous, there is no way for me to know

who filled out a survey. Feel free to skip any questions that you do not want to answer. If you have questions about the survey, please feel free to email me at rickardd@health.missouri.edu or the Health Sciences IRB Office at irb@missouri.edu.

Please select your occupation

(Select up to two)

$\square$ Chaplain

$\square$ Clinical Ethicist

Nurse (i.e. administrator, RN, LPN)

Physician (i.e. attending, fellow, resident)

Social Worker

Other Health Care Provider (i.e. OT, PT, Medical Assistant)

Other, not listed, please describe

In my role, I have the opportunity (or have in the past) to assist patients with creating an Advance Care Directive:

(Select One)

The above statement is true

The above statement is false.

Please rank how comfortable you are (or would be) assisting a patient in creating or modifying their Advance Care Directive:

(Select One)

Very comfortable

Somewhat comfortable

Somewhat uncomfortable

Very uncomfortable 


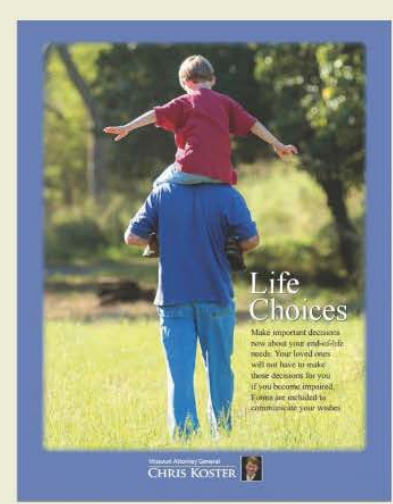

I am familiar with the "Life Choices" book (pictured) which is available to help patients complete an Advance Care Directive:

(Select One)
Very familiar
Somewhat familiar
Somewhat unfamiliar
Not familiar

In your role, do you see Durable Power of Attorney (DPOA) documents more/less/equal to Advance Care Directives in the electronic medical record (EMR)?

(Select One)

I see Durable Power of Attorney documents more frequently in the EMR

I see Advance Care Directive documents more frequently in the EMR.

I see both documents equally in the EMR.

I have never seen either document in the EMR.

In my role, the Advance Care Directive forms I generally see are:

(Select One)

Too specific

Too vague

Contains an appropriate amount of detail

Depends on the situation

I do not see Advance Care Directives

In my role, the length of the Advance Care Directive forms I generally see are: (Select One) 

$\checkmark$ Too short
Too long
The appropriate length
Depends on the situation
I do not see Advance Care Directives

In the EMR, the place (commonly under "Administrative Documents") the Advance Care Directive is stored is: (Select One)

Easy to locate and access

Somewhat easy to locate and access

Not easy to locate and access

Have you ever experienced barriers when utilizing (or attempting to utilize) an Advance Care Directive? (Select One)

Yes, I have experienced barriers.

No, I have not experienced barriers

I have never utilized the EMR to access Advance Care Directives

Please select how often you have experienced the below barriers to proper review and utilization of the current Advance Care Directive form.

(Additional barriers not listed may be entered and ranked via the "Other, please describe" item boxes below)

Applicability of Advance Care Directive wishes to the patient's current clinical presentation

Cannot locate document in the EMR

Difficult to read due to poor handwriting

Difficulty advocating wishes to care team

Difficulty opening scanned document in EMR

Difficulty translating wishes into care plan

Family/Guardian/Spokesperson conflict with the Advance Care Directive

wishes

Missing/incorrect date

Missing notary authentication

Missing witness signatures

I am uncomfortable proceeding with the patients wishes, as written, in the Advance Care Directive

Incomplete document

Inconsistent

Outdated

Outside records (i.e. nursing home records) are not included in the UMHS EMR

$\begin{array}{cccc}\text { Always } & \text { Sometimes } & \text { Rarely } & \text { Never } \\ 0 & 0 & 0 & 0 \\ 0 & 0 & 0 & 0 \\ 0 & 0 & 0 & 0 \\ 0 & 0 & 0 & 0 \\ 0 & 0 & 0 & 0 \\ 0 & 0 & 0 & 0 \\ 0 & 0 & 0 & 0 \\ 0 & 0 & 0 & 0 \\ 0 & 0 & 0 & 0 \\ 0 & 0 & 0 & 0 \\ 0 & 0 & 0 & 0 \\ 0 & 0 & 0 & 0 \\ 0 & 0 & 0 & 0 \\ 0 & 0 & 0 & 0 \\ 0 & 0 & 0 & 0\end{array}$


Pages are missing in the scanned document in the EMR

Physician/team is uncomfortable following the wishes, as written, in the Advance Care Directive

Poor quality of the scanned document

Wishes are difficult to interpret

Other, please describe below:

Other, please describe below:

Other, please describe below:

Other, please describe below:

Other, please describe below:

\begin{tabular}{|llll}
0 & 0 & 0 & 0 \\
0 & 0 & 0 & 0 \\
0 & 0 & 0 & 0 \\
0 & 0 & 0 & 0 \\
0 & 0 & 0 & 0 \\
0 & 0 & 0 & 0 \\
0 & 0 & 0 & 0 \\
0 & 0 & 0 & 0 \\
0 & 0 & 0 & 0
\end{tabular}

Please prioritize improvement areas, as you see them, in the Advance Care Directive process by dragging each item into the prioritization level you select:

(Additional priorities not listed may be entered and ranked via the "Other, please describe" item boxes below)

\section{Items}

A computerized program to

guide patients/users through the advance care planning process.

EMR to require review/approval of any uploaded Advance Care Directive by treating provider.

General population education on advance care planning.

Improved workflow/ownership of patient education with end-of-life medical decision-making.

New location in the EMR to store the Advance Care Directive.

Patients ability to upload their own Advance Care Directive and/or Durable Power of Attorney documents directly to

their medical record.

Process development to improve adherence to Advance Care Directives.

Provider education/training on completion of the Advance Care Directive.

Provider education/training on end of life discussions with patients and/or surrogates.

Provider education/training on futility/breaking bad news.

Provider education/training on surrogacy decision-making and guardianship.

Removal of the notary seal and/or witness signature

requirement to increase ease of adoption.

Review and revise the current hospital policy on Advance Care Directives.

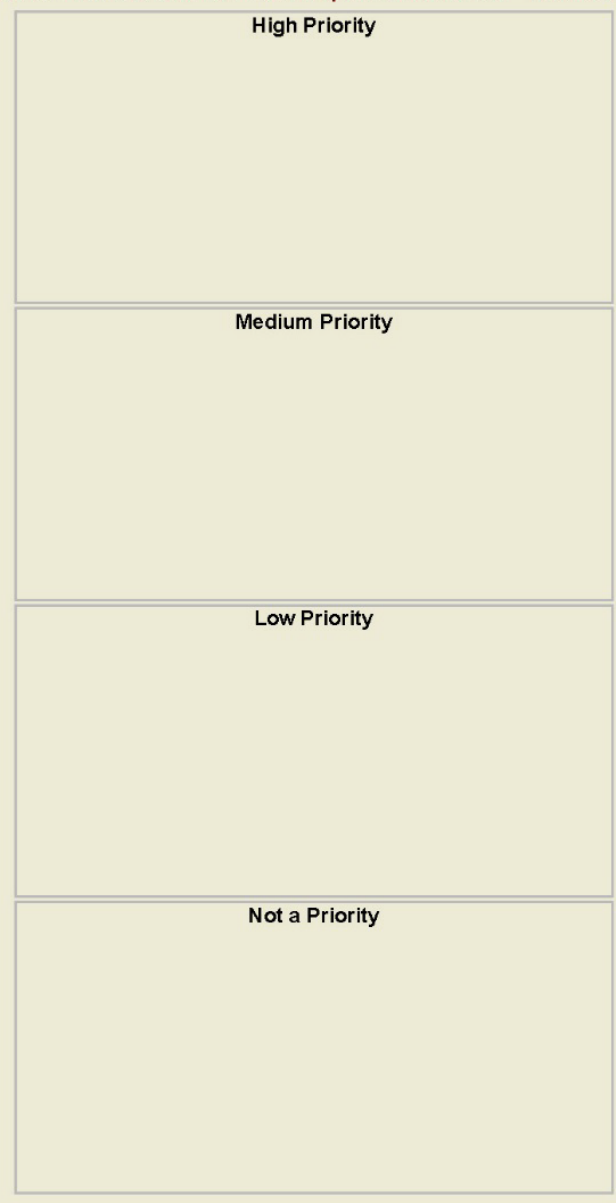




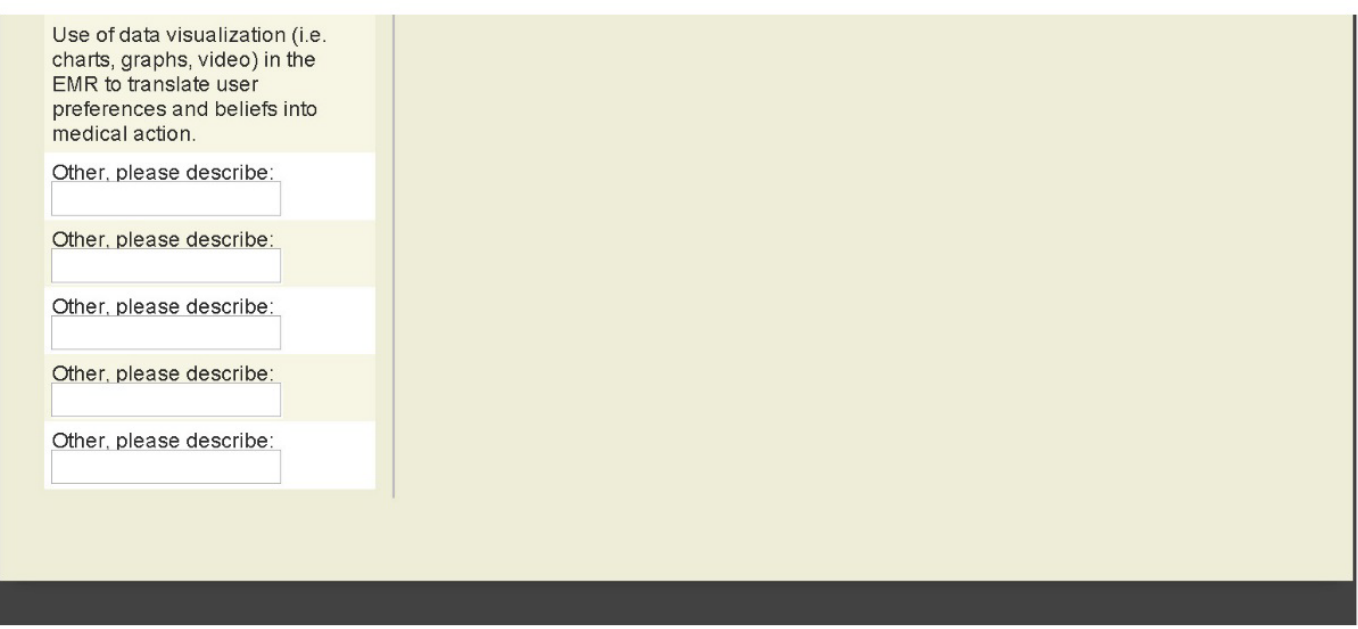




\title{
Appendix D: Consent and Recruitment Email for "Providers Survey on Advance Care Directives" Survey
}

\author{
Consent \& Recruitment Email for “Providers Survey on Advance Care \\ Directives" survey \\ Internet Survey - Message to Supervisors/Leaders/Chairs
}

\begin{abstract}
Good <morning/afternoon>,
To establish a baseline of the usefulness of and barriers in advance care planning, I am conducting a brief research survey to gather primary opinion from users who are directly related to care planning and/or are accessing advance care directives. The purpose of this survey is to establish a baseline of satisfaction and usability, among care providers, with the current advance care planning process and documentation. We ask for your support by forwarding the below invitation to your <social workers, nursing staff, and physicians (including residents and fellows> who are attached to the palliative care, critical care, ICU, internal medicine, or family medicine services and/or work with patients making end-of-life care plans.
\end{abstract}

This brief 11 question survey is voluntary and should take no more than 10 minutes to complete. Your responses are anonymous, there is no way for me to know who filled out a survey. Feel free to skip any questions that you do not want to answer. If you have questions about the survey, please feel free to email me at rickardd@health.missouri.edu or the Health Sciences IRB Office atirb@missouri.edu. If you choose to participate, please click the following link to begin the survey: https://missouri.qualtrics.com/SE/?SID=SV bfJ6VeMH2B6RWhT. Please respond no later than <insert future +30 days $>$.

Thank you in advance for your time and participation.

Sincerely,

Diana Rickard

Doctoral Research Fellow, MU Center for Health Ethics 


\section{Appendix E: Institutional Review Board Approval}

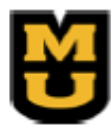

Institutional Review Board

University of Missouri-Columbia
190 Galena Hall; Dc074.00

Columbia, MO 65212

573-882-3181

irb@missouri.edu

October 19, 2015

Principal Investigator: Diana Elizabeth Rickard

Department: Health Mgmt \& Informatics

Your Exempt Application to project entitled Providers Survey on Advance Care Directives was reviewed and approved by the MU Institutional Review Board according to terms and conditions described below:

$\begin{array}{ll}\text { IRB Project Number } & 2003242 \\ \text { IRB Review Number } & 206964 \\ \text { Initial Application Approval Date October 19, } 2015 \\ \text { IRB Expiration Date } & \text { October 19, 2016 } \\ \text { Level of Review } & \text { Exempt } \\ \text { Project Status } & \text { Active - Open to Enrollment } \\ \text { Exempt Categories } & 45 \text { CFR 46.101b(2) } \\ \text { Risk Level } & \text { Minimal Risk } \\ \text { Internal Funding } & \text { Departmental Funding }\end{array}$

The principal investigator (PI) is responsible for all aspects and conduct of this study. The PI must comply with the following conditions of the approval:

1. No subjects may be involved in any study procedure prior to the IRB approval date or after the expiration date.

2. All unanticipated problems, adverse events, and deviations must be reported to the IRB within 5 days.

3. All changes must be IRB approved prior to implementation unless they are intended to reduce immediate risk.

4. All recruitment materials and methods must be approved by the IRB prior to being used.

5. The Annual Exempt Form must be submitted to the IRB for review and approval at least 30 days prior to the project expiration date. If the study is complete, the Completion/Withdrawal Form may be submitted in lieu of the Annual Exempt Form

6. Maintain all research records for a period of seven years from the project completion date.

7. Utilize all approved research documents located within the attached files section of eCompliance. These documents are highlighted green.

If you have any questions, please contact the IRB at 573-882-3181 or irb $\oplus$ missouri.edu. 


\section{BI BLI OGRAPHY}

Ahern D, Kreslake J, Phalen J. What is eHealth (6): perspectives on the evolution of eHealth research. J Med Internet Res 2006 Mar $31 ; 8(1): \mathrm{e} 4$.

Alexander G, Staggers N. A systematic review of the designs of clinical technology: findings and recommendations for future research. Adv Nurs Sci 2009; 32(3):252-279.

Alexander M. Lead or Lag: Linking Strategic Project Management \& Thought Leadership: Lead-Her-Ship Group; 2016.

American Bar Association. Health Care Advance Directives- What is the Patient Self-Determination Act? n.d.

American Heart Association. Highlights of the History of Cardiopulmonary Resuscitation (CPR) 2006 [Available from: www.americanheart.org.

Ammerman R, Putnam F, Kopke J, Gannon T, Short J, et al. 2007. Development and implementation of a quality assurance infrastructure in a multisite home visitation program in ohio and kentucky. J Prev Intervent Community. 34(1-2), 89-107.

Anderson T. The theory and practice of online learning: Athabasca University Press; 2008 
Annas G. Nancy Cruzan and the right to die. New England J ournal of Medicine. 1990;323(10):670-3.

Atkinson NL. Developing a questionnaire to measure perceived attributes of eHealth innovations. Am J Health Behav $2007 ; 31(6): 612-621$.

Bakken S, Grullon-Figueroa L, Izquierdo R, Lee N, Morin P, Palmas W, IDEATel Consortium. Development, validation, and use of English and Spanish versions of the telemedicine satisfaction and usefulness questionnaire. J Am Med Inform Assoc 2006; 13(6):660667.

Black A, Car J, Pagliari C, Anandan C, Cresswell K, Bokun T, et al. The impact of eHealth on the quality and safety of health care: a systematic overview. PLoS Med 2011;8(1):e1000387.

Blanson Henkemans OA, Dusseldorp E, Keijsers J, Kessens J, Neerincx M, Otten W. Validity and reliability of the eHealth analysis and steering instrument. Med 20 2013;2(2): e8.

Brinkman-Stoppelenburg A, Rietjens J A, van der Heide A. The effects of advance care planning on end-of-life care: A systematic review Palliative Medicine. 2014;28(8): 1000-25. 
Brockmyer J, Fox C, Curtiss K, McBroom E, Burkhart K, Pidruzny J. The development of the Game Engagement Questionnaire: a measure of engagement in video game-playing. J Exp Soc Psychol $2009 ; 45(4): 624-634$.

Brooke J. SUS: a "quick and dirty" usability scale. Usability Evaluation in Industry. 1996.

Brooke J. SUS: a quick and dirty usability scale. In: Jordan P, Thomas B, Weerdmeester B, McClelland I, Bristol P, editors. Usability Evaluation in Industry. London: Taylor \& Francis; 1996: 189-194.

Bunz U. The Computer-Email-Web (CEW) Fluency Scale-development and validation. Int J Hum-Comput Interact 2004; 17(4):479-506.

Calabretta N. Consumer-driven, patient-centered health care in the age of electronic information. J Med Libr Assoc 2002 Jan; 90(1):3237.

Cassel C, Demel B. Remembering death: public policy in the USA. J ournal of the Royal Society of Medicine. 2001;94(9):433-6.

Cella D, Riley W, Stone A, Rothrock N, Reeve B, Yount S, et al. The Patient-Reported Outcomes Measurement Information System (PROMIS) developed and tested its first wave of adult self-reported 
health outcome item banks. J Clin Epidemiol 2010;63(11):11791194.

Cella D, Yount S, Rothrock N, Gershon R, Cook K, Reeve B, et al. The Patient-Reported Outcomes Measurement Information System (PROMIS): progress of an NIH Roadmap cooperative group during its first two years. Med Care 2007; 45(5 Suppl 1):S3-S11.

Centers for Disease Control and Prevention. Deaths and mortality Atlanta, GA. 2016.

Chen C, Garrido T, Chock D, Okawa G, Liang L. The Kaiser Permanente electronic health record: transforming and streamlining modalities of care. Health Affairs 2009;28(2):323-333.

Davis P, Solomon J, Gorenflo G. 2010. Driving quality improvement in local public health practice. J Public Health Manag Pract. 16(1), 6771.

de Jong CC, Ros W, Schrijvers G. The effects on health behavior and health outcomes of Internet-based asynchronous communication between health providers and patients with a chronic condition: a systematic review. J Med Internet Res 2014 Jan 16; 16(1): e19.

Deming W. Out of the Crisis. Cambridge, MA: Massachusetts Institute of Technology Centre for Advanced Engineering Study xiii; 1983. 
Demiris G, Speedie S, Finkelstein S. A questionnaire for the assessment of patients' impressions of the risks and benefits of home telecare. J Telemed Telecare 2000;6(5):278-284.

Elbert N, van Os-Medendorp H, van Renselaar W, Ekeland A, Hakkaartvan $R L$, Raat $H$, et al. Effectiveness and cost-effectiveness of ehealth interventions in somatic diseases: a systematic review of systematic reviews and meta-analyses. J Med Internet Res 2014 Apr 16; 16(4): e110.

Eysenbach G. What is e-health? J Med Internet Res 2001;3(2): e20.

Field MJ , \& Cassel, C. K. Approaching death: improving care at the end of life. Committee on Care at the End of Life. Division of Health Care Services, Institute of Medicine National Academy of Sciences Chicago. 1997.

Finkelstein SM, MacMahon K, Lindgren BR, Robiner WN, Lindquist R, VanWormer A, et al. Development of a remote monitoring satisfaction survey and its use in a clinical trial with lung transplant recipients. J Telemed Telecare 2012; 18(1):42-46.

Ghazisaeidi M, Safdari R, Torabi M, Mirzaee M. 2015. Development of performance dashboards in healthcare sector: key practical issues. Acta Inform Med. 23(5), 317. 
Green MJ, Levi BH. Development of an interactive computer program for advance care planning. Health Expect. 2009;12(1):60-9.

Herlle M, Astray-Caneda V. The Impact of Social Media in the Workplace. 2013:67-73.

Hogan T, Wakefield B, Nazi K, Houston T, Weaver F. Promoting access through complementary eHealth technologies: recommendations for VA's Home Telehealth and personal health record programs. J Gen Intern Med 2011 Nov; 26 Suppl 2:628-635.

Holden RJ, Karsh B. The technology acceptance model: its past and its future in health care. J Biomed Inform 2010 Feb; 43(1): 159-172. Hossler C, Levi BH, Simmons Z, Green MJ. Advance care planning for patients with ALS: feasibility of an interactive computer program. Amyotroph Lateral Scler. 2011;12(3): 172-7.

Hudiburg RA, Ahrens PK, Jones TM. Psychology of computer use: XXXI. Relating computer users' stress, daily hassles, somatic complaints, and anxiety. Psychol Rep 1994 Dec; 75(3 Pt 1): 1183-1186.

Hudiburg RA, Jones TM. Psychology of computer use: XXIII. Validating a measure of computer-related stress. Psychol Rep $1991 ; 69(1): 179-182$. 
Hudiburg RA, Necessary JR. Psychology of computer use: XXXV. Differences in computer users' stress and self-concept in college personnel and students. Psychol Rep 1996 Jun; 78(3 Pt 1):931-937. Hudiburg RA. Psychology of computer use: XXXIV. The Computer Hassles Scale: subscales, norms, and reliability. Psychol Rep 1995 Dec; 77(3 Pt 1):779-782.

Institute of Medicine Committee on Care at the End of Life. Approaching death: improving care at the end of life. Washington, DC; 1997.

Institute of Medicine. Crossing the quality chasm: a new health system for the 21st century. Washington, D.C.: National Academy Press; 2001.

Jay G, Willis S. Influence of direct computer experience on older adults' attitudes toward computers. J Gerontol 1992 Jul; 47(4):P250-P257.

Kass-Bartelmes, B.L. and R. Hughes, Advance care planning. Journal of Pain \& Palliative Care Pharmacotherapy, 2004. 18(1): p. 87-109. Kennedy DR, Boren SA, Kapp JM, Simoes EJ. Building and launching an online quality improvement information exchange for home visiting 
programs in Missouri. Online J ournal of Public Health Informatics. 2017 Sep 8; 9(2).

Kim J, Park HA. Development of a health information technology acceptance model using consumers' health behavior intention. J Med Internet Res 2012 Oct 01; 14(5): e133.

Kirschner K. When written advance directives are not enough. Clinics in Geriatric Medicine. 2005; 21: 193-209.

Klein-Fedyshin MS. Consumer Health Informatics--integrating patients, providers, and professionals online. Med Ref Serv Q 2002;21(3):3550.

Krug S. Don't Make Me Think, Revisited: A Common Sense Approach to Web Usability: New Riders; 2014.

Kutner L. Due Process of Euthanasia: The Living Will, A Proposal. Indiana Law Journal. 1969;44(4).

Lai J, Cella D, Choi S, Junghaenel D, Christodoulou C, Gershon R, et al. How item banks and their application can influence measurement practice in rehabilitation medicine: a PROMIS fatigue item bank example. Arch Phys Med Rehabil 2011;92(10 Suppl):S20-S27. 
Lewis J. IBM computer usability satisfaction questionnaires:

psychometric evaluation and instructions for use. Int J HumComput Int 1995;7(1):57-78.

Lin T. A computer literacy scale for newly enrolled nursing college students: development and validation. J Nurs Res 2011;19(4):305317.

Lockwood NR. 2007. Leveraging employee engagement for competitive advantage. Society for Human Resource Management Research Quarterly. 1, 1-12.

Marchand L, Cloutier VM, Gjerde C, Haq C. Factors influencing rural Wisconsin elders in completing advance directives. WMJ . $2001 ; 100(9): 26-31$.

Martínez-Caro E, Cegarra-Navarro JG, Solano-Lorente M. Understanding patient e-loyalty toward online health care services. Health Care Manage Rev 2013;38(1):61-70.

Medicare Payment Advisory Commission (MedPac). Medicare Payment Policy. Washington, DC; 2014.

Meghani Shea. Policy brief: The Institute of Medicine report Dying in America: Improving quality and honoring individual preferences near the end of life. Nursing Outlook. 2014;63(1):51-9. 
Montague E. Validation of a trust in medical technology instrument. Appl Ergon 2010;41(6):812-821.

Moser R, Hesse B, Shaikh A, Courtney P, Morgan G, Augustson E, et al. Grid-enabled measures: using Science 2.0 to standardize measures and share data. Am J Prev Med 2011;40(5 Suppl 2):S134-S143.

Muthappan P, Forster H, Wendler D. Research Advance Directives: Protection or Obstacle? American Journal of Psychiatry. 2005; 162(12): 2389-91.

Nazi K, Hogan T, Woods S, Simon S, Ralston J. Consumer health informatics: engaging and empowering patients and families. In: Finnell JT, Dixon BE, editors. Clinical Informatics Study Guide: Text and Review. New York: Springer; 2016:459-500.

Norman C, Skinner H. eHealth literacy: essential skills for consumer health in a networked worldw. J Med Internet Res 2006 J un 16;8(2): e9.

Norman CD, Skinner HA. eHEALS: The eHealth Literacy Scale. J Med Internet Res 2006;8(4): e27.

Parry E, Solidoro A. 2013. Social media as a mechanism for engagement. Advanced Series in Management. 12, 121-41. 
Payne PR, Lussier Y, Foraker RE, Embi PJ. Rethinking the role and impact of health information technology: informatics as an interventional discipline. BMC Med Inform Decis Mak. 2016 Mar 29; 16: 40 .

Pew Research Center, Views on end-of-life medical treatments. November 2013.

Pluye P, Granikov V, Bartlett G, Grad R, Tang D, Johnson-Lafleur J, et al. Development and content validation of the information assessment method for patients and consumers. JMIR Res Protoc 2014 Feb 18;3(1):e7.

Pollack KM, Morhaim D, Williams MA. The public's perspectives on advance directives: implications for state legislative and regulatory policy. Health Policy. 2010;96(1):57-63.

Quinlan J. Karen Ann Quinlan. Trends Health Care Law Ethics. 1993; 8:65-8.

Radaideh MDA. Architecture of Reliable Web Applications Software: IGI Global; 2006.

Riley G, Lubitz J. Long-term trends in medicare payments in the last year of life. Health Services Research. 2010;45(2):565-76. 
Rondan-Cataluña FJ, Arenas-Gaitán J, Ramírez-Correa PE. A comparison of the different versions of popular technology acceptance models. Kybernetes 2015; 44(5): 788-805.

Rothrock NE, Hays RD, Spritzer K, Yount SE, Riley W, Cella D. Relative to the general US population, chronic diseases are associated with poorer health-related quality of life as measured by the PatientReported Outcomes Measurement Information System (PROMIS). J Clin Epidemiol 2010 Nov;63(11): 1195-1204.

Sarkar U, Lyles C, Parker M, Allen J, Nguyen R, Moffet H, et al. Use of the refill function through an online patient portal is associated with improved adherence to statins in an integrated health system. Med Care 2014 Mar; 52(3): 194-201.

Sauro J, Kindlund E, eds. A method to standardize usability metrics into a single score. Proceedings of the SIGCHI conference on Human factors in computing systems; 2005: ACM.

Schnall R, Bakken S. Testing the Technology Acceptance Model: HIV case managers' intention to use a continuity of care record with context-specific links. Inform Health Soc Care 2011 Sep; 36(3): 161172. 
Schubart J R, Levi BH, Camacho F, Whitehead M, Farace E, Green MJ . Reliability of an interactive computer program for advance care planning. J Palliat Med. 2012; 15(6):637-42.

Seymour J, Almack K, Kennedy S. Implementing advance care planning: a qualitative study of community nurses' views and experiences. BMS Palliative Care. 2010;9(4).

Seymour J. Technology and "natural death": a study of older people. Zeitschrift fur Gerontologie und Geriatrie. 2003;36(5):339-46.

Singer P, Martin D, Lavery J, Thiel E, Kelner M, Mendelssohn D. Reconceptualizing Advance Care Planning From the Patient's Perspective. Arch Intern Med. 1998; 158(8):879-84.

Sittig $D$, Singh $H$. A new sociotechnical model for studying health information technology in complex adaptive healthcare systems. Qual Saf Health Care 2010 Oct; 19 Suppl 3:i68-i74.

Streiner D, Norman G. Health Measurement Scales: A Practical Guide to Their Development and Use. Oxford: Oxford University Press; 1995.

Sweet M, Appelbaum M. 2004. Is home visiting an effective strategy? A meta-analytic review of home visiting programs for families with young children. Child Dev. 75(5), 1435-56. 
Tang P, Overhage J, Chan A, Brown N, Aghighi B, Entwistle M, et al. Online disease management of diabetes: engaging and motivating patients online with enhanced resources-diabetes (EMPOWER-D), a randomized controlled trial. J Am Med Inform Assoc 2013 May $01 ; 20(3): 526-534$.

Tariman J, Berry D, Halpenny B, Wolpin S, Schepp K. Validation and testing of the Acceptability E-scale for web-based patient-reported outcomes in cancer care. Appl Nurs Res 2011 Feb;24(1):53-58.

Thompson T, Barbour R, Schwartz L. Adherence to advance directives in critical care decision making: vignette study2003 2003-10-30 10:26: 14. $1011 \mathrm{p}$.

U.S. Census Bureau PD. 2012 National Population Projections: Summary Tables, Projections of the population by age and sex for the United States: 2015 to 2060 (NP2012-T12). 2012.

U.S. Census Bureau PD. Annual Estimates of the Resident Population by Sex and Five-Year Age Group for the United States: April 1, 2010 to J uly 1, 2011 (NC-EST2011-01). 2011.

U.S. Department of Health and Human Services Health Resources and Services Administration. Quality Improvement. n.d. Available from: 
http://www.hrsa.gov/quality/toolbox/methodology/qualityimprovem

ent/

Venkatesh V, Bala H. Technology Acceptance Model 3 and a research agenda on interventions. Decision Sci 2008;39(2):273-315.

Wakefield BJ, Turvey CL, Nazi KM, Holman JE, Hogan TP, Shimada SL, Kennedy DR. Psychometric Properties of Patient-Facing eHealth Evaluation Measures: Systematic Review and Analysis. Journal of Medical Internet Research. 2017 Oct; 19(10).

Wang Y, Wang H. Developing and validating an instrument for measuring mobile computing self-efficacy. Cyberpsychol Behav $2008 ; 11(4): 405-413$.

Wehmeyer K. User-device attachment scale: development and initial test. Int J Mob Commun 2008;6(3):280-295.

White B, Tilse C, Wilson J, Rosenman L, Strub T, Feeney R, et al. Prevalence and predictors of advance directives in Australia. Internal Medicine Journal. 2014;44(10):975-80.

Wolfradt U, Doll J. Motives of adolescents to use the internet as a function of personality traits, personal and social factors. J Educ Comput Res 2001;24(1):13-27. 
Woolrych A, Cockton G, eds. Why and when five test users aren't enough. IHM-HCl 2001 conference; 2001; Toulouse, FR.

Xie B, Wang M, Feldman R, Zhou L. Internet use frequency and patient-centered care: measuring patient preferences for participation using the health information wants questionnaire. J Med Internet Res 2013; 15(7): e132.

Yip M, Chang A, Chan J, MacKenzie A. Development of the Telemedicine Satisfaction Questionnaire to evaluate patient satisfaction with telemedicine: a preliminary study. J Telemed Telecare 2003; 9(1):46-50.

Yost KJ, Eton DT, Garcia SF, Cella D. Minimally important differences were estimated for six Patient-Reported Outcomes Measurement Information System-Cancer scales in advanced-stage cancer patients. J Clin Epidemiol 2011 May;64(5):507-516. 


\section{VITA}

Diana Kennedy received a Bachelor of Arts degree in human services from Columbia College in 2010, a Master of Science degree in health informatics and bioinformatics, and a Master of Health Administration from the University of Missouri in 2015. She is currently pursuing a Doctorate of Philosophy degree in health informatics at the University of Missouri. She is Associate Director of Program/Project Operations for the Department of Health Management and Informatics at the University of Missouri-Columbia, School of Medicine. Her research interests include human-computer interaction, computer assisted instruction, quality improvement, and population-based advance care planning utility. 